\title{
Kinetic Modeling of Nonmetallic Inclusions Behavior in Molten Steel: A Review
}

\begin{abstract}
JOO HYUN PARK and LIFENG ZHANG
The kinetic modeling for the nucleation, size growth, and compositional evolution of nonmetallic inclusions in steel was extensively reviewed in the present article. The nucleation and initial growth of inclusion in molten steel during deoxidation as well as the collision growth, motion, removal, and entrapment of inclusions in the molten steel in continuous casting (CC) tundish and strand were discussed. Moreover, the recent studies on the prediction of inclusion composition in CC semiproducts were introduced. Since the 1990s, the development of thermodynamic model and relevant databases for inclusion engineering has been initiated by the steel industry. Later, the commercial software FACTSAGE employing the FACT database was widely used to predict the gas (atmosphere/bubble)-liquid (steel/slag/inclusion)-solid (refractory/slag/steel/inclusion) multiphase equilibria. With the help of the comprehensive thermodynamic database and solution models in conjunction with the development of user-friendly computing packages, the kinetics of inclusion evolution in molten steel can be successfully predicted based on several kinetic models such as the coupled reaction (CR) model, reaction zone model, and tank series recirculation (TSR) model. However, some parameters are needed to represent the real processes according to the model employed at different operational or experimental conditions. The effect of reoxidation on the evolution of inclusions in the ladle and tundish, which was experimentally confirmed, can be simulated by the effective equilibrium reaction zone (EERZ) model. The complex slag-steel interfacial reaction phenomena have been successfully explained by the interfacial kinetic model based on the dynamic interfacial tension and oxygen adsorption/desorption characteristics at the slag-steel interface.
\end{abstract}

https://doi.org/10.1007/s11663-020-01954-1

(C) The Minerals, Metals \& Materials Society and ASM International 2020

\section{INTRODUCTION}

HIGH-QUALITY steels require an optimized control of nonmetallic inclusions that are the inevitable product of the carbon-based ironmaking and steelmaking process and the complicated composition of steels. As long as carbon materials are used as the reducer to replace the oxygen from the iron mineral ores, carbon enters the hot metal and oxygen gas has to be injected into the hot metal to react away the excess carbon, from

JOO HYUN PARK is with the Department of Materials Science and Chemical Engineering, Hanyang University, Ansan 15588, Korea and also with the Department of Materials Science and Engineering, KTH Royal Institute of Technology, Stockholm 100 44, Sweden. Contact e-mail: basicity@hanyang.ac.kr LIFENG ZHANG is with the State Key Laboratory of Metastable Materials Science and Technology, Yanshan University, 438 West Hebei Avenue, Qinhuangdao 066004, P.R. China. Contact e-mail: zhanglifeng@ysu.edu.cn

Manuscript submitted March 23, 2020.

Article published online October 14, 2020. which iron is converted into steel. The dissolved oxygen remaining in the molten steel after oxygen injection had to be removed by deoxidizer metals, such as aluminum, silicon, and manganese, so that the indigenous nonmetallic oxide inclusions generated. Furthermore, the metallic elements added to the molten steel naturally react with the oxygen if they are more active than iron. Hence, inclusions in steel never hold one single component and always are compound mixtures, and it is impossible to remove all inclusions from the steel due to their instinct sources. There also are exogenous inclusions in the molten steel from slag entrainment, erosion of lining refractory, and reoxidation from air absorption. The ideal task for the control of inclusions in the steel is to remove the detrimental ones, especially big ones, and to utilize the useful ones, especially small ones with desired composition, as well as possible.

Figure 1 shows the entire life of inclusion in the steel. ${ }^{[1]}$ The indigenous inclusions start from the addition of the deoxidizer into the molten steel. Once aluminum, as an example of deoxidizer metal, is added into the molten steel, with the dissolution of the aluminum, the dissolved 


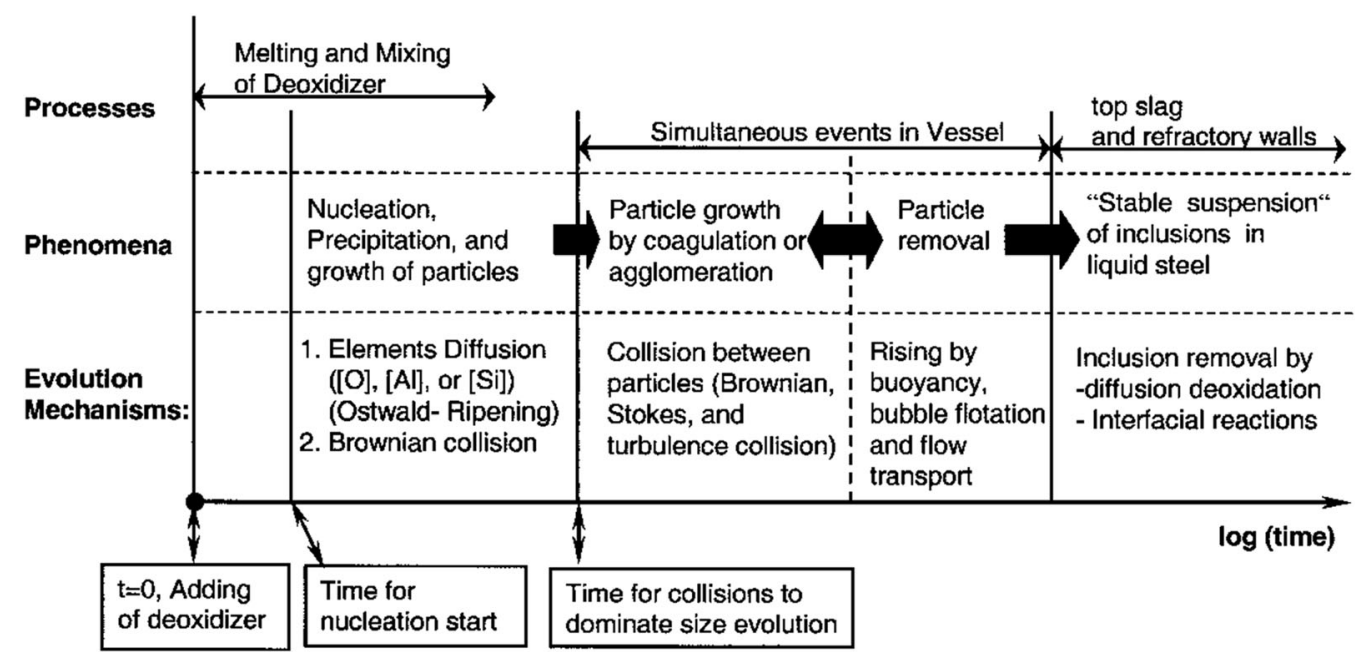

Fig. 1-Schematic of the generation of inclusions and relevant phenomena in the steel. Reprinted from Ref. [1].
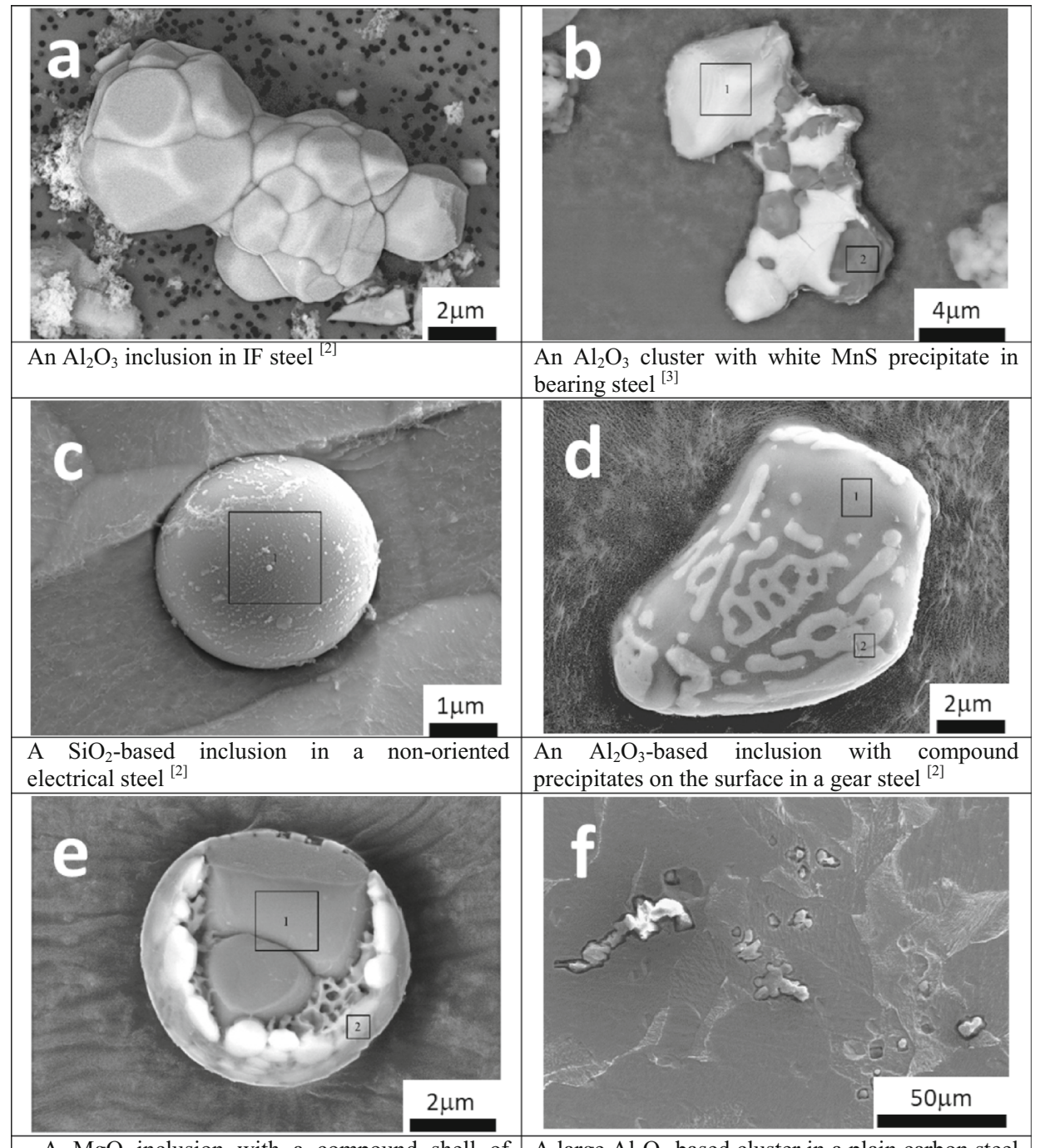

A $\mathrm{MgO}$ inclusion with a compound shell of $\mathrm{A}$ large $\mathrm{Al}_{2} \mathrm{O}_{3}$-based cluster in a plain carbon steel oxide and sulfide in a spring steel ${ }^{[3]}$ matrix ${ }^{[2]}$

Fig. 2-Typical 3-D morphology of inclusions in steels. The detailed description of each inclusion type from $(a)$ through $(f)$ is included in each figure box. Reprinted with permission from Refs. [2 and 3]. 
Table I. Publications on Inclusions Behavior in Several Agendas

\begin{tabular}{lc}
\hline Aspects on Inclusions in Steel & References \\
\hline Extensive Review & $4-9$ \\
Academic Books & $2,3,10-17$ \\
Detection of Inclusions & $7,18-22$ \\
Morphology of Inclusions & $23-39$ \\
Nucleation, Collision, and Growth of Inclusions & $40-70$ \\
Thermodynamics for the Formation and Transformation of Inclusions & $26,71-96$ \\
Kinetics in the Size and Composition of Inclusions & $97-113$ \\
Interfacial Phenomena: Bubble and Inclusion & $114-124$ \\
Fluid Flow and Inclusion Removal in Metallurgical Vessels & $52,125-139$ \\
Prediction of Inclusions in Casting Products & $74,111,140-144$ \\
Transformation of Inclusions in Solid Steel & $95,104,105,145-151$ \\
Deformation of Inclusions in Steel During Rolling & $152-157$ \\
Calcium Treatment & $74,158-173$ \\
Dependency of Steel Properties on Inclusions & $9,12,15,83,174-205$ \\
\hline
\end{tabular}

oxygen reacts with the dissolved aluminum and pseudomolecules of alumina generated, with a size of $<0.3 \mathrm{~nm}$. A group of pseudo-molecules form by the fluctuation of concentration of aluminum and oxygen and fluctuation of temperature, and if the size of the group is larger than the critical size of nucleation, the group of pseudo-molecules precipitate as a real particle - an inclusion. The preceding process is controlled by the diffusion of the dissolved elements in the molten steel, called Ostwald ripening. After precipitating, inclusions grow by collision and diffusion as well.

The morphology of inclusions depends mainly on their composition and the subsequent precipitation in the solid steel during the cooling, heating, and rolling process. As shown in Figure $2{ }^{[2,3]}$ inclusions can be sintered ones (Figures 2(a) and (b)), single spherical ones (Figure 2(c)), or irregular ones (Figure 2(d)); can oxide with an outer precipitated layer (Figure 2(e)); or can be a cluster as large as several hundred micrometers (Figure 2(f)).

During the refining and casting process, inclusions continue to grow, move, and are removed from the molten steel through flow transport, bubble floatation to the top slag. During the continuous casting (CC) process, the molten steel in the ladle flows into the tundish and then exits down through a ceramic submerged entry nozzle and enters the mold. Inclusions in the molten steel either flow up to the top flux to remove or move with the flow deeply into the strand and are captured by the solidification front and become defects in the steel. The interfacial phenomena between inclusion and inclusion, between inclusion and bubble, and between inclusion and slag/steel interface are of significance to their final destinations. All phenomena occur within the metallurgical vessels in meter scale. Thus, ten orders exist in the process from the generation to the final destinations of inclusions in steel, as schematically shown in Figure 1. In the solid steel, inclusions still vary with the temperature and rolling process, which is a potential research focus now and in the future. In the final steel product, inclusions are observed with the five features of three-dimensional (3-D) morphology, composition, size distribution, number density, and spatial distribution.
There are extensive studies on all aspects of nonmetallic inclusions in steel, as shown in Table I, including theoretical studies on the nucleation, collision, and growth of inclusions, interfacial phenomena, thermodynamics for the formation and transformation of inclusions, kinetics in the size and composition of inclusions, fluid flow and inclusion removal in metallurgical vessels, prediction of inclusions in CC products, transformation of inclusions in solid steel, deformation of inclusions in steel during rolling, calcium treatment of the steel, industrial practice of inclusion control, and dependency of steel properties on inclusions.

\section{KINETIC MODELING FOR THE NUCLEATION AND SIZE GROWTH OF INCLUSIONS IN STEEL}

Detailed models and simulation results, including nucleation, collision, and growth of inclusions, ${ }^{[40-70]}$ coupling with the 3-D fluid flow simulation of the molten steel in ladles, the Ruhrstahl-Heraeus (RH) degasser, CC tundish, and CC molds and strands, ${ }^{[52,126-139]}$ were well discussed in former publications.

\section{A. Nucleation and Initial Growth of Inclusion in Molten Steel during Deoxidation}

The nucleation and growth mechanism of an inclusion in the early stage of deoxidation has a great influence on the final features of the inclusion. Using the classical nucleation theory, Turpin and Elliott analyzed the deoxidation and homogeneous nucleation of inclusions in a molten steel and achieved Al-O curves to determine the critical aluminum content for nucleation. ${ }^{[41]}$ The effect of interfacial tension on the nucleation of $\mathrm{Al}_{2} \mathrm{O}_{3}$, $\mathrm{FeO} \cdot \mathrm{Al}_{2} \mathrm{O}_{3}$, and $\mathrm{FeO}$ was detailed, as shown in Figure 3. ${ }^{[41]}$

Wasai and Mukai calculated the Gibbs free energy change as a function of nuclei radius for the nucleation of alumina in liquid iron and found that nucleation occurred rapidly when the initial oxygen content was 
higher than the critical point of nucleation, while the growth of nuclei stopped just after the Gibbs free energy reached its minimum. ${ }^{[44]}$ The formation of unstable alumina in Al-deoxidized steel had been investigated on the basis of Ostwald ripening and two homogeneous nucleation theories. ${ }^{[206]}$ Figure 4 shows the variation of Gibbs free energy with types of alumina. ${ }^{[44]}$ The result indicates that the maximum value associated with liquid alumina is the smallest for the case of $[\mathrm{O}]=0.022$ mass pct. Thus, the authors proposed a formation mechanism of the networklike or coral alumina inclusions by taking into consideration the liquid alumina formation.

Zhang and Pluschkell numerically solved the nucleation and growth of inclusions during deoxidation considering diffusion, Ostwald ripening, and collision. ${ }^{[53]}$ Recently, the multistep nucleation mechanism was also proposed to model the formation of alumina inclusions during steel deoxidation. ${ }^{[49-51]}$ As shown in Figure $5,^{[51]}$

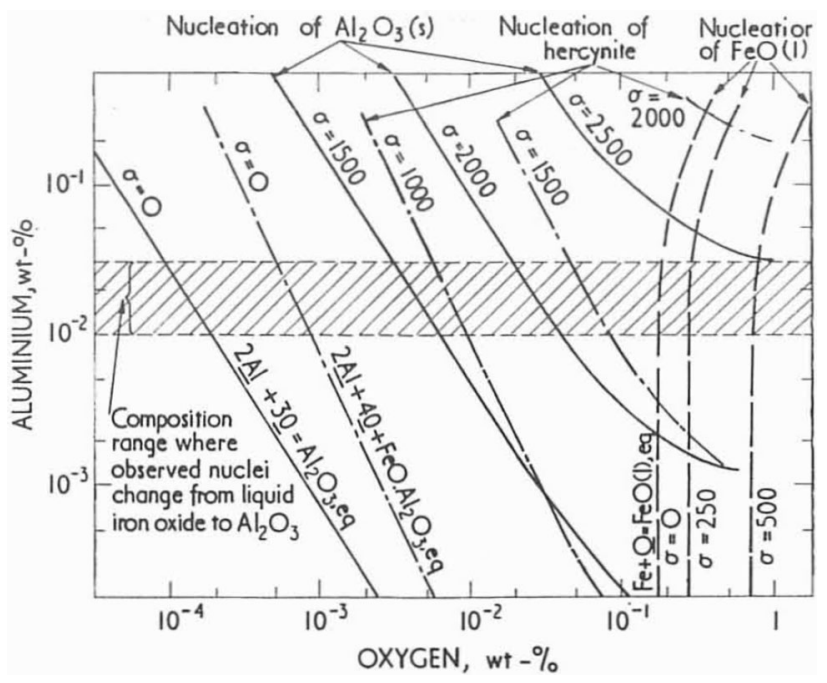

Fig. 3-Effects of interfacial tension and melt composition on nucleation of oxides in the Fe-O-Al system at $1809 \mathrm{~K}\left(1536{ }^{\circ} \mathrm{C}\right)$ (interfacial tension $\sigma$ in ergs $\mathrm{cm}^{-2}$ ). Reprinted from Ref. [41].

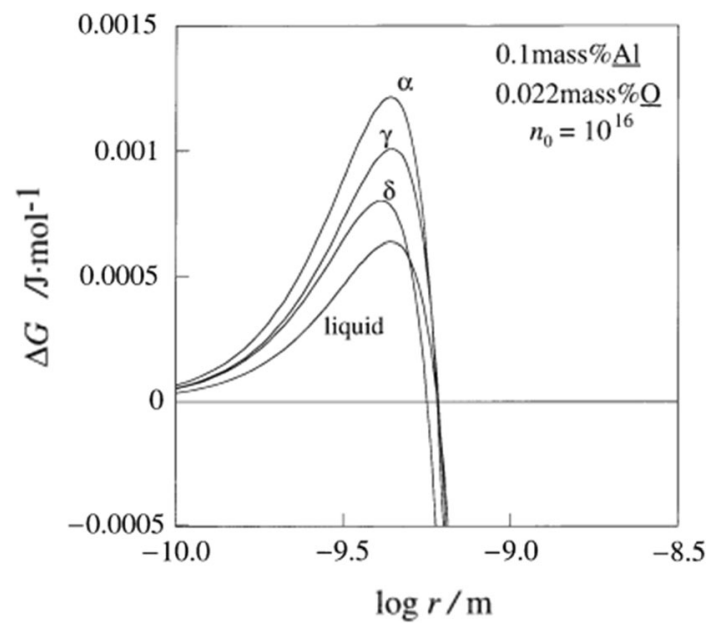

Fig. 4-Dependency of Gibbs free energy on types of alumina. Reprinted from Ref. [44]. the first step is the formation of a sufficient size cluster of molecules and the second step is the reorganization of such a cluster into an ordered structure, and the assembly into $\mathrm{MgO} \cdot \mathrm{Al}_{2} \mathrm{O}_{3}$ structure was attributed to the organization of clusters into ordered lattice structures.

Studies by Nakaoka et al., ${ }^{[207]}$ Zhang and Pluschkell, ${ }^{[53]}$ Ling et al., ${ }^{[208]}$ Zhang and Lee, ${ }^{[47]}$ and Jin et al. ${ }^{[209]}$ developed models to numerically simulate the nucleation and growth of inclusions in steel considering the diffusion of oxygen and deoxidizer elements, Ostwald ripening, Brownian collision, Stokes collision and turbulent collision, and solving size-grouped population balance equations.

The classical nucleation theory gives the critical radius of nucleus, $r_{C}$, as given in Eq. [1]:

$$
r_{\mathrm{C}}=\frac{2 \sigma V_{m}}{R T \ln \Pi}(m)
$$

where $\Pi$ is the actual dimensionless oversaturation in the steel at temperature $T$ (Kelvin), $\sigma$ is the interfacial tension between alumina and liquid steel $\left(\mathrm{N} \mathrm{m}^{-1}\right)$, and $R$ is the gas constant $\left(=8.314 \mathrm{~J} \mathrm{~K}^{-1} \mathrm{~mol}^{-1}\right)$. When the deoxidation is performed by aluminum, $\Pi$ is the concentration of alumina at time $t$ (seconds) divided by the concentration of alumina at equilibrium. If the radius of the group of the pseudo-molecules is larger than the critical radius, stable particles precipitate and start to grow. The time evolution of the group size $N_{i}$ of inclusions is governed by the following particle number balance equation:

for $2 \leq i<i_{C}$ (before nucleation),

$$
\begin{aligned}
\frac{\mathrm{d} N_{i}}{\mathrm{~d} t}= & -\beta_{D, i} N_{1} N_{i}+\beta_{D, i-1} N_{1} N_{i-1}-\alpha_{i} A_{i} N_{i} \\
& +\alpha_{i+1} A_{i+1} N_{i+1}
\end{aligned}
$$

for $i_{C} \leq i<i_{\max }$ (after formation of stable inclusion particles),

$$
\begin{aligned}
\frac{\mathrm{d} N_{i}}{\mathrm{~d} t}= & -\beta_{D, i} N_{1} N_{i}+\beta_{D, i-1} N_{1} N_{i-1}-\alpha_{i} A_{i} N_{i}+\alpha_{i+1} A_{i+1} N_{i+1} \\
& -\phi N_{i} \sum_{j=1}^{\infty}\left(\beta_{B, i, j}+\beta_{T, i, j}\right) N_{j}+\frac{1}{2} \phi \sum_{j=1}^{i-1}\left(\beta_{B, i, i-j}+\beta_{T, j, i-j}\right) N_{j} N_{i-j}
\end{aligned}
$$

where $N$ is the number density of inclusions per unit volume of steel $\left(\mathrm{m}^{-3}\right)$, subscript $i$ is the sequence number of inclusions corresponding to $i$ molecules in this inclusion, and the number of pseudo-molecules per $\mathrm{m}^{3}$ in solution $N_{1}$ equals their total number $N_{s}$ minus those precipitated in inclusions. $N_{1}, N_{S}$, and therefore $\Pi$ are a function of time; the terms $\beta_{D}, \beta_{B}$, and $\beta_{T}$ are the rate constants for diffusion, Brownian collision, and turbulent collision $\left(\mathrm{m}^{3} \mathrm{~s}^{-1}\right)$; the term $\alpha$ is the number of pseudo-molecules that dissociate per second from the $\mathrm{m}^{2}$ area of a particle; and $\phi$ indicates the collision efficiency.

Figure 6 shows the number of $\mathrm{Al}_{2} \mathrm{O}_{3}$ molecules inside the inclusion of the critical size as a function of dimensionless time $\left(=\beta_{11} N_{1, \mathrm{eq}} t\right.$, where $N_{1 \text {,eq }}$ is the number density of pseudo-molecules at equilibrium per unit volume of molten steel in $\mathrm{m}^{-3}$ ) for the deoxidation of steel with a 300 ppm dissolved oxygen by aluminum, 


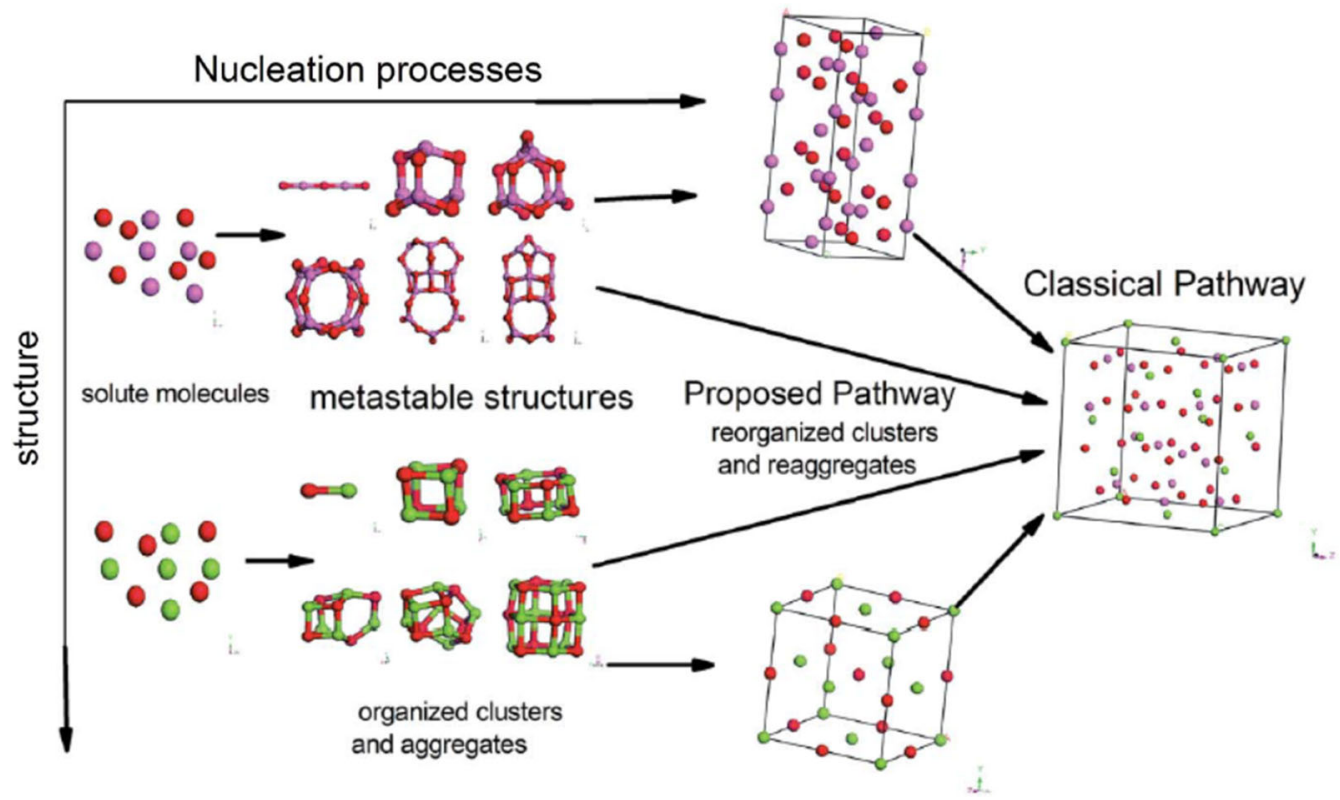

Fig. 5-Multistep nucleation pathway of $\mathrm{MgO} \cdot \mathrm{Al}_{2} \mathrm{O}_{3}$ spinel inclusion in steel. Reprinted with permission from Ref. [51].

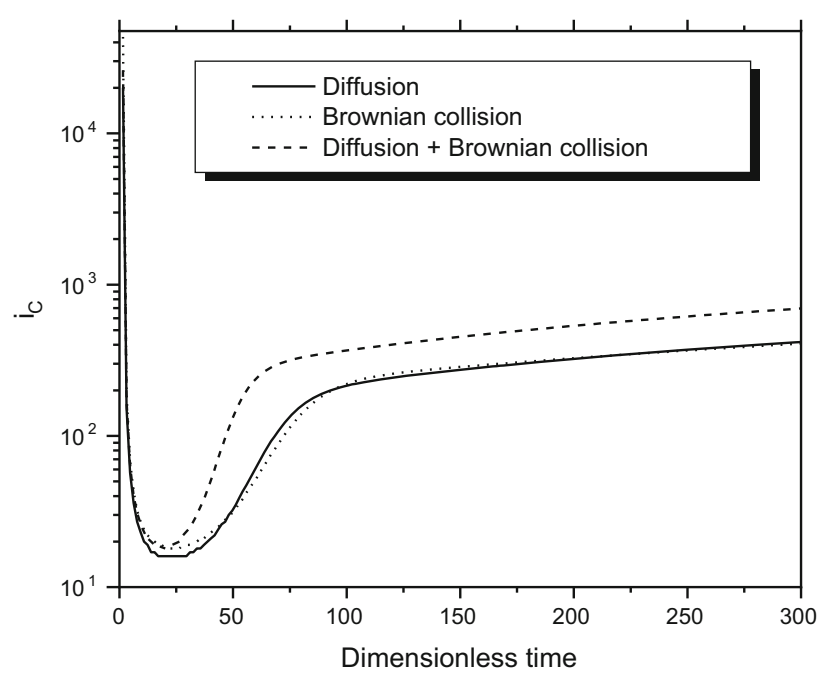

Fig. 6-Number of molecules inside the critical size inclusion, $i_{C}$, vs dimensionless time.

which illustrates the importance of the Brownian collision for the growth of inclusions. The large initial number of $i_{\mathrm{C}}$ implies the difficulty of the nucleation at the beginning after the addition of the deoxidizer; while time goes on, the critical size gets smaller and smaller, and at the best nucleation condition, inclusions with 20 molecules precipitate. Brownian collision enhances the growth of inclusions while it increases the critical size of nucleation, which means the coexistence of more large inclusions and less small inclusions in the molten steel compared to that considering the diffusion of dissolved elements only. Figure 6 shows the very initial growth of inclusions in the molten steel during deoxidation. The dimensionless time is on the order of $2.2 \times 10^{6}$ of real

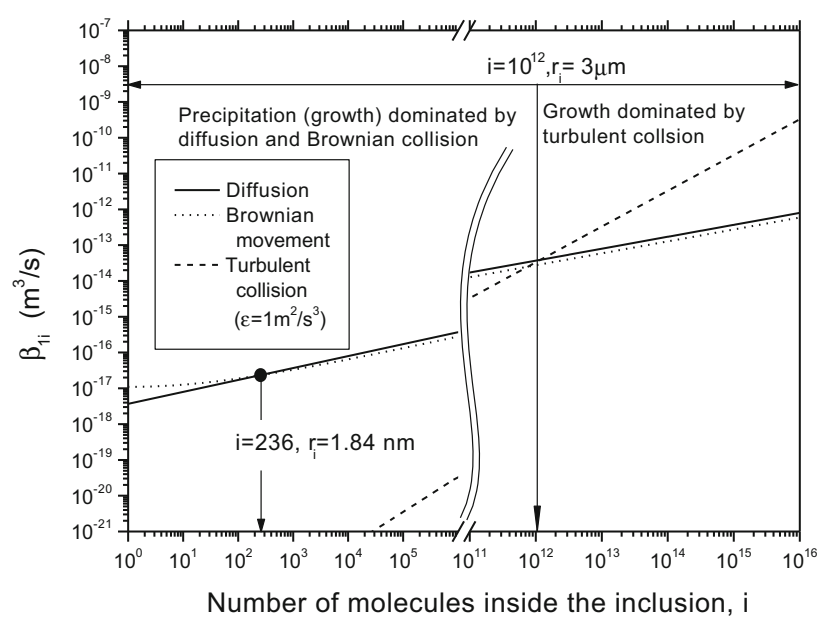

Fig. 7-Rate constant of different growth mechanisms.

time, which means that the nucleation starts within $\mu$ s and, when the time reaches $1 \mathrm{~ms}$, the largest inclusions contain 10,000 molecules, with a size of $6.4 \mathrm{~nm}$.

In order to find the dominant growth mechanism of inclusions at different size ranges, the rate constants of the diffusion, Brownian collision, and turbulent collision are compared, as illustrated in Figure 7. When inclusions are smaller than $3.6 \mathrm{~nm}$, the growth is co-controlled by diffusion and Brownian collision, with Brownian collision contributing a little more. When inclusions are $3.6 \mathrm{~nm}$ to $6 \mu \mathrm{m}$, diffusion contributes slightly more than Brownian collision. For $>6 \mu \mathrm{m}$ inclusions, the growth is dominated by turbulent collision, which depends mainly on the macrofluid flow pattern. 


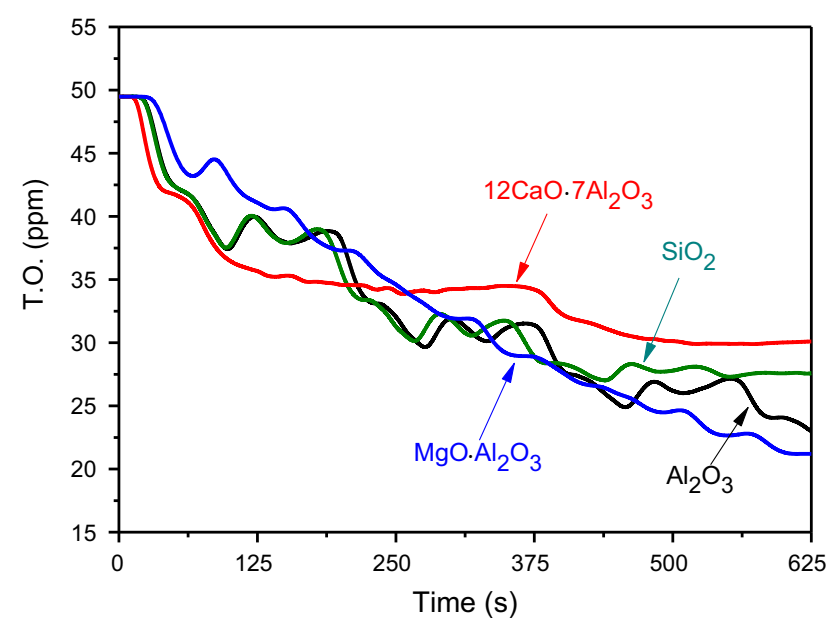

Fig. 8-Concentration of four types of inclusions at the outlet of a CC tundish. Reprinted from Ref. [215].

\section{B. Collision Growth, Motion, and Removal of Inclusion in Molten Steel in CC Tundish}

As early as the 1980s, Shirabe and Szekely, ${ }^{[126]}$ Illegbusi and Szekely, ${ }^{[210]} \mathrm{He}$ and Sahai, ${ }^{[136]}$ and Sinha and Sahai ${ }^{[211]}$ developed models to study the fluid flow and inclusion collision in CC tundish by solving the population balance equation of inclusions. Tozawa et al., ${ }^{[212]}$ Miki and Thomas, ${ }^{[213]}$ Miki et al., ${ }^{[214]}$ Zhang et al., ${ }^{[52]}$ and Ling et al. ${ }^{[215]}$ continued similar work for the RH vacuum degassing process and $\mathrm{CC}$ tundish and included more phenomena such as Brownian collision and the fractal dimension of inclusions. However, the growth of inclusions was calculated by assuming an average stirring intensity in the molten steel and solving a separate concentration equation, and the spatial distribution of inclusions in the molten steel was ignored.

The nucleation phenomena discussed previously is for the initial growth of inclusions to a size of several nanometers. The diameter of an inclusion containing $10^{15}$ molecules reached $60 \mu \mathrm{m}$. The computational ability of the current software and hardware hardly allows the direct calculation of the diffusion of $10^{15}$ molecules. In order to achieve a calculation over a full size range of inclusions, a size grouping model was developed, which was detailed elsewhere. ${ }^{[53,208]}$ As an example, the 3-D fluid flow and the collision, motion, and removal of inclusions in a CC tundish were performed and are discussed subsequently.

By using the size grouping model, Ling et al. ${ }^{[215]}$ coupled the 3-D fluid flow and the collision of inclusions in a $\mathrm{CC}$ tundish, predicted the spatial distribution of inclusions in the molten steel of the entire tundish, and discussed the effect of the composition on the removal of inclusions. As shown in Figure $8,{ }^{[215]}$ inclusions with small contact angles, such as $12 \mathrm{CaO} \cdot 7 \mathrm{Al}_{2} \mathrm{O}_{3}(\theta=54$ to $65 \mathrm{deg}$ at $\left.1873 \mathrm{~K}\left[1600{ }^{\circ} \mathrm{C}\right]\right)$, were more difficult to remove than those with large contact angles, such as $\mathrm{Al}_{2} \mathrm{O}_{3} \quad\left(\theta=140\right.$ deg at $\left.1873 \mathrm{~K} \quad\left[1600^{\circ} \mathrm{C}\right]\right)$ and $\mathrm{MgO} \cdot \mathrm{Al}_{2} \mathrm{O}_{3}\left(\theta=134 \mathrm{deg}\right.$ at $\left.1873 \mathrm{~K}\left[1600{ }^{\circ} \mathrm{C}\right]\right),{ }^{216-220]}$ that were dominated by the interfacial force balance at the steel/slag interface.
The number densities of 1.4- and 72- $\mu \mathrm{m}$ inclusions on the center plane of the tundish are shown in Figure 9. ${ }^{[215]}$ One-micrometer inclusions, the smallest ones in the current calculation, collide with each other and grow into larger ones so that the number density of $1.4-\mu \mathrm{m}$ inclusions is largest at the inlet due to the incoming flow bringing new $1.4-\mu \mathrm{m}$ inclusions, while the largest size $72-\mu \mathrm{m}$ inclusions have an opposite distribution.

\section{Motion, Removal, and Entrapment of Inclusions in CC Strand}

Extensive studies were performed to investigate the 3-D fluid flow and heat transfer related phenomena in steel CC molds and strands using water modeling and mathematical modeling and applying different turbulent models and multiphase models. ${ }^{134,135,140-142,221-265]}$ However, the predictions for the spatial distribution of the number, size, and composition of inclusions on the cross section of CC products are still few. ${ }^{[74,93,94,140-144]}$

After entering the $\mathrm{CC}$ mold, most inclusions are carried deeply into the strand by the down flow and eventually entrapped by the solidified shell. Many mathematical studies on the transport and entrapment of inclusions in $\mathrm{CC}$ strand with the Eulerian-Eulerian method (Figure 10(a)) ${ }^{[266]}$ or Eulerian-Lagrangian method (Figures 10(b) and (c) ) ${ }^{[140,142]}$ were performed. The distribution of inclusions in the steel depended on the interaction between the inclusion and the solidification front during the solidification process. The concept of critical velocity was first proposed to study the entrapment of inclusions at the solidification front. Inclusions were assumed to be engulfed by the solidification front when the speed of the solidification front was greater than the critical velocity, and conversely, inclusions were pushed by the solidification front when the speed of the solidification front was below the critical velocity. ${ }^{[30,31,101,104,111,142,147,267-280]}$

The critical velocity is difficult to accurately calculate so that a suitable criterion for the entrapment of inclusions to the solidified shell is needed. As shown in Figure 11(a), the mushy zone was divided into three zones according to the liquid fraction. ${ }^{[143,281]}$ Inclusions moved into the $q_{2}$ zone because dendrites hardly had an effect on the fluid flow when the liquid volume fraction was greater than 0.6 . Inclusions were captured at the $q_{1}$ zone due to the decrease of the liquid fraction. A simple criterion that inclusions were entrapped at the solidification front with $\mathrm{a}<0.6$ liquid fraction has been widely used. ${ }^{[142,143]}$ This simple criterion was more accurate when inclusions were smaller than primary dendrite arm spacing, while it overpredicted the entrapped fraction of large inclusions. ${ }^{[265]}$

A developed capture criterion was proposed for both small inclusions and large ones, ${ }^{[140,141,265]}$ which included the effect of the primary dendrite arm spacing, local force balance, and local crossflow velocity, as shown in Figure 11(b). Although being encouraging, there is still a certain error between the predicted and the measured spatial distribution of inclusions in $\mathrm{CC}$ products due to the complexity of the interaction 
between the inclusion and the solidification front. Moreover, capture criteria mentioned previously can hardly explain the influence of superheat and sulfur content on the entrapment of inclusions. ${ }^{[22]}$ For subsequent research, it is necessary to predict the inclusion distribution on the entire cross section of the slab and also include the influence of the instantaneous flow field, thermal transfer, solidification structure, solute transport, primary dendrite arm spacing, inclusion size, and forces acting on the inclusion.

The motion of inclusions in CC strand is mainly controlled by the flow of the molten steel due to the micron scale of inclusions. A 3-D fluid flow and the instantaneous distribution of the molten steel, slag phase, air phase, and argon bubble inside a $1300 \times 230 \mathrm{~mm}$ vertical-bending CC strand are shown in Figure 12. ${ }^{[142]}$ The large eddy simulation turbulent model coupled with the volume of fluid multiphase model and Lagrangian discrete phase model was employed to predict the transient multiphase flow and distribution of argon bubbles. The interaction between the molten steel and the argon bubble was included using the user-defined function. The argon gas bubble rose up and passed through the slag layer due to the buoyancy of the steel and slag after exiting from the submerged entry nozzle (SEN). As shown in Figure 12, the relatively large velocity near the SEN was induced by the interaction of the molten steel and bubbles, which caused the higher surface level fluctuation. The excessive argon gas flow rate changed the flow pattern in the strand from a double roll flow to a complex flow and single roll flow due to the lifting effect of bubbles. The removal fraction of inclusions was decreased accordingly with the change of the flow pattern.

In order to predict the spatial distribution of inclusions on the entire cross section of the $\mathrm{CC}$ slab, the solidification and melting model were combined. Inclusions were injected at the inlet of the SEN after the flow field reached a steady state and were assumed to be entrapped by the solidification front where the liquid fraction and the fluid flow speed were less than 0.6 and $0.07 \mathrm{~m} \mathrm{~s}^{-1}$, respectively. The size, composition, and spatial distribution of inclusions on the entire cross section of a low-carbon Al-killed steel CC slab were detected using an automatic scanning electron microscopy-energy dispersive spectroscopy (SEM-EDS) scanning system to validate the inclusion entrapment model.

As shown in Figure 13(a), ${ }^{[283]}$ the measured number density of $3-\mu \mathrm{m}$ inclusions on the entire cross section of the $\mathrm{CC}$ slab indicated four accumulation zones of inclusions along the thickness of the CC slab, including the $1 / 4$ thickness and $3 / 4$ thickness from the loose side, and the layer beneath the surface of the CC slab. The formation of accumulation zones near the $1 / 4$ thickness and $3 / 4$ thickness from the loose side was related to the existence of the curved segment and the solidification transition from the columnar to the equiaxed. The other two accumulation zones were determined by the double roll flow pattern in the $\mathrm{CC}$ strand. The prediction results in Figures 13(b) and (c) show that the distribution of small size inclusions was more discrete, while the distribution of large size inclusions had accumulation
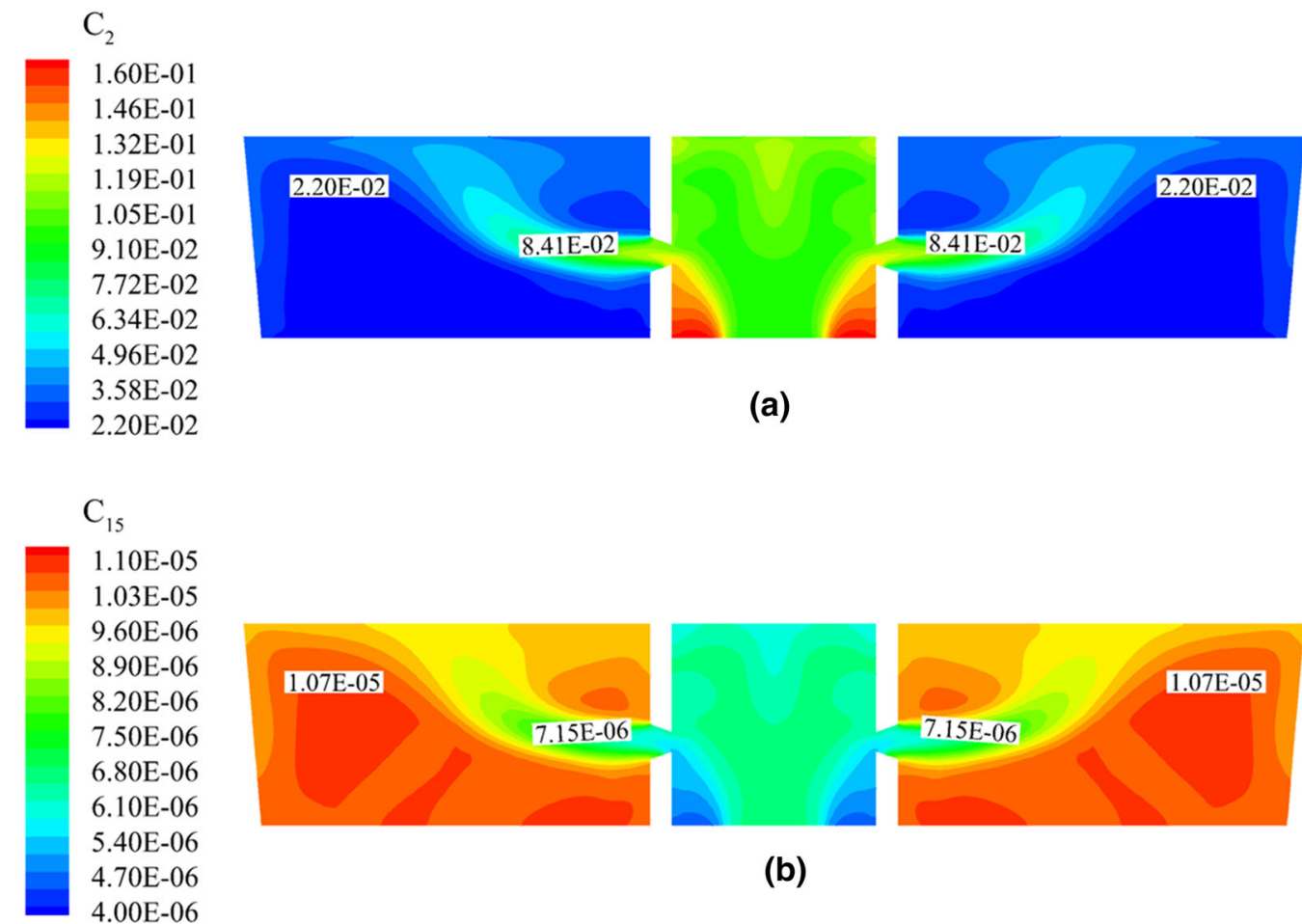

(a)

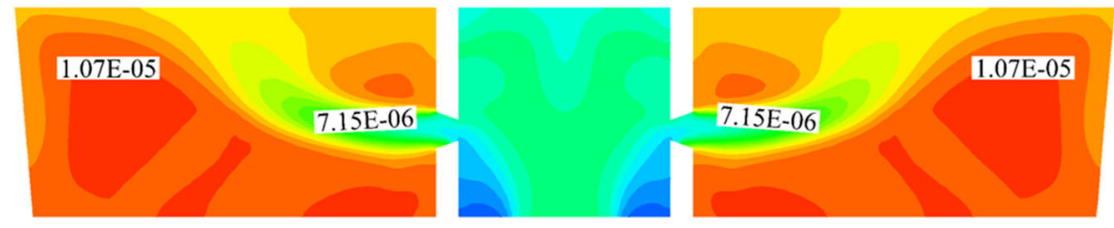

(b)

Fig. 9-Spatial distribution of number of (a) 1.4- $\mu \mathrm{m}$ and $(b) 72-\mu \mathrm{m}$ inclusions per unit volume of steel $\left(\mathrm{m}^{-3}\right)$ on the center plane of the tundish at $625 \mathrm{~s}$ after the steel entering tundish. Reprinted from Ref. [215]. 

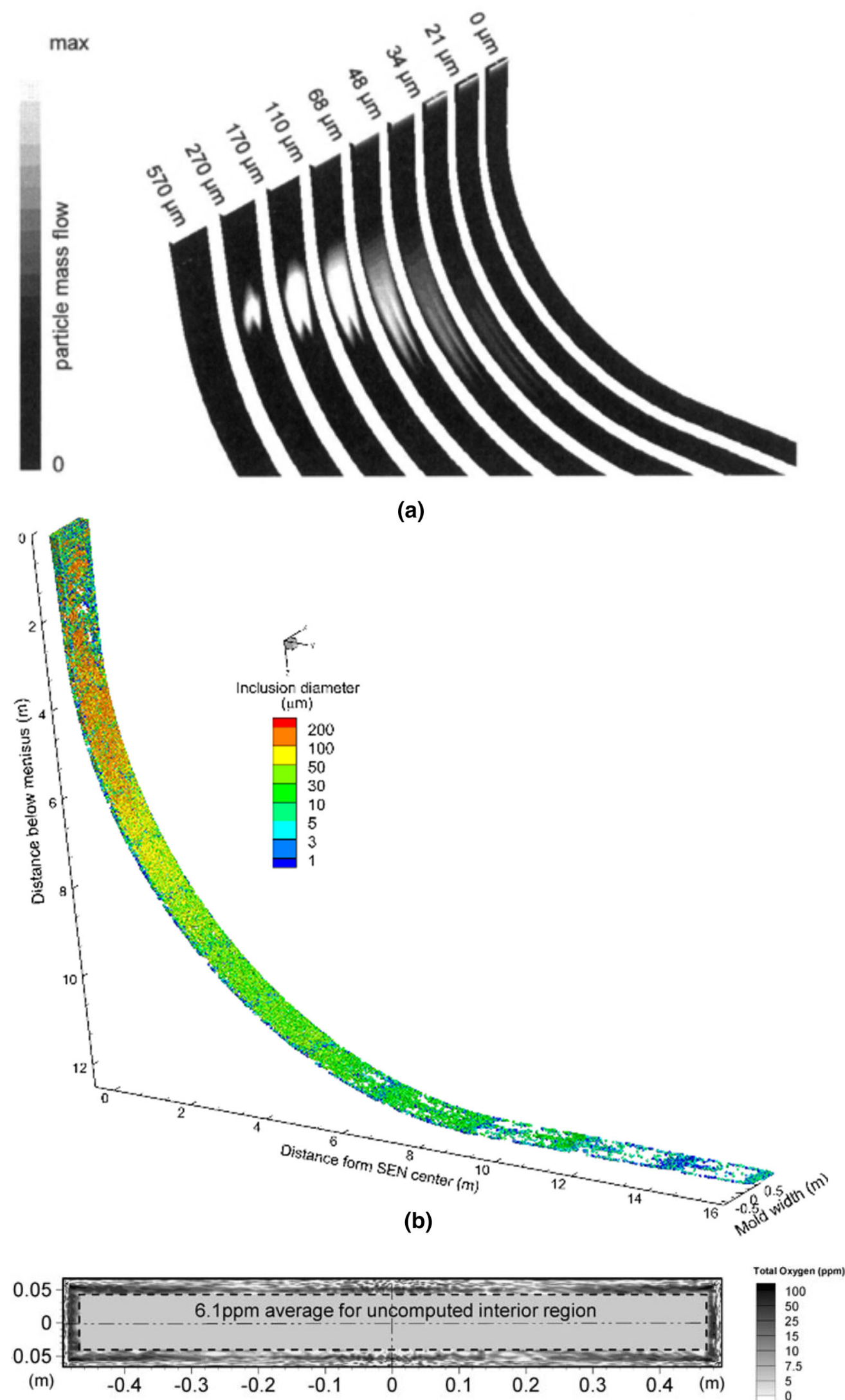

(c) 
4Fig. 10-Distribution of inclusions simulated with the $(a)$ Eulerian-Eulerian method, (b) Eulerian-Lagrangian method for full solidification, and $(c)$ predicted oxygen concentration averaged in the length direction with the Eulerian-Lagrangian method (10 ppm oxygen at nozzle ports). Reprinted with permission from Refs. [140, 142, and 266].

zones. ${ }^{[142]}$ The discrepancy between the prediction and the measurement stemmed from the simplified entrapment model of inclusions. In a future study, an improved inclusion entrapment model will consider the effect of the solidification structure, critical capture velocity, and forces acting on inclusions near the solidification front.

\section{Prediction of Inclusion Composition in CC Products}

In a very recent work, one of the authors established a model to predict the spatial distribution of the composition of inclusions on the cross section of a heavy rail steel CC bloom. The model coupled the heat transfer and solidification of steel during $\mathrm{CC}$, the thermodynamic transformation of inclusions with temperature, and the kinetic diffusion of dissolved elements in the steel, as shown in Figure 14(a). ${ }^{[144]}$ The thermodynamic model calculated the dependency of inclusion composition on temperature (up-right coordinate), while the heat transfer and solidification calculated the variation of temperature at any location of the cross section of the bloom with time and bloom length (up-left and low-left coordinates) so that the dependency of inclusion composition at any location of the cross section of the bloom could be predicted if the kinetic diffusion of the dissolved elements in the solid steel was considered (low-right coordinate).

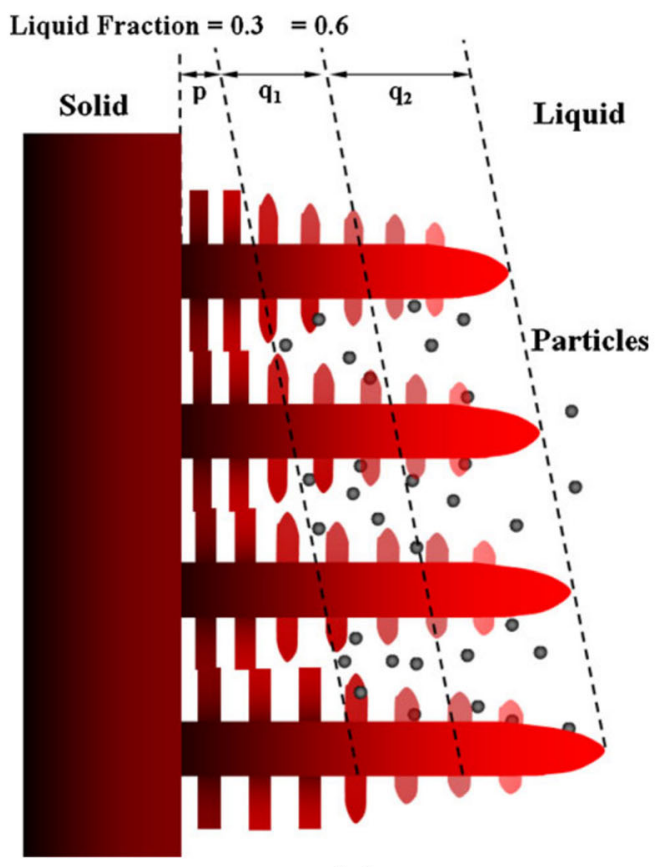

(a)
The predicted composition of inclusions on the cross section of the CC bloom is shown in Figure 14(b) ${ }^{[144]}$ indicating an opposite distribution of $\mathrm{CaO}$ to $\mathrm{CaS}$ due to the reaction between $\mathrm{CaO}$ of inclusions and the dissolved sulfur in the steel and the generation of $\mathrm{CaS}$ in the solid steel during cooling. More specifically, the opposite spatial distribution feature of $\mathrm{CaO}$ to $\mathrm{CaS}$, i.e., less $\mathrm{CaS}$ with the subsurface layer and the center of the bloom, with accumulation of $\mathrm{CaS}$ at $1 / 4$ thickness and $3 / 4$ thickness of the bloom was predicted. The composition of inclusions within the subsurface layer was close to the initial composition of inclusions in $\mathrm{CC}$ tundish due to low transformation caused by the rapid cooling rate. The spatial distribution of the composition of inclusions was generated by the coupling effects of the reaction between the steel and the inclusion, the heat transfer and the cooling rate of the bloom, and the appearance of columnar-to-equiaxed transition in the bloom. The more detailed discussion for the prediction of the spatial distribution of composition of inclusions in $\mathrm{CC}$ bloom can be found elsewhere. ${ }^{[144]}$

\section{DEVELOPMENT OF THERMODYNAMIC MODEL AND DATABASE FOR INCLUSION ENGINEERING}

A fine tuning of inclusion composition is highly important to produce high functional steels because various chemical and mechanical properties of steel products are affected by nonmetallic inclusions. Moreover, serious clogging is frequently encountered in the upper nozzle and submerged entry nozzle due to

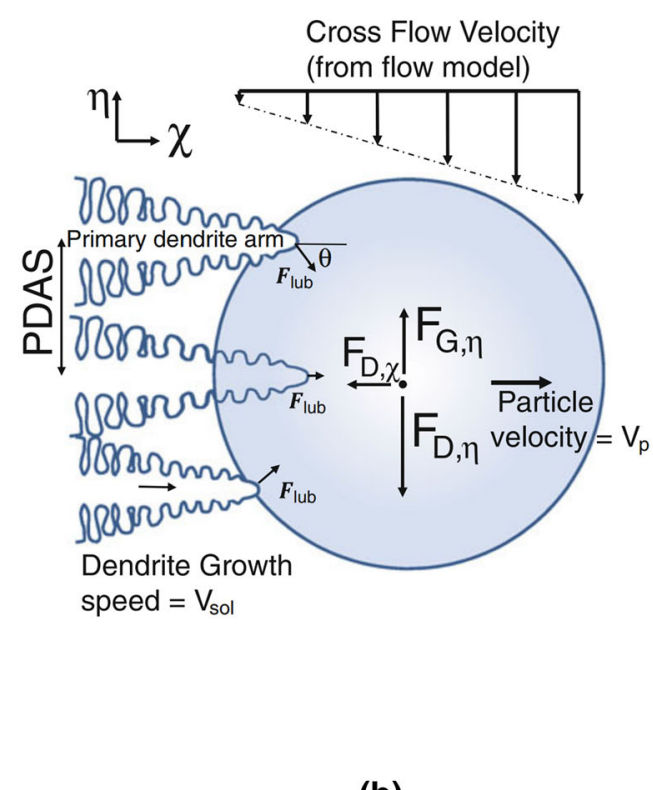

(b)

Fig. 11-Interaction between the inclusion and solidification front: $(a)$ zones of solid-liquid coexisting during solidification and $(b)$ force balance on a particle near a dendritic solidification front. Reprinted from Refs. [140 and 143]. 

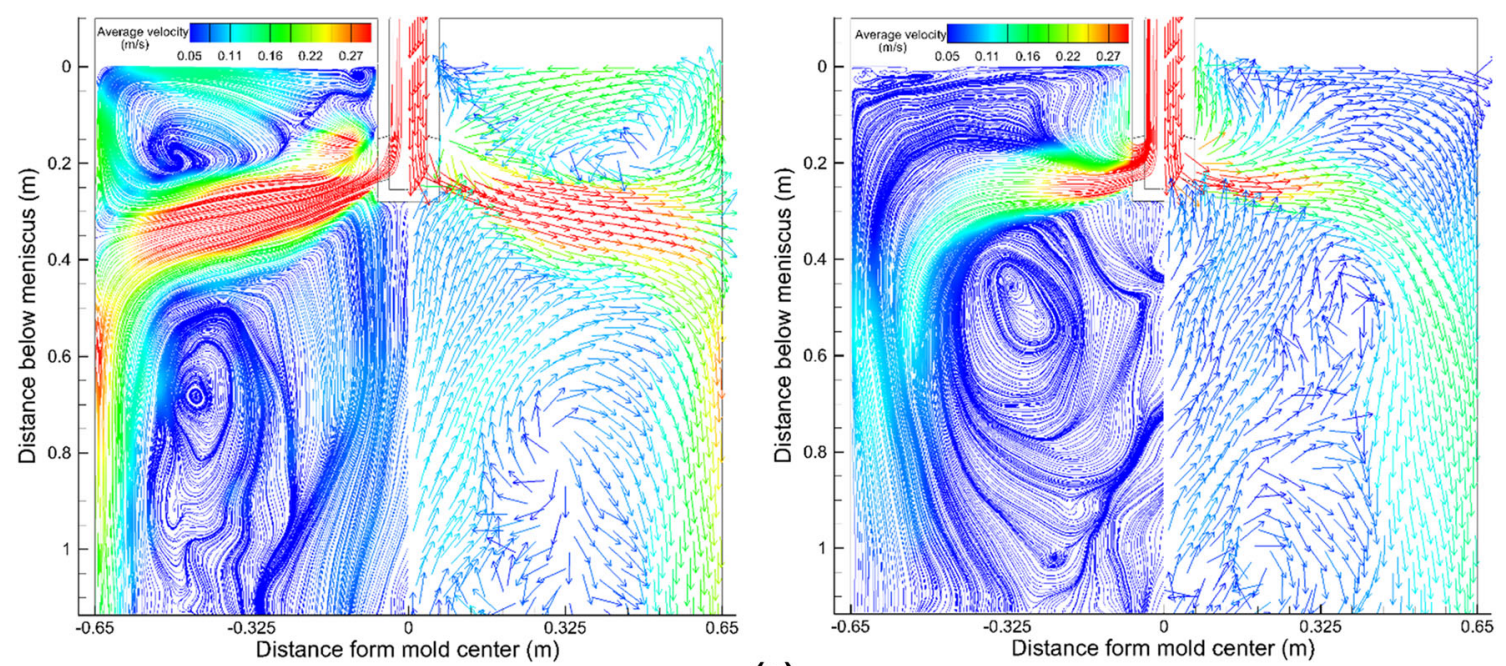

(a)
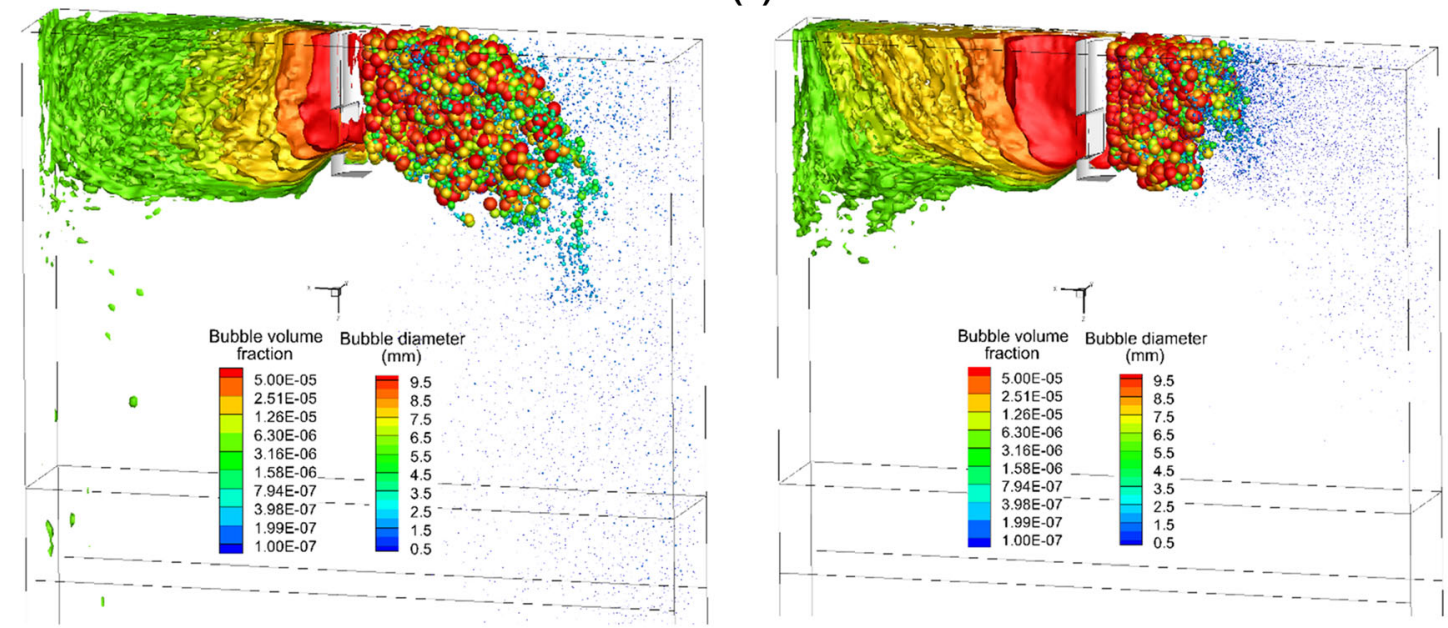

(b)

Fig. 12-Multiphase fluid flow and transient distribution of the molten steel: $(a)$ streamline and velocity vectors; $(b)$ volume fraction, position, and size of bubbles in the CC mold (left: $10 \mathrm{~L} \mathrm{~min}^{-1}$ gas flow rate; right: $61.2 \mathrm{~L} \mathrm{~min}^{-1}$ gas flow rate). Reprinted from Ref. [142].

endogenous and exogeneous inclusions during CC processes. The modeling of fluid dynamics and physical phenomena (agglomeration, floatation, etc.) regarding nucleation, growth, and removal of inclusions are reviewed in Section II. The development of thermodynamic databases as well as trials for combination of thermodynamic multiphase equilibria and mass transport kinetics to predict the inclusion evolution during secondary refining processes will be discussed in this section.

The thermodynamic model to predict the inclusion composition during refining and solidification processes was originally developed by ArcelorMittal in the 1990s. They used their own slag model (i.e., Institut de recherche de la sidérurgie (IRSID) cell model) and developed in-house software, called Chemical Equilibrium Calculation for Steel Industry (CEQCSI), for the calculation of slag-metal reactions. The compositions of oxide and oxysulfide inclusions in (stainless) steels were successfully predicted in molten state as well as in solid state. The crystallization of oxide inclusions during steel solidification was also calculated. ${ }^{[284-286]}$ Later, they developed a generalized central atom (GCA) model to describe more precisely the short-range ordering in metal and slag phases by extension of the cell model and central atom model. ${ }^{[287]}$

Alternatively, one of the thermodynamic databases specifically focusing on inclusion formation behavior during steel refining processes is the FACT database for multicomponent steel and oxide (sulfide, nitride, fluoride) databases developed by the associate model for deoxidation equilibria, the modified quasi-chemical model, in which short-range ordering is taken into account, and compound energy formalism, taking into account the crystal structure of each solution phase. ${ }^{[288-290]}$ The details for developments and applications of FACT databases for deoxidation practices, e.g., $\mathrm{Si} / \mathrm{Mn}, \mathrm{Al} / \mathrm{Ti}, \mathrm{Al} / \mathrm{Ca}$, and $\mathrm{Al} / \mathrm{Mg}$ deoxidations in various steel grades, are available in the literature. ${ }^{[80,291-295]}$ Moreover, the specific review for the 


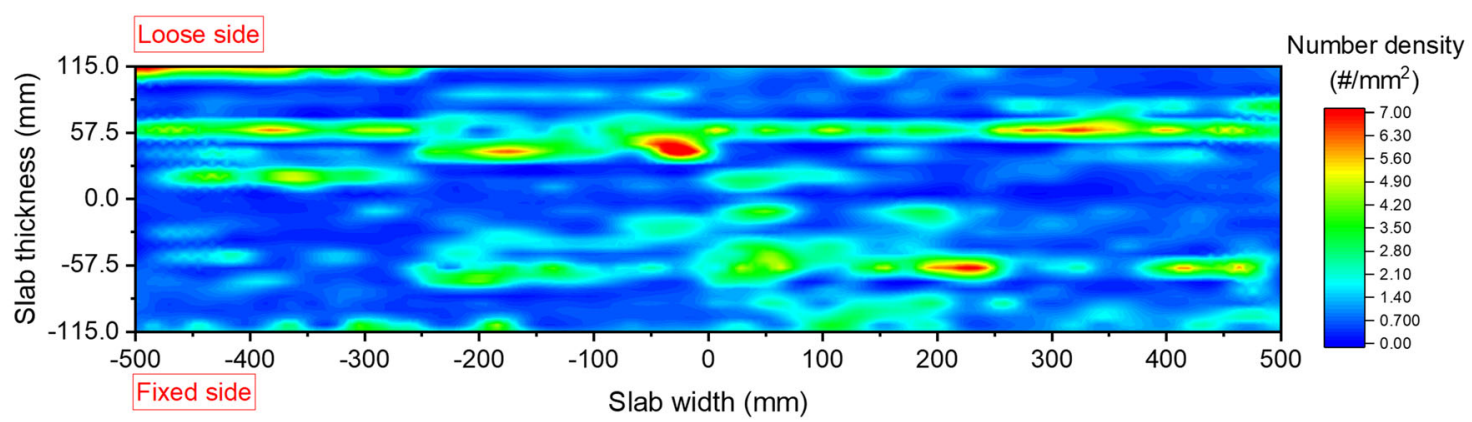

(a)

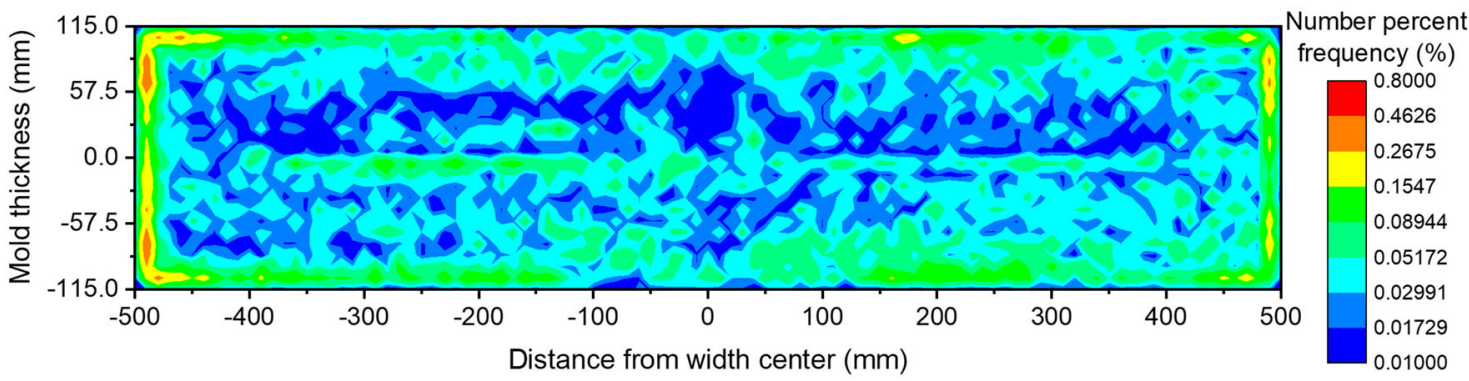

(b)

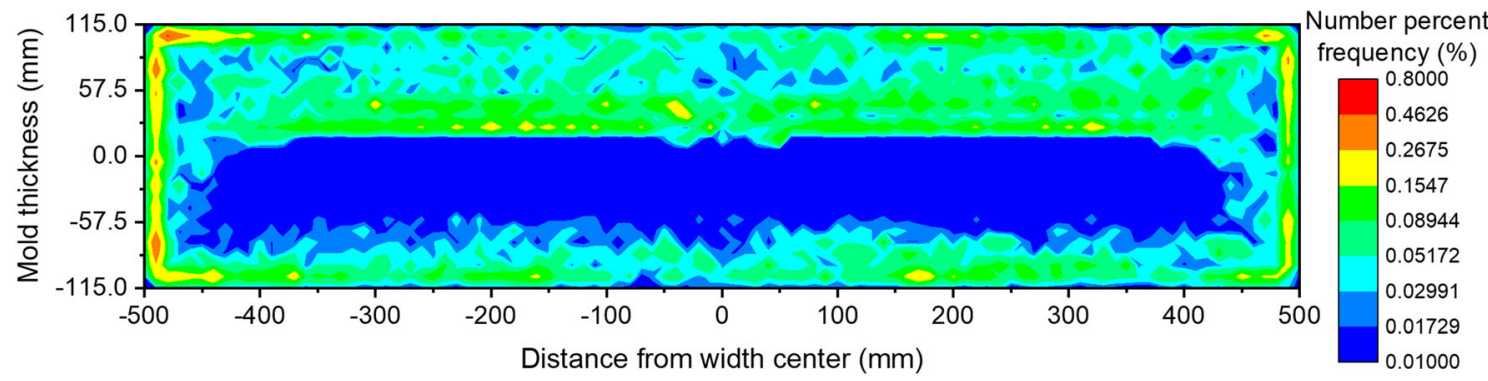

(c)

Fig. 13 - Spatial distribution of inclusions on the entire cross section of the slab: (a) measured number density of 3- $\mu$ m inclusions and prediction results of (b) 3- $\mu \mathrm{m}$ and (c) 30- $\mu \mathrm{m}$ inclusions. Reprinted from Refs. [142 and 283].

characteristics of several thermodynamic databases and packages, i.e., CEQCSI, multicomponent phase equilibria, FACTSAGE, * MTDATA, and Thermo-Calc, is

*FACTSAGE is a trademark of GTT-Technologies, Germany and ThermFact Ltd., Canada.

provided by Jung. ${ }^{[296]}$

\section{KINETIC MODELING FOR THE \\ EVOLUTION OF INCLUSIONS BY REFRACTORY-SLAG-METAL MULTIPHASE REACTIONS}

\section{A. Coupled Reaction Model}

Since 2000, there have been several studies on the kinetic simulation of the secondary ladle refining process, specifically by combining thermodynamic calculations with fluid dynamics of molten steel. One of the representative models to simulate the slag-metal interfacial reactions and the inclusion compositions is the coupled reaction (CR) model. In this model, the mass transfer coefficients of the components in molten steel and slag phases are fitted to satisfy the experimental (or plant) data based on the assumption that the slag-metal reactions are controlled by the mixed mass transfer in slag and metal phases, which was originally proposed by Robertson et al. ${ }^{[297]}$

Okuyama et al. ${ }^{[298]}$ at JFE Steel (formerly Kawasaki Steel) tried to predict the composition changes from $\mathrm{Al}_{2} \mathrm{O}_{3}$ to $\mathrm{MgO} \cdot \mathrm{Al}_{2} \mathrm{O}_{3}$ (MA) spinel in Al-killed ferritic stainless steel by adopting the two film CR model at the slag-metal interface and metal-inclusion interface. They considered two elementary processes, one being a reduction of $\mathrm{MgO}$ in the slag phase by $\mathrm{Al}$ in molten steel and the other being a reaction between $\mathrm{Al}_{2} \mathrm{O}_{3}$ inclusion with $\mathrm{Mg}$ in steel, which was transferred from the slag-metal interface. These two elementary processes are schematically shown in Figure 15. ${ }^{[298]}$ 


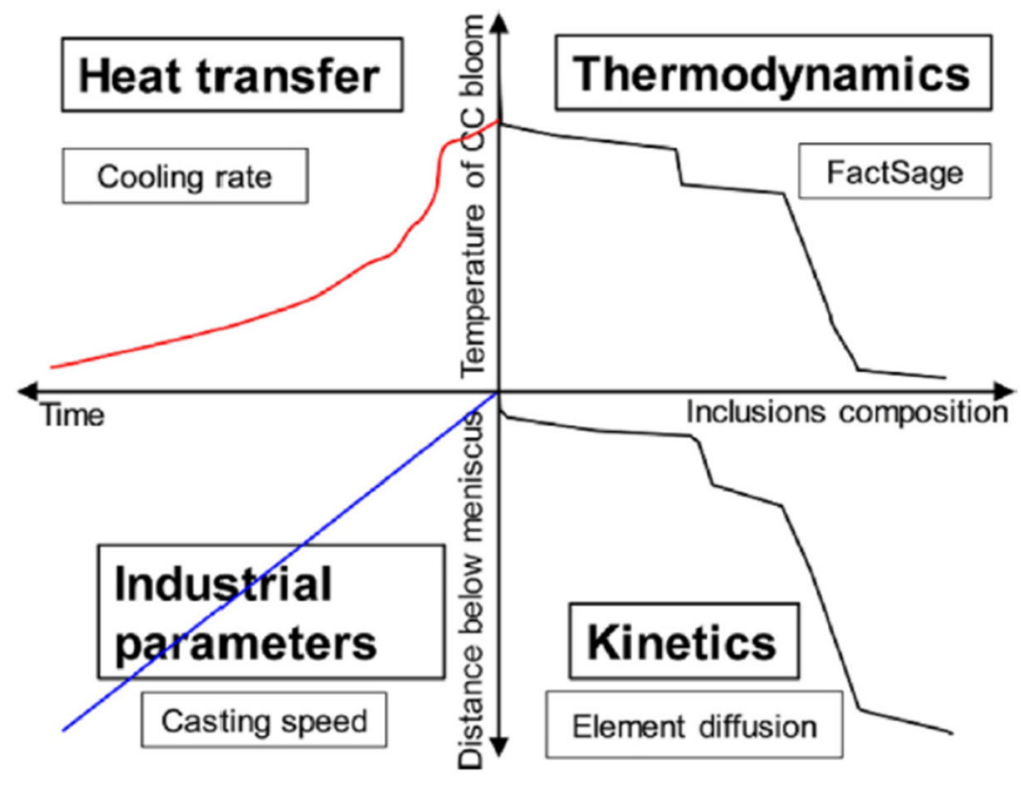

(a)
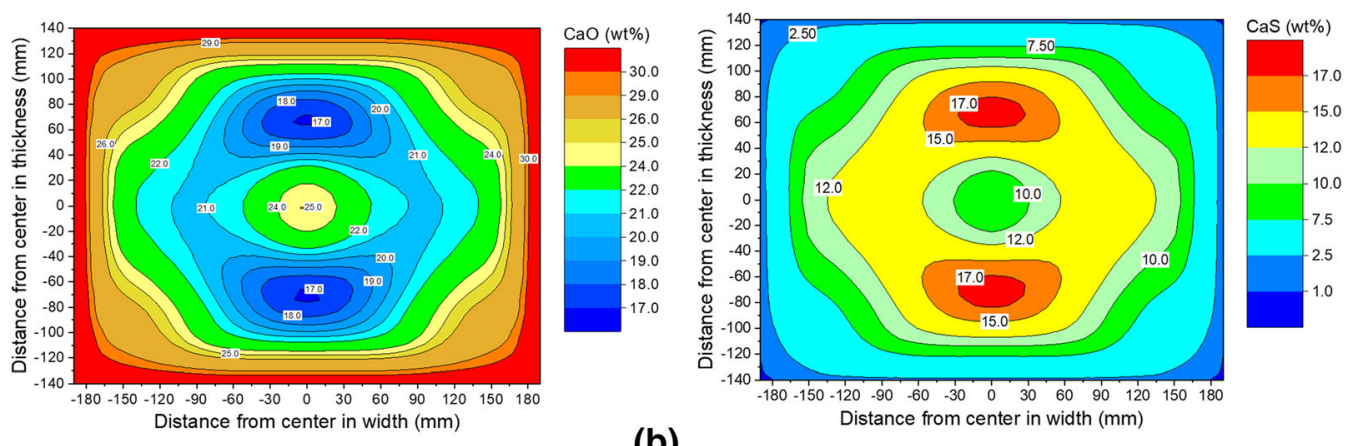

(b)

Fig. 14 (a) Schematic of the integrated model to predict the composition of inclusions in the CC bloom and (b) calculated contour of inclusion composition on the cross section of the CC bloom. Reprinted with permission from Ref. [144].

They assumed the following for the slag-metal reaction kinetics: (1) the slag-metal interfacial reaction has reached equilibrium; (2) the mass transfer coefficient of all elements in the metal side, $k_{m}$, has an identical value; and (3) the mass transfer coefficient for $\mathrm{SiO}_{2}$, $k_{\mathrm{SiO}_{2}}$, is different from the other components in the slag side, $k_{s}$. Therefore, they obtained each value as follows to represent the experimental results: ${ }^{[298]}$

$$
\begin{gathered}
k_{m}=2.0 \times 10^{-4} \quad\left(\mathrm{~m} \mathrm{~s}^{-1}\right) \\
k_{s}=1.0 \times 10^{-5} \quad\left(\mathrm{~m} \mathrm{~s}^{-1}\right) \\
k_{\mathrm{SiO}_{2}}=2.0 \times 10^{-6} \quad\left(\mathrm{~m} \mathrm{~s}^{-1}\right)
\end{gathered}
$$

For the metal-inclusion reaction, they employed the unreacted core model and assumed that (1) the chemical reaction rate at the inclusion-metal interface is sufficiently large, (2) the diffusion of $\mathrm{Mg}$ inside the inclusion is rate controlling, or (3) the diffusion of
$\mathrm{Mg}$ in the steel side is rate controlling. Comparing the calculated results with the experimental observations for the influence of slag composition on inclusion compositions, they concluded that the mass transfer of $\mathrm{Mg}$ through the diffusion boundary layer in the metal side not only at the slag-metal interface but also at the metal-inclusion interface is the rate-controlling step.

Since the late 2000s, the CR model has been actively used by the McMaster University Research Group (MURG). ${ }^{[299,300]}$ Graham and Irons tried to apply this model to a 165-ton ladle furnace (LF) in ArcelorMittal Dofasco by employing CEQCSI software to calculate the slag-metal equilibrium reactions. The metal phase mass transfer coefficient of the elements $\left(k_{\mathrm{m}}\right)$ was obtained as a function of effective stirring power $(\varepsilon)$ in molten steel, as given in Eqs. [6] and [7]. ${ }^{[29,300]}$ The slag phase mass transfer coefficient of oxide components $\left(k_{s}\right)$ was obtained as given in Eq. [8] depending on the sort of oxides. They also employed different $k_{s}$ values for $\mathrm{SiO}_{2}$ compared to other oxide components in slag, as Okuyama et al. likely did as well. 

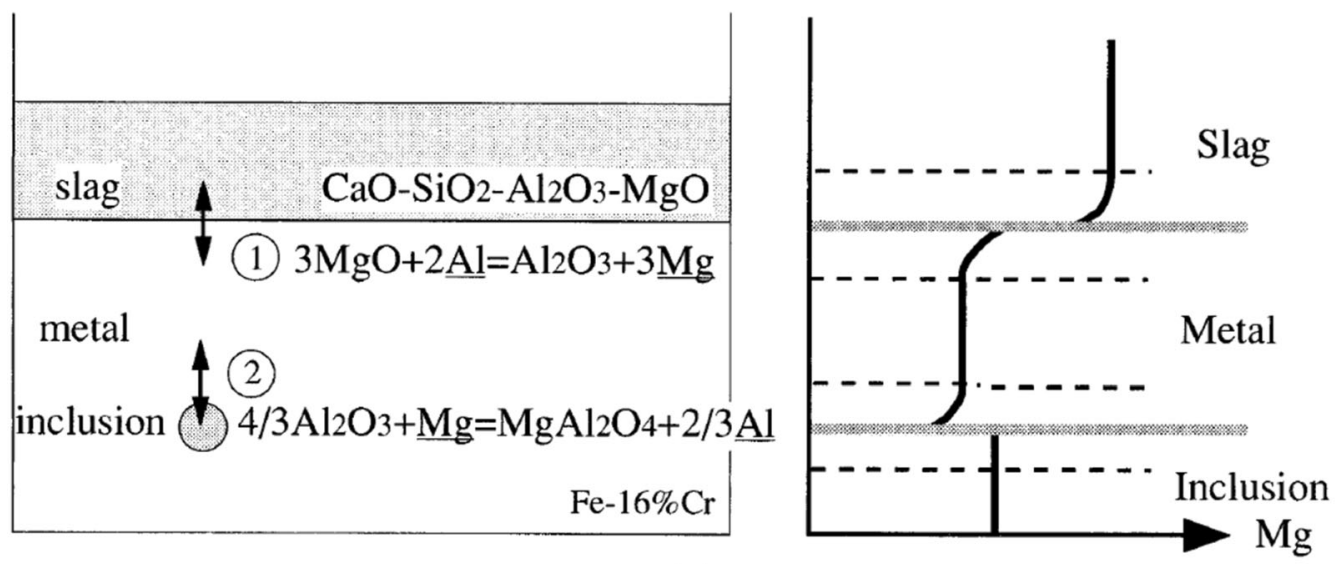

(a)

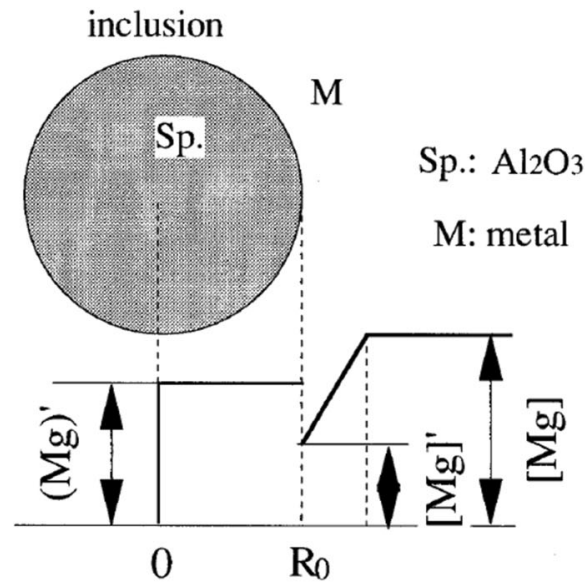

(b)

Fig. 15-Schematic diagram for (a) the reaction among slag, steel, and inclusion, as well as the Mg content in slag, steel, and inclusion; $(b) \mathrm{Mg}$ content distribution in molten steel and inclusion based on the assumption that $\mathrm{Mg}$ diffusion in the boundary layer of molten steel is a rate-controlling step. Reprinted with permission from Ref. [298].

$$
\begin{gathered}
\varepsilon=\frac{\dot{n} \mathrm{R} T}{W_{m}} \ln \left(\frac{P_{t}}{P_{o}}\right) \quad\left(\mathrm{W} \mathrm{t}^{-1}\right) \\
k_{m}=0.006( \pm 0.002) \varepsilon^{1.4( \pm 0.09)} \quad\left(\mathrm{m} \mathrm{s}^{-1}\right) \\
k_{s}=0.05 \text { to } 0.14 k_{m} \quad\left(\mathrm{~m} \mathrm{~s}^{-1}\right) \\
\text { for } \mathrm{FeO}, \mathrm{MnO}, \text { and } \mathrm{Al}_{2} \mathrm{O}_{3}
\end{gathered}
$$

$$
k_{s}=0.01 \text { to } 0.02 k_{m} \quad\left(\mathrm{~m} \mathrm{~s}^{-1}\right) \quad\left(\text { for } \mathrm{SiO}_{2}\right)
$$

where $\dot{n}\left(\mathrm{~mol} \mathrm{~s}^{-1}\right), R\left(\mathrm{~J} \mathrm{~mol}^{-1} \mathrm{~K}^{-1}\right), T$ (Kelvin), $W_{m}$ (ton), $P_{t}$ (atm), and $P_{o}$ (atm) represent the molar gas flow rate, gas constant, temperature, weight of molten steel, total gas pressure at the base of the ladle, and gas pressure at the melt surface, respectively. The relationship between $k_{m}$ and $\varepsilon$ is given in Figure 16. ${ }^{[300]}$ Later, this model was applied to predict the Mg transfer from the slag-metal interface to bulk Al-killed steel, resulting in the transformation of $\mathrm{Al}_{2} \mathrm{O}_{3}$ to $\mathrm{MgAl}_{2} \mathrm{O}_{4}$ (MA) spinel. ${ }^{[301]}$
In the next step, MURG tried to combine this slag-metal kinetic model into the inclusion-steel kinetic model, including $\mathrm{Ca}$ diffusion from $\mathrm{Ca}$ bubbles to $\mathrm{Al}_{2} \mathrm{O}_{3}$ or MA spinel inclusions to predict the modification procedure by Ca treatment in LF ${ }^{[302-304]}$ However, due to the difficulty of measuring the mass transfer coefficient of calcium at the bubble boundary layer $\left(k_{\mathrm{Ca}, \mathrm{L}}\right)$ as well as the bubble interfacial area $\left(A_{B, L}\right)$, these parameters were taken from the work of $\mathrm{Lu}$ et $a .^{[305]}$ by fitting to industrial data. ${ }^{[303]}$ MATLAB** $^{*}$ software was used by

**MATLAB is a trademark of MathWorks, Inc., Natick, MA.

MURG to develop a code for solving the equations.

The CR model was also adopted by the Tohoku University Research Group (TURG). Harada et al. ${ }^{[107,108,109,306]}$ developed an LF model focusing on the prediction of the inclusion composition. The bulk of the idea is quite similar to that of MURG. TURG considered the dissolution of $\mathrm{MgO}$ refractory into the slag phase (i.e., mass transfer coefficient of $\mathrm{MgO}$ ) as well 
as the floatation-entrapment-agglomeration of inclusions. The calculation concept proposed by TURG is shown in Figure 17..$^{107]}$

They linked thermodynamic calculation results, which were obtained using FACTSAGE software, to the developed program coded by Visual $\mathrm{C}++$ through ChemApp. The sulfide capacity of the slag was calculated using Sosinsky-Sommerville's optical basicity model. ${ }^{[307]}$ As MURG similarly tried, the $k_{m}$ was calculated using an empirical equation as a function of $\varepsilon$, which was reported by Kitamura et al. ${ }^{[308]}$

$$
\varepsilon=\underset{\left(\mathrm{W} \mathrm{ton}^{-1}\right)}{\frac{6.18 Q_{g} T}{W_{m}}}\left\{\ln \left(1+\frac{h_{o}}{1.46 \times 10^{-5} P_{a}}\right)+\left(1-\frac{T_{n}}{T}\right)\right\}
$$

$$
k_{m}=1.98+0.5 \log \left\{1,000 \varepsilon\left(\frac{h_{v}^{2}}{d_{v}}\right)\right\}-\frac{125,000}{2.3 \mathrm{R} T}\left(\mathrm{~m} \mathrm{~s}^{-1}\right)
$$

$$
\begin{gathered}
k_{s}=0.1 k_{m} \quad\left(\mathrm{~m} \mathrm{~s}^{-1}\right) \\
k_{\mathrm{MO}}=k_{s} \sqrt{\frac{D_{\mathrm{MO}}}{D_{\mathrm{CaO}}}}\left(\mathrm{m} \mathrm{s}^{-1}\right)
\end{gathered}
$$

where $Q_{g}$ is the $\mathrm{Ar}$ gas flow rate $\left(\mathrm{Nm}^{3} \min ^{-1}\right) ; h_{o}$ and $h_{v}$ are the injection and bath depth (m), respectively; $d_{v}$ is the diameter of the ladle $(\mathrm{m}) ; P_{a}$ is the atmospheric pressure (atm); $T_{n}$ is the gas temperature (Kelvin); $k_{\mathrm{MO}}$ is the slag phase mass transfer coefficient of oxide MO in the diffusion boundary (film) layer $\left(\mathrm{m} \mathrm{s}^{-1}\right)$; and $D_{i}$ is the diffusion coefficient of oxide component $i$ in the slag phase $\left(\mathrm{m}^{2} \mathrm{~s}^{-1}\right)$. It is interesting that TURG employed the relative mass transfer coefficient of slag components with a reference to $\mathrm{CaO}$ considering the diffusivity of each oxide.

However, they employed a different equation to obtain $k_{m}$ for consideration of inclusion particles originating from the slag by physical entrapment. Even more, the $k_{m}$ was assumed to be 1/50 of the estimated value in their actual calculation because the composition change of each element in the inclusion originating from the slag is too fast and unstable. For the parameters on floatation, entrapment, and agglomeration of inclusions, they used the values as follows: (1) flotation rate $=0.1$ pct s${ }^{-1}$, (2) entrapment rate $=10^{-6} \mathrm{~s}^{-1}$ (for $10-\mu \mathrm{m}$ particles), and (3) agglomeration rate $=1$ pct s${ }^{-1}$. However, these parameters should be arbitrarily varied to fit the experimental data at different experimental conditions. ${ }^{[109,306]}$

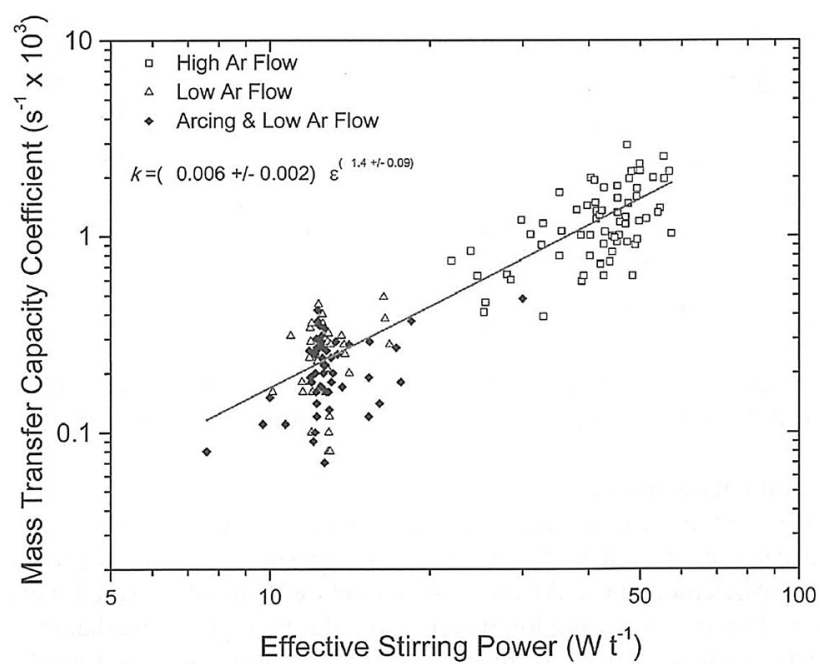

Fig. 16-Relationship between the mass transfer coefficient and effective stirring power. Reprinted with permission from Ref. [300].

Huang et al. ${ }^{[98]}$ adopted the CR model to simulate the formation behavior of spinel inclusion in Al-killed steel due to a dissolution of $\mathrm{MgO}$ refractory. The mass transfer coefficient of the metal phase was determined by fitting the experimental data reported by Harada et al. ${ }^{[309]}$ as a function of the stirring energy dissipation rate as given in Eq. [12]. The calculation was coded by Visual $\mathrm{C}++$.

$$
k_{m}=\left(5.6-4.7 e^{-96.6 \dot{\varepsilon}}\right) \times 10^{-4}\left(\mathrm{~m} \mathrm{~s}^{-1}\right)
$$

where $\dot{\varepsilon}$ is the stirring energy (dissipation rate) $\left(\mathrm{W}\right.$ ton $^{-1}$ ).

Alternatively, Liu et al.${ }^{[310]}$ deduced the mass transfer coefficient of magnesium in molten steel as given in Eq. [13]. The difference between Eqs. [12] and [13] originated from different experimental conditions; i.e., Harada et al. ${ }^{[309]}$ employed the dynamic finger rotating method (Huang et al. ${ }^{[98]}$ used Harada et al.' ${ }^{[309]}$ experimental data in the simulation), while Liu et al. ${ }^{[310]}$ employed the static finger dipping method.

$$
k_{m}=5 \times 10^{-4} \quad\left(\mathrm{~m} \mathrm{~s}^{-1}\right)
$$

Even though the CR model exhibits a good predictability for a specific operation condition, as shown in previous studies, several nonlinear flux balance equations for each element transferring the slag-metal interface and metal-inclusion interface should be solved using the numerical method. Thus, the kinetic parameters, such as mass transfer coefficients of components in metal and slag phases $\left(k_{m}\right.$ and $\left.k_{s}\right)$, should be fitted to reproduce the specific plant or laboratory experimental data. The floatation, entrapment, agglomeration, and removal rate should also be optimized to reproduce the experimental data and in a somewhat arbitrary way according to the operation conditions. 


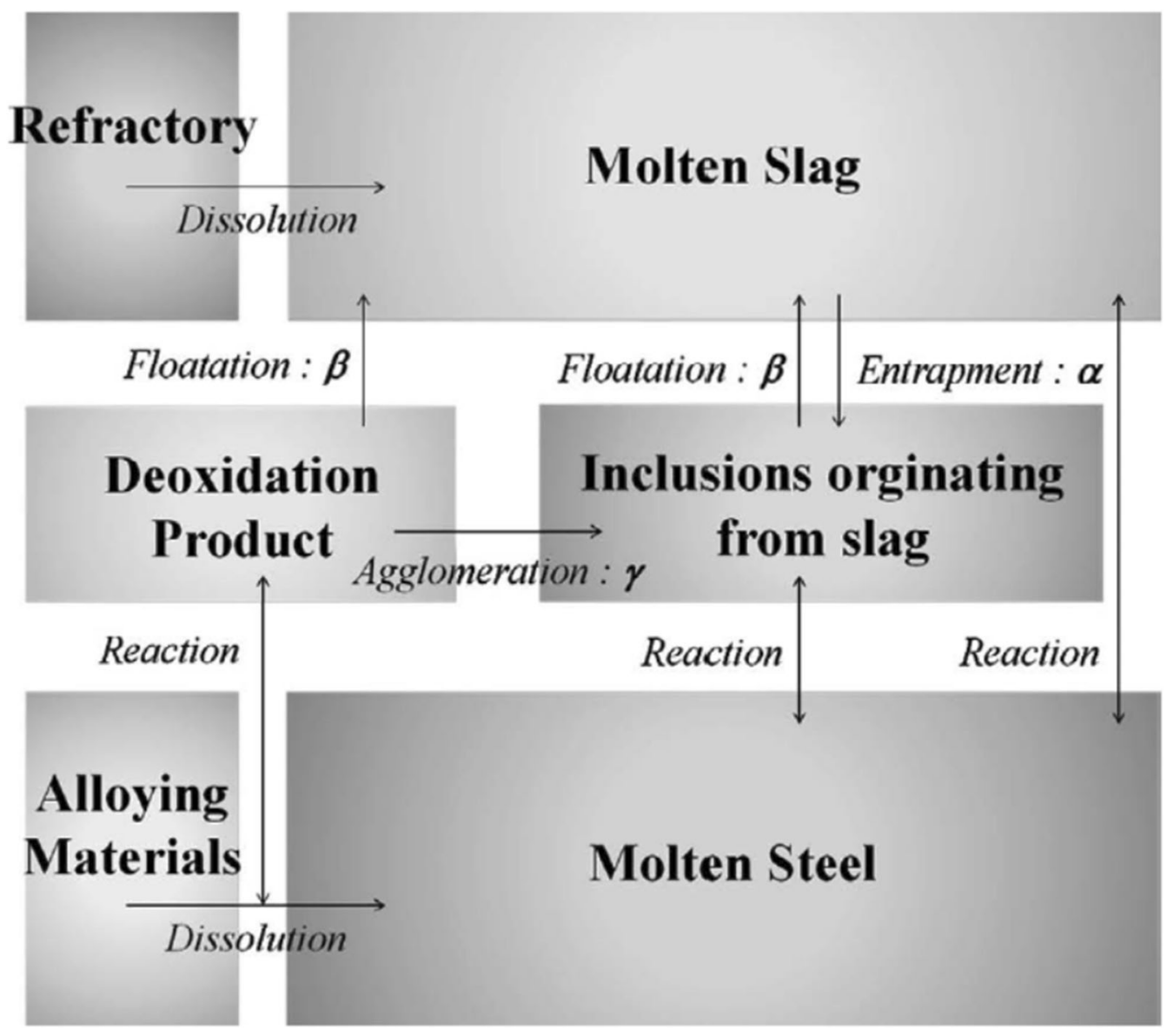

Fig. 17-Calculation concept of TURG. Reprinted with permission from Ref. [107].

\section{B. Reaction Zone Model}

An alternative approach to predict the slag-metal (and gas-metal) reaction kinetics has been proposed by several researchers. This model is based on the assumption of the equilibrium of all species and phases in a specific reaction zone, i.e., not at the reaction interface only but in a reaction volume near the interface. Hence, in the reaction zone model, the determination of the reaction volume is very important, instead of the mass transfer coefficient of each element itself. The original idea was proposed by Asai et al..$^{[311-313]}$ to predict the steel composition and temperature for decarburization in the Linz-Donawitz converter as well as in the argon oxygen decarburization converter. The model was further developed by Ding et al. ${ }^{[314]}$ for application to the vacuum oxygen decarburization (VOD) process for stainless steelmaking. The schematic drawings of the model concept proposed by Hsieh et al. ${ }^{[313]}$ and Ding et al..$^{[314]}$ are shown in Figure 18. Ding et al. ${ }^{[314]}$ employed several parameters in their model, as shown in Eqs. [14] through [16], to represent the industrial (120-ton VOD at ALZ plant) data for several stainless steel grades:

$$
M_{\mathrm{mg}}^{t}=\eta_{1} \cdot W_{M}^{t} \quad(\mathrm{~kg})
$$

$$
\begin{aligned}
& M_{\mathrm{ms}}^{t}=\eta_{2} \cdot W_{M}^{t} \quad(\mathrm{~kg}) \\
& M_{\mathrm{sm}}^{t}=\eta_{3} \cdot W_{S}^{t} \quad(\mathrm{~kg})
\end{aligned}
$$

where $M_{\mathrm{mg}}^{t}, M_{\mathrm{ms}}^{t}$, and $M_{\mathrm{sm}}^{t}$ are the mass of metal in the gas-metal reaction zone, the mass of metal in the slag-metal reaction zone, and the mass of slag in the slag-metal reaction zone at time $t$, respectively. The $W_{M}^{t}$ and $W_{S}^{t}$ are the total metal and slag weight $(\mathrm{kg})$, respectively, at time $t$. The $\eta_{1}, \eta_{2}$, and $\eta_{3}$ are adjustable parameters that relate the fraction of metal taken into the gas-metal reaction zone to the total amount of metal in time interval $\Delta t$, the fraction of metal taken into the slag-metal reaction zone to the total amount of metal in time interval $\Delta t$, and the fraction of slag taken into the slag-metal reaction zone to the total amount of slag in time interval $\Delta t$, respectively. However, the inclusion system was not considered in Hsieh et al. ${ }^{[313]}$ and Ding et al.' ${ }^{[314]}$ models.

The preceding reaction zone model was adopted by Van Ende and Jung's research group (VJRG) and further extended to the more complicated systems such as the RH degassing process, ${ }^{[315]} \mathrm{CC}$ process, ${ }^{[316]}$ and 


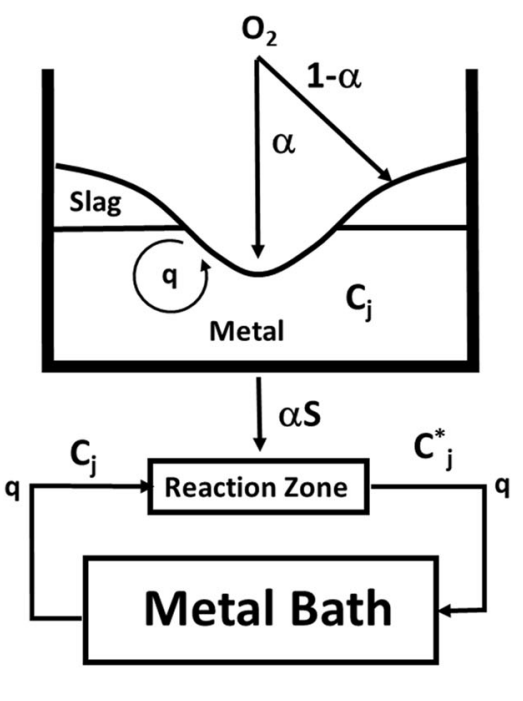

(a)

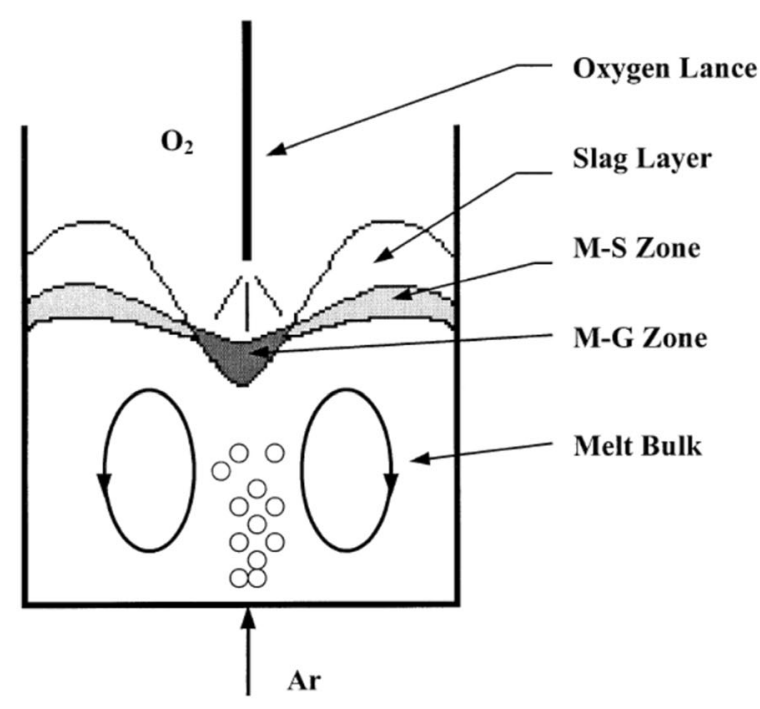

(b)

Fig. 18 - Schematic drawing of the reaction zone model: (a) proposed by Hsieh et al. and (b) proposed by Ding et al. Reprinted with permission from Refs. [313 and 314].

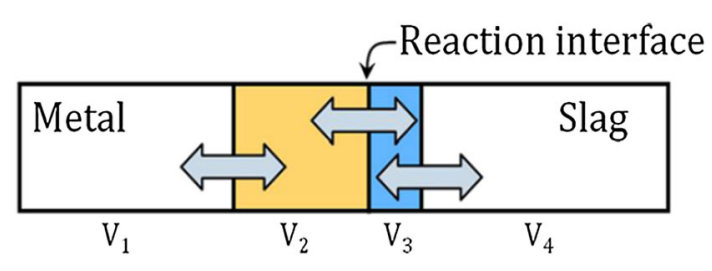

Fig. 19- Concept of the EERZ model for the slag-metal reaction. Reprinted from Ref. [317].

LF refining process. ${ }^{[317]}$ They used the term effective equilibrium reaction zone (EERZ) model. The concept of the EERZ model for the slag-metal reaction is shown in Figure 19, and a schematic diagram of the reaction zones in the RH degasser and LF is represented in Figure 20. ${ }^{[315-317]}$

In the simplified slag-metal reaction (Figure 19), the equilibrium would be first calculated between small reacting volumes in metal (V2) and slag (V3) near the interface, followed by the homogenization reaction in metals (V1 and V2) and slags (V3 and V4), respectively. The equilibrium reactions in the effective reaction zone can be calculated using FACTSAGE software with the embedded "Macro Processing" coding function. More details for the applications of FACTSAGE Macro Processing are given by VJRG. ${ }^{[315-317]}$

The amount of metal and slag participating in the chemical reaction at the interface was simply expressed as follows:

$$
R W_{\text {solution }}=(k \rho A)_{\text {solution }} \Delta t \quad(\mathrm{~kg})
$$

where $R W_{\text {solution, }} k$, and $\rho$ are the reacting amount, overall mass transfer coefficient $\left(\mathrm{m} \mathrm{s}^{-1}\right)$, and density of the given solution $\left(\mathrm{kg} \mathrm{m}^{-3}\right)$, respectively. The term $A$ is the area of reaction interface $\left(\mathrm{m}^{2}\right)$, and $\Delta t$ is the given time-step (s). For example, in the calculation of $R W_{\text {metal }}$ and $R W_{\text {slag }}$, i.e., $k_{m}$ and $k_{s}$ values in reaction zone 4 at the slag-metal interface in Figure 20(b), they employed Eqs. [6] and [7] for $k_{m}$, which was proposed by Graham and Irons. ${ }^{[299]}$ Also, they used Eq. [11a] for $k_{s}$.

The full homogenization mixing in the slag (zone 5) and metal (zone 6) phase was assumed as in Figure 20(b). It was also assumed that nonmetallic inclusions are homogeneously distributed in the entire volume of liquid steel under equilibrium (zone 7). Thus, the average inclusion chemistry can be given in the EERZ model, although the inclusion chemistry is inhomogeneous and several kinds of inclusion can be found even in the same sample at the same position in reality. The constant removal rate of inclusions was assumed depending on the reaction zone volume at each calculation step. For the simulation, the Microsoft $\mathrm{EXCEL}^{\dagger}$ interface was used, and thermodynamic equi-

${ }^{\dagger}$ EXCEL is a trademark of Microsoft Corporation

libria of all reaction zones were calculated adiabatically using FACTSAGE with FToxid and FTmisc database. 


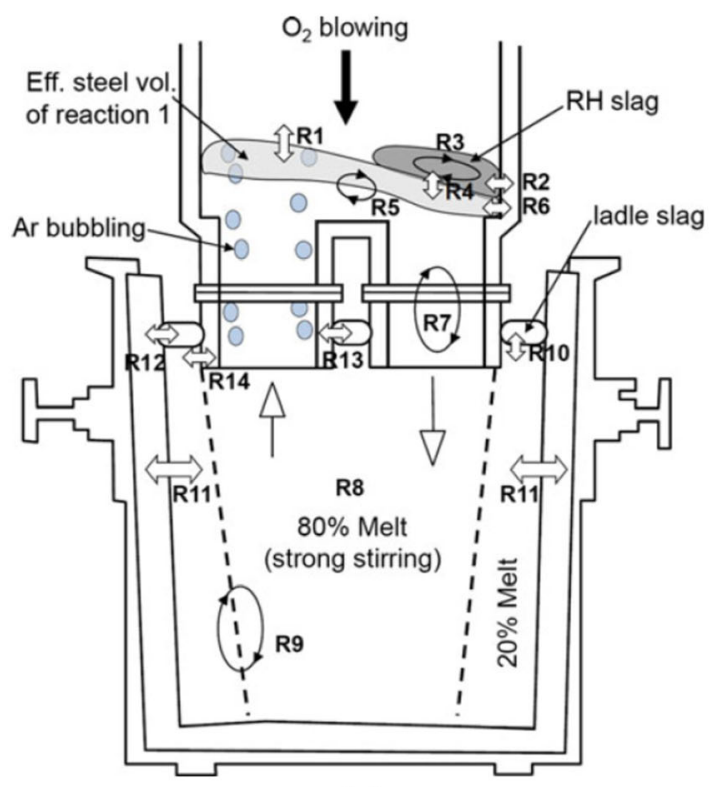

(a)

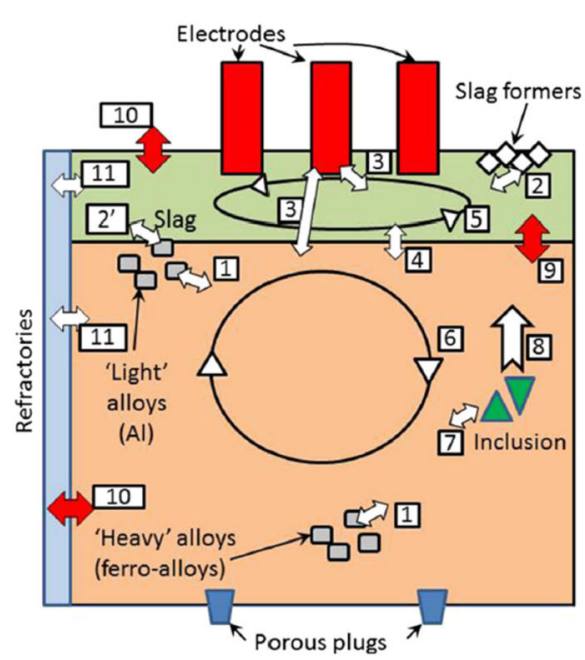

(b)

Fig. 20-Schematic diagram of the reaction zones in the (a) RH degasser and (b) LF. Reprinted from Refs. [315 and 317 ].

VJRG applied the EERZ model to simulate the operation results of LF at ArcelorMittal Dofasco published by Graham and Irons. ${ }^{[299]}$ Both the compositions of steel and slag and the temperature of molten steel were well calculated, from which the variation of inclusions during LF operation was predicted, as shown in Figure 21. ${ }^{[317]}$ The amount of $\mathrm{Al}_{2} \mathrm{O}_{3}$ inclusion decreases quickly due to the floatation and is captured by slag, and it is transformed to calcium aluminates and spinel inclusions. In this simulation, they assumed a constant inclusion removal rate of 6 pet $\min ^{-1}(=0.1$ pct $\mathrm{s}^{-1}$ ). The overall inclusion trajectory and composition of inclusions are qualitatively acceptable even though there are some discrepancies between predicted and measured results.

The EERZ model in conjunction with the FACTSAGE Macro Processing function has been adopted by several research groups after some modifications. The Hanyang University Research Group (HURG) applied the modified EERZ model, i.e., the Refractory-Slag-Metal-Inclusion (ReSMI) multiphase reactions model, to predict the inclusion evolution in molten steel. Even though the ReSMI model was developed based on the laboratory scale experiments, HURG performed separate experiments for the desulfurization kinetics to deduce the mass transfer coefficients of components in the metal and slag phase independently. They estimated the reaction zone volume of metal and slag phase per unit calculation step $\left(V_{M}^{t}\right.$ and $\left.V_{S}^{t}\right)$ as follows ${ }^{[113]}$ :

$$
\begin{gathered}
V_{M}^{t}=\frac{W_{M}^{t}}{\rho_{M}}=d_{M} \cdot A \cdot \Delta t \quad\left(\mathrm{~m}^{3}\right) \\
d_{M}=1.0 \times 10^{-4} \quad\left(\mathrm{~m} \mathrm{~s}^{-1}\right) \\
V_{S}^{t}=\frac{W_{S}^{t}}{\rho_{S}}=d_{S} \cdot A \cdot \Delta t \quad\left(\mathrm{~m}^{3}\right) \\
d_{S}=2.5 \times 10^{-5} \quad\left(\mathrm{~m} \mathrm{~s}^{-1}\right)
\end{gathered}
$$

where the subscripts $M$ and $S$ represent the metal and slag phases, respectively. $W^{t}$ is the reaction zone mass per unit step $(\mathrm{g}), d$ is the effective reaction zone depth of each phase per time interval, $\rho$ is the density of each phase $\left(\mathrm{g} \mathrm{m}^{-3}\right)$, and $A$ represents the interface area between the metal and slag phases $\left(\mathrm{m}^{2}\right)$. Furthermore, from the $\mathrm{MgO}$ dissolution kinetics from the refractory to slag phase, the mass transfer coefficient of $\mathrm{MgO}$ in the slag phase was deduced as follows ${ }^{[113]}$.

$$
k_{\mathrm{MgO}}=5.0 \times 10^{-6} \quad\left(\mathrm{~m} \mathrm{~s}^{-1}\right)
$$

The variation of $\mathrm{MgO}$ content in the slag is significantly important, because the transfer of $\mathrm{Ca}$ and $\mathrm{Mg}$ 


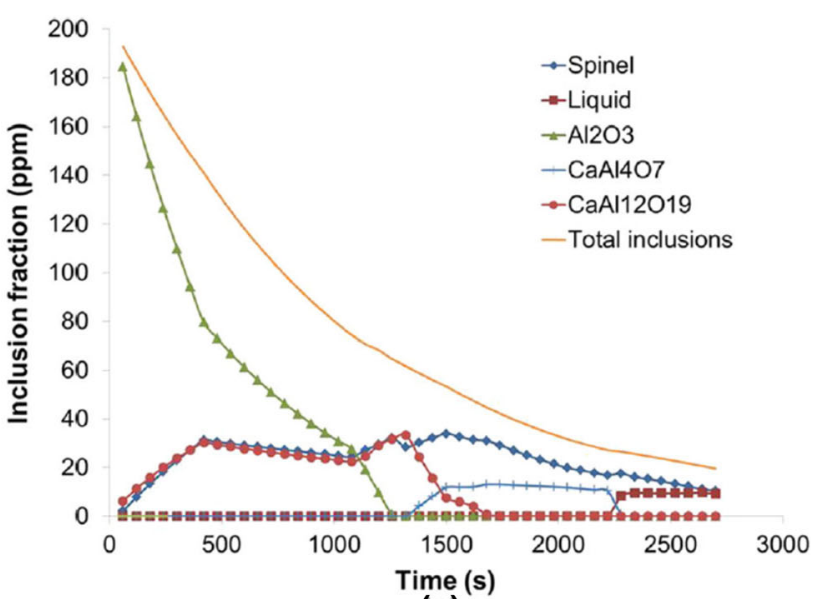

(a)

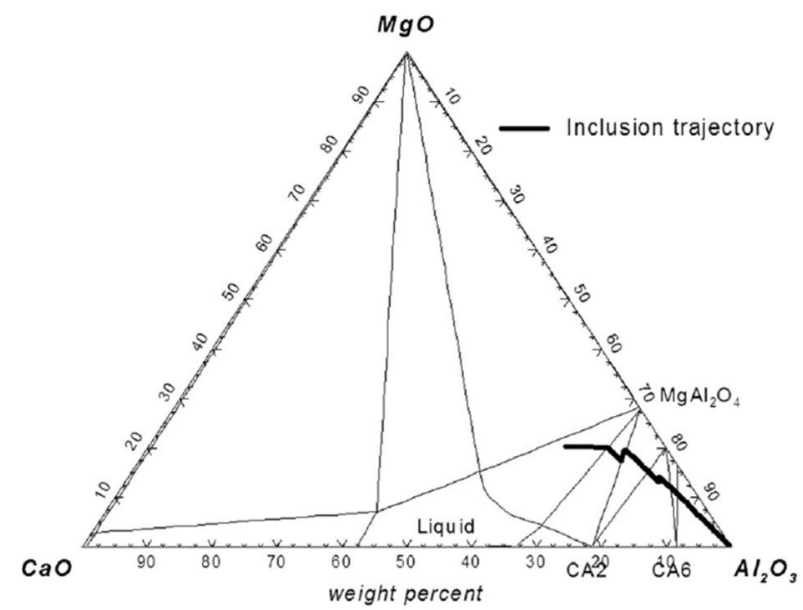

(b)

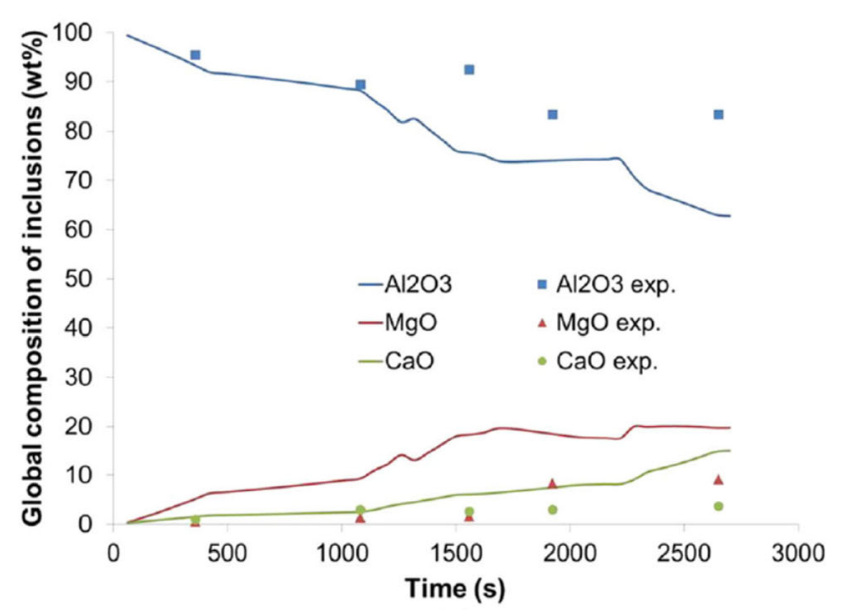

(c)

Fig. 21-Simulated chemistry change in nonmetallic inclusions: (a) variation of the amounts of different types of inclusions, $(b)$ overall calculated inclusion trajectory plotted in the $\mathrm{CaO}-\mathrm{MgO}-\mathrm{Al}_{2} \mathrm{O}_{3}$ phase diagram at $1873 \mathrm{~K}\left(1600{ }^{\circ} \mathrm{C}\right)$, and $(c)$ overall inclusion composition change with time along with the plant data. Reprinted from Ref. [317].

from the top slag to the Al-killed steel can modify the composition of inclusions based on the following reactions ${ }^{[8,112,113]}$ :

$$
\begin{gathered}
3(\mathrm{MgO})_{\text {slag }}+2[\mathrm{Al}]=3[\mathrm{Mg}]+\left(\mathrm{Al}_{2} \mathrm{O}_{3}\right)_{\text {slag }} \\
3(\mathrm{CaO})_{\text {slag }}+2[\mathrm{Al}]=3[\mathrm{Ca}]+\left(\mathrm{Al}_{2} \mathrm{O}_{3}\right)_{\text {slag }} \\
\left(\mathrm{Al}_{2} \mathrm{O}_{3}\right)_{\text {inclusion }}+[\mathrm{Mg}]+[\mathrm{O}]=\mathrm{MgAl}_{2} \mathrm{O}_{4}(\mathrm{~s}) \\
{[\mathrm{Ca}]+1 / 3\left(\mathrm{Al}_{2} \mathrm{O}_{3}\right)_{\text {spinel_inclusion }}} \\
=(\mathrm{CaO})_{\mathrm{CAM} \_ \text {inclusion }}+2 / 3[\mathrm{Al}]
\end{gathered}
$$

For the simulation, the EXCEL interface was used and thermodynamic equilibria of all reaction zones were calculated adiabatically using FACTSAGE with the FToxid and FTmisc database. The predicted compositions of steel, i.e., aluminum, silicon, and oxygen, are shown in Figure 22 with the measured data. ${ }^{[93,112,113]}$ The predicted results correspond strongly with the measured data. The trajectory of the simulated composition of the inclusions is plotted in the $\mathrm{CaO}-\mathrm{Al}_{2} \mathrm{O}_{3}-\mathrm{SiO}_{2}-10 \mathrm{MgO}$ (mass pet) phase diagram at $1873 \mathrm{~K}\left(1600{ }^{\circ} \mathrm{C}\right)$, as shown in Figure $23 .{ }^{[93,112,113]}$

The changes in the $\mathrm{CaO} / \mathrm{Al}_{2} \mathrm{O}_{3}(=\mathrm{C} / \mathrm{A})$ ratio of the ladle slag on the inclusion evolution in the $\mathrm{Mn}$ and $\mathrm{V}$ alloyed steel were successfully simulated by HURG, as shown in Figure 24. ${ }^{[92]}$ The symbols in Figure 24(a) represent the $\mathrm{Mg}$ and $\mathrm{Ca}$ traces in molten steel according to the reaction time calculated using the ReSMI model. Alumina inclusion is stable at the initial stage of the reaction. When the $C / A$ ratio of the slag is lower than 1.2, the stable phase changes from alumina to spinel within 3 minutes and still remains in the spinel predominance area through the entire holding time, i.e., 90 minutes $(\mathrm{Ca}<1 \mathrm{ppm})$. However, when the $C / A$ ratio of the slag is 1.8 or 2.3 , the stable phase rapidly changes from alumina to spinel within 1 minute and the traces get into the liquid inclusion predominance area $(\mathrm{Ca} \geq 1$ $\mathrm{ppm})$ and remain there for 90 minutes $(\mathrm{Ca} \cong 2 \mathrm{ppm})$. Finally, when the $C / A$ ratio of the slag is 3.3 , the $\mathrm{Ca}$ content is predicted to exceed the threshold of the spinel-liquid transition within 3 minutes, but the $\mathrm{Mg}$ content also exceeds $10 \mathrm{ppm}$ at about 15 minutes; thus, the evolution trace crosses the phase boundary from liquid oxide to the $\mathrm{MgO}$ predominance area. The preceding prediction of inclusion evolution according to the slag composition and reaction time is in good agreement with the experimental findings, as shown in Figure 24(b).

The EERZ model was also employed to predict the inclusion evolution in Si-Mn-killed steel by the Carnegie Mellon University Research Group (CMRG). ${ }^{[318]}$ They used the FACTSAGE macrofunction and relevant database (FToxid an FTmisc) to predict the inclusion evolution by considering $\mathrm{Al}$ pickup into the $\mathrm{Si}-\mathrm{Mn}-$ killed steel by reacting with the $\mathrm{MgO}$-saturated $\mathrm{CaO}$ $\mathrm{Al}_{2} \mathrm{O}_{3}-\mathrm{MgO}-\mathrm{SiO}_{2}$ slag, as given in Eq. [25]. ${ }^{[8,77-81,318]}$ 


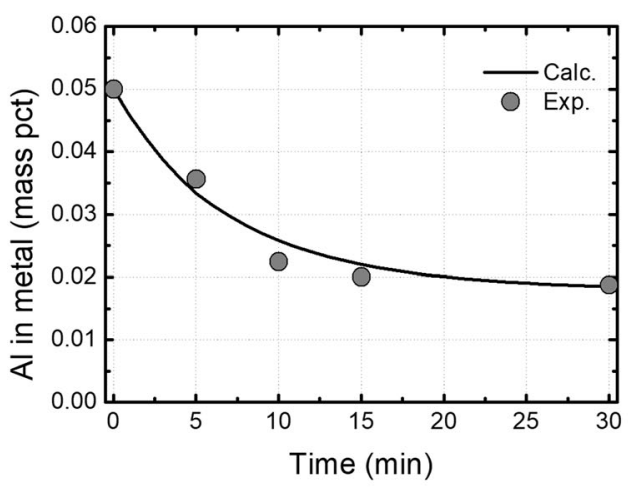

(a)

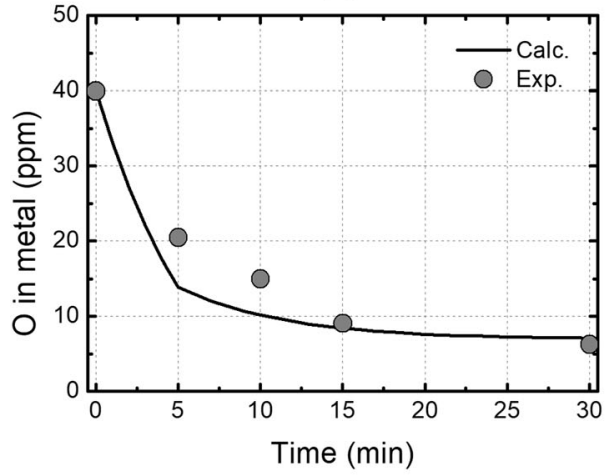

(c)

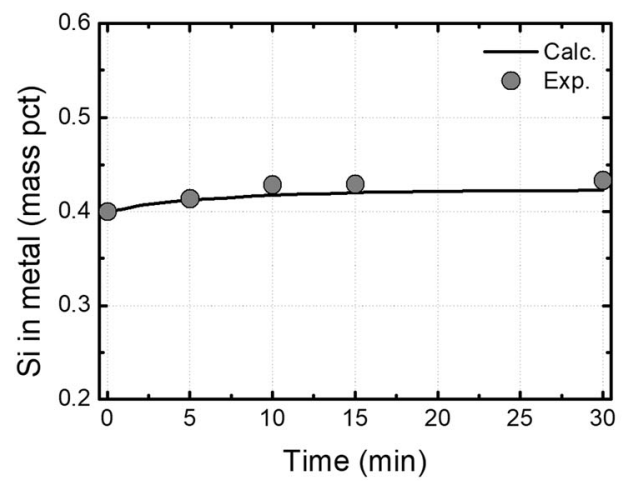

(b)

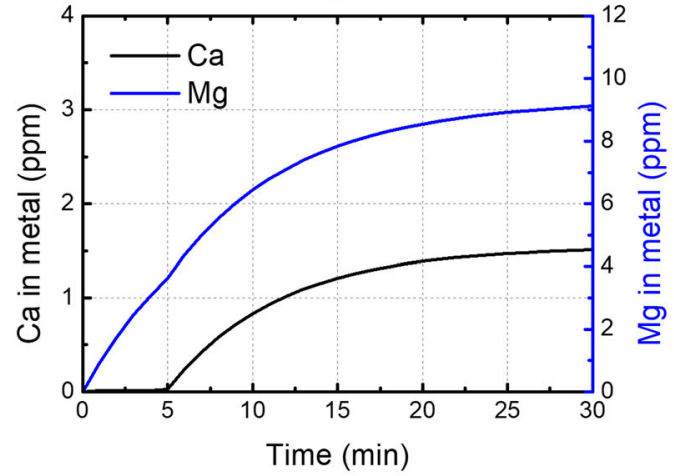

(d)

Fig. 22 - Calculated and measured results of the composition of molten steel: $(a)$ aluminum, $(b)$ silicon, $(c)$ oxygen, and $(d)$ calcium and magnesium at $1873 \mathrm{~K}\left(1600{ }^{\circ} \mathrm{C}\right)$. Reprinted from Ref. [113].

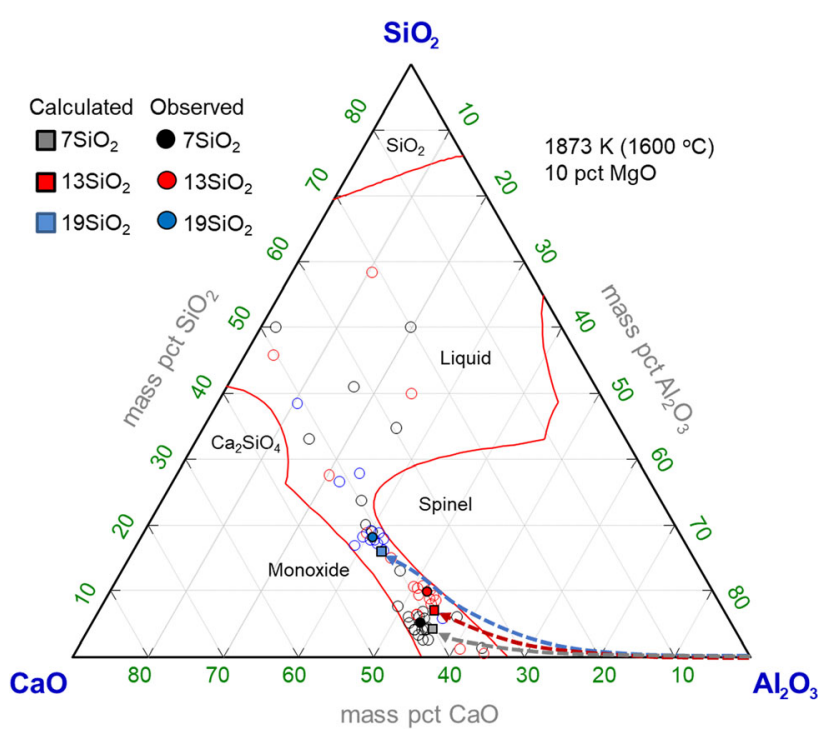

Fig. 23-Trajectory of the calculated composition of the inclusions and average measured composition of inclusions in Al-killed steel reacted with slag with different $\mathrm{SiO}_{2}$ contents at $1873 \mathrm{~K}\left(1600{ }^{\circ} \mathrm{C}\right)$. Reprinted from Ref. [112].

$$
3[\mathrm{Si}]+2\left(\mathrm{Al}_{2} \mathrm{O}_{3}\right)_{\text {slag }}=3\left(\mathrm{SiO}_{2}\right)_{\text {slag }}+4[\mathrm{Al}]
$$

The dissolved $\mathrm{Al}$ can react with the $\mathrm{MnO}-\mathrm{SiO}_{2}$ deoxidation product to form $\mathrm{Al}_{2} \mathrm{O}_{3}$-rich inclusions as follows: ${ }^{[8,77-81,318]}$

$$
\begin{gathered}
4[\mathrm{Al}]+3\left(\mathrm{SiO}_{2}\right)_{\text {inclusion }}=3[\mathrm{Si}]+2\left(\mathrm{Al}_{2} \mathrm{O}_{3}\right)_{\text {inclusion }} \\
2[\mathrm{Al}]+3(\mathrm{MnO})_{\text {inclusion }}=3[\mathrm{Mn}]+\left(\mathrm{Al}_{2} \mathrm{O}_{3}\right)_{\text {inclusion }}
\end{gathered}
$$

From the laboratory scale experiments, CMRG deduced the following mass transfer coefficient of metal phase to fit their experimental data for the Al pickup rate according to Eq. [25]. For the slag phase mass transfer coefficient $\left(k_{s}\right)$, Eq. [11a] was adopted. ${ }^{[318]}$

$$
k_{m}=8 \times 10^{-6} \quad\left(\mathrm{~m} \mathrm{~s}^{-1}\right)
$$

The calculation flow is similar to that performed by VJRG and HURG. However, because they used $\mathrm{MgO}$-saturated slag, the slag-refractory and steel-refractory reactions were not considered in their model. The changes in inclusion composition for measured 


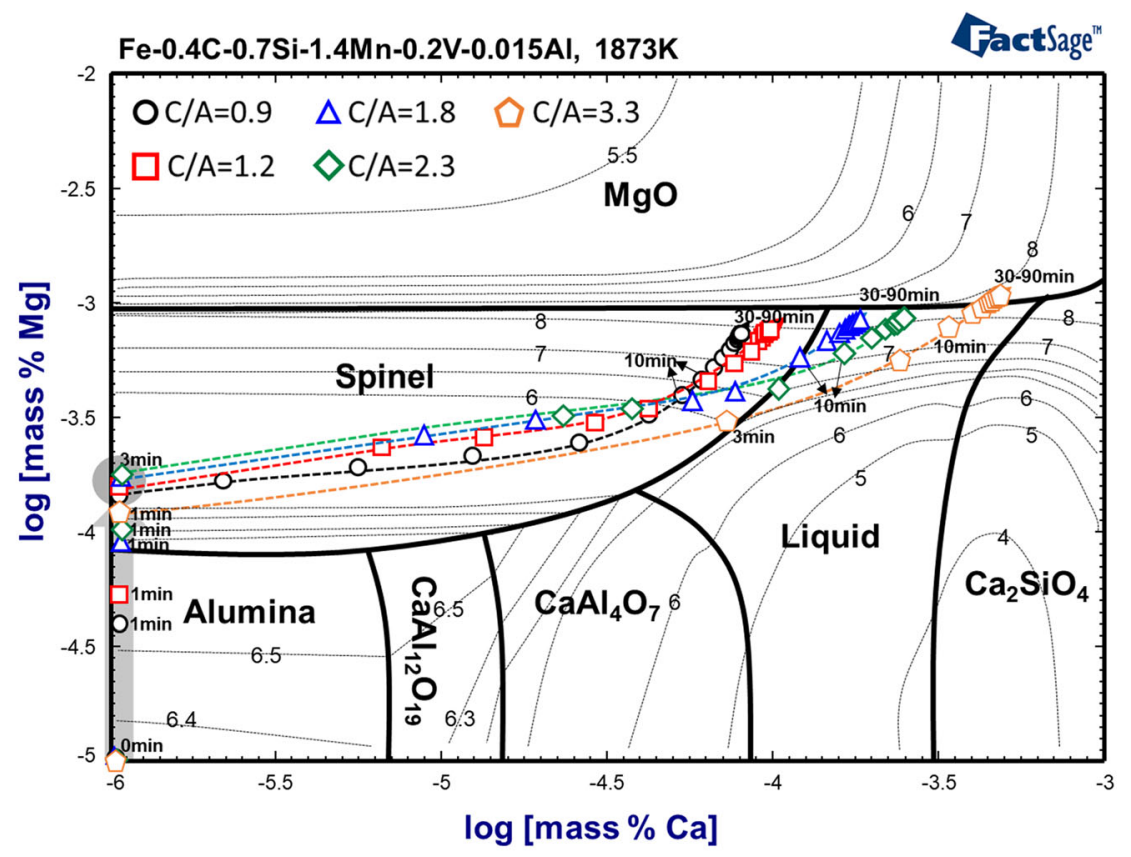

(a)

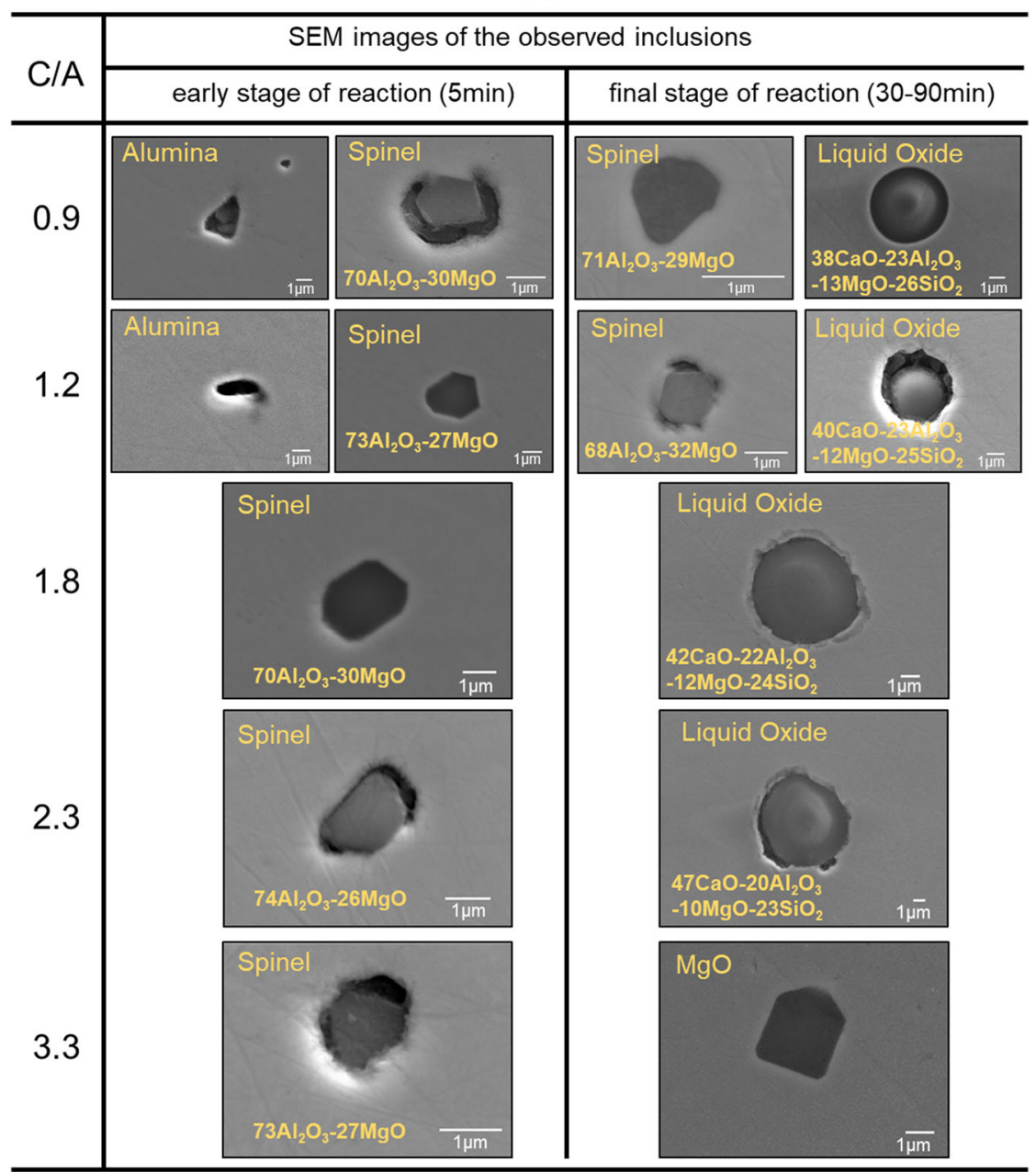

(b)

Fig. 24-(a) Trajectory of inclusions shown in the phase stability diagram with iso-oxygen contours and (b) SEM image of inclusions at the early $(5 \mathrm{~min})$ and final (30 to $90 \mathrm{~min}$ ) stages of the refining reaction in the $\mathrm{Fe}-0.4 \mathrm{C}-0.7 \mathrm{Si}-1.4 \mathrm{Mn}-0.2 \mathrm{~V}-0.015 \mathrm{Al}$ (mass pet) melt containing $\mathrm{Mg}$ and $\mathrm{Ca}$ at $1873 \mathrm{~K}\left(1600^{\circ} \mathrm{C}\right)$. Reprinted with permission from Ref. [92]. 

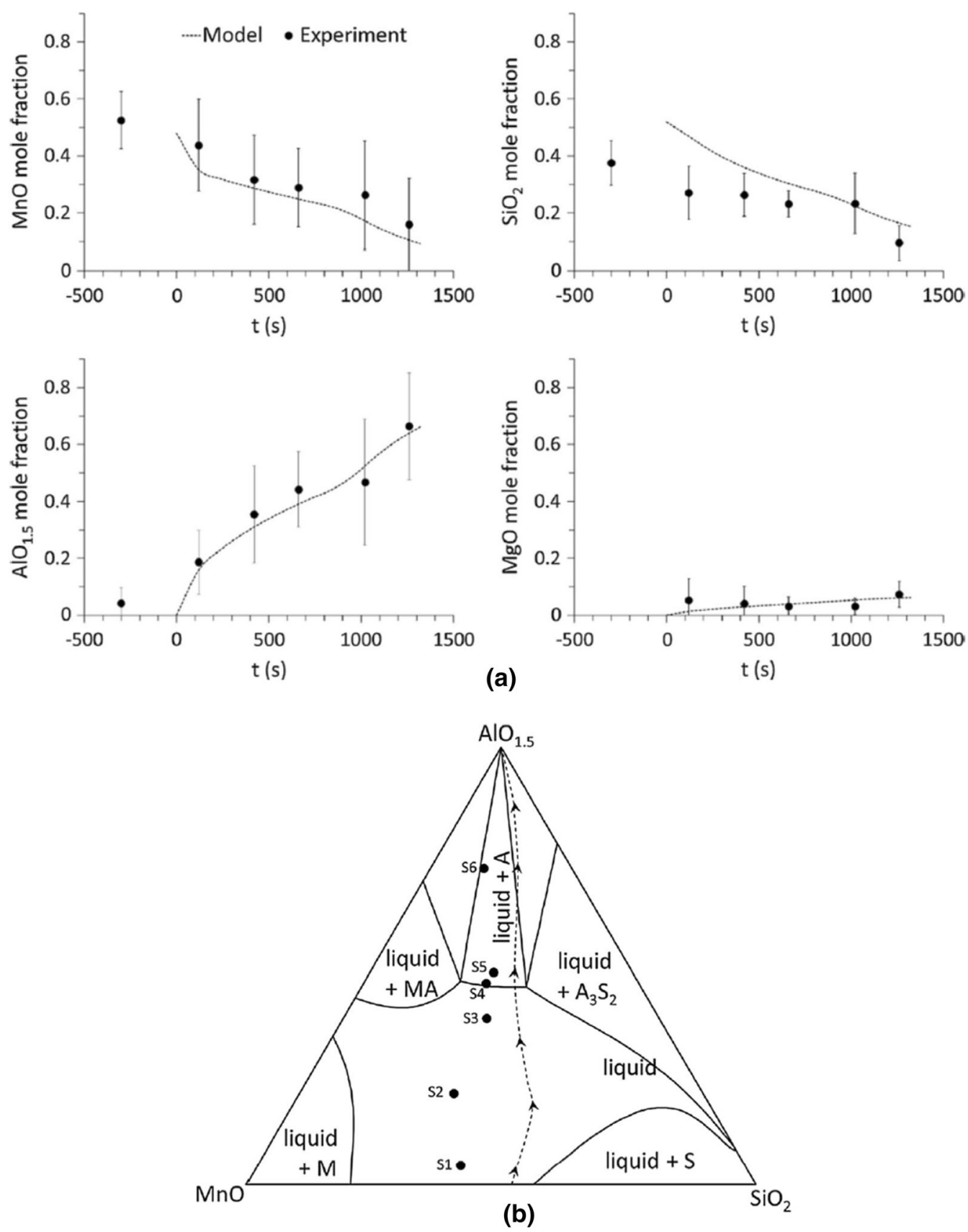

Fig. 25-(a) Change in inclusion composition with time: measured (data points) and modeled (broken lines). (b) Isothermal section of the $\mathrm{MnO}-\mathrm{SiO}_{2}-\mathrm{Al}_{2} \mathrm{O}_{3}$ phase diagram at $1873 \mathrm{~K}\left(1600{ }^{\circ} \mathrm{C}\right)$ together with the inclusion composition trajectories: modeled (broken line) and measured (data points). Reprinted from Ref. [318].

and modeled are compared in Figure $25^{[318]}$ A decreasing tendency of $\mathrm{MnO}$ and $\mathrm{SiO}_{2}$ and an increasing tendency of $\mathrm{Al}_{2} \mathrm{O}_{3}$ are well predicted even though there is a slight overestimation of $\mathrm{SiO}_{2}$ content and an underestimation of $\mathrm{MnO}$ content. A small extent of an $\mathrm{MgO}$ increase was also predicted, which originated from the slag-metal reaction. ${ }^{[8,77-81,318]}$ Using high-temperature confocal scanning laser microscopy (HT-CSLM), they confirmed the transformation of liquid $\mathrm{Mn}$-silicate to solid $\mathrm{Al}_{2} \mathrm{O}_{3}$-rich inclusions.
Later, CMRG performed the experiments to investigate the influence of $\mathrm{MgO}$ refractory on an increase of $\mathrm{MgO}$ content in alumina inclusions in Al-killed steel under static conditions. They developed the inclusion evolution model by employing several fitting parameters such as the inclusion floatation (removal) rate (called $\beta_{1,2}$ parameters) and the mass transfer coefficient in metal phase $\left(k_{m}\right) \cdot{ }^{[319]}$

$$
\beta_{1}=0.007 \text { to } 0.009 \quad\left(\mathrm{~s}^{-1}\right) \text { at } t \leq 180 \text { seconds }[29 \mathrm{a}]
$$




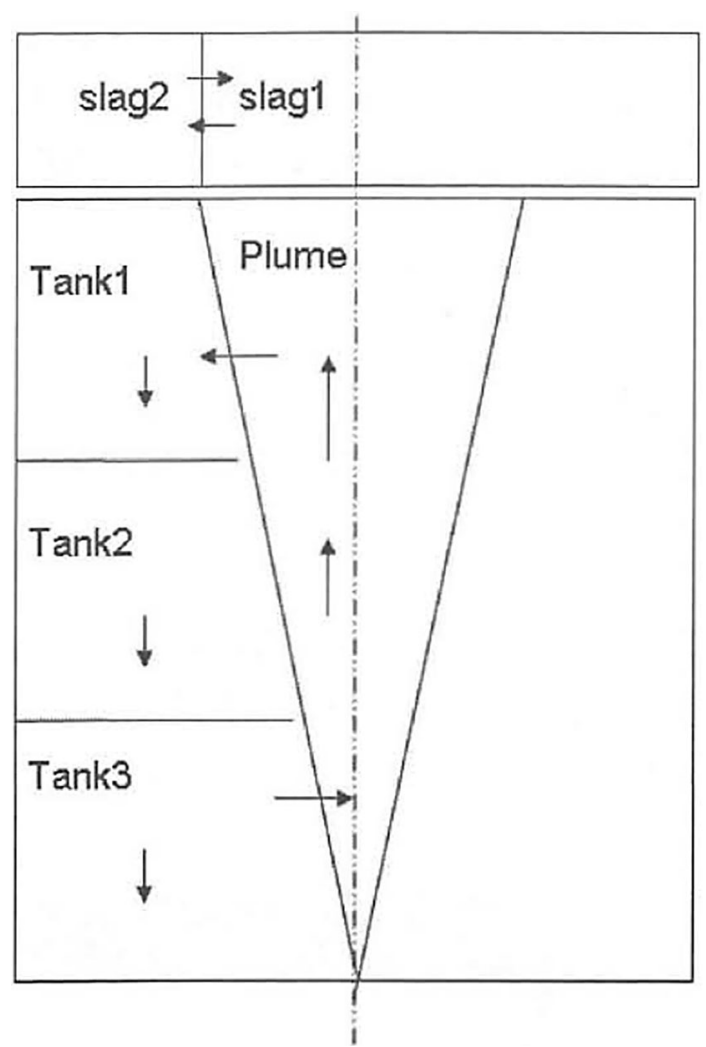

Fig. 26-Schematics of the liquid TSR model for the ladle. Reprinted with permission from Ref. [325].

$$
\begin{gathered}
\beta_{2}=0.0009 \text { to } 0.001 \quad\left(\mathrm{~s}^{-1}\right) \text { at } t>180 \text { seconds } \\
k_{m}=3.2 \times 10^{-6} \text { to } 5.5 \times 10^{-5} \quad\left(\mathrm{~m} \mathrm{~s}^{-1}\right)
\end{gathered}
$$

However, because the experiments were performed under static condition without slag (even though they considered small amounts of the $\mathrm{CaO}-\mathrm{Al}_{2} \mathrm{O}_{3}-\mathrm{MgO}$ oxide as impurity in the refractory), the $k_{m}$ value in Eq. [30] is different from Eq. [28], which was deduced from the experiments with the $\mathrm{CaO}-\mathrm{Al}_{2} \mathrm{O}_{3}-\mathrm{MgO}_{\text {sat }}-\mathrm{SiO}_{2}$ slag under dynamic conditions using an induction furnace. Also, they used different fitting parameters when they simulated the industrial ladle processing as follows $\left(k_{s}=0.1 k_{m}\right) \cdot{ }^{[319]}$

$$
\begin{gathered}
k_{m}=0.002 \quad\left(\mathrm{~m} \mathrm{~s}^{-1}\right) \\
\beta=0.0026 \quad\left(\mathrm{~s}^{-1}\right)
\end{gathered}
$$

Nevertheless, it is meaningful that CMRG tried to simulate the effect of ladle glaze on the evolution of inclusions in molten steel, which had never been tried before. The experimental observations for the influence of ladle glaze on the evolution of inclusions are available elsewhere. ${ }^{[320-324]}$

\section{Tank Series Recirculation Model}

An alternative approach was developed by the Technische Universität Bergakademie Freiberg Research Group. ${ }^{[325,326]}$ They employed the tank series recirculation (TSR) model, which was developed by several researchers, ${ }^{[131,327-329]}$ to simulate the mixing phenomena in a gas-stirred ladle. The TSR model was combined with thermochemical computations by accepting the SIMUSAGE ${ }^{\ddagger}$ in conjunction with the

${ }^{\ddagger}$ SIMUSAGE is a trademark of GTT-Technologies, Germany and ThermFact Ltd., Canada.

FACTSAGE thermodynamic database. ${ }^{[325,326]}$ They considered four key reactions: (1) mixing in the gas-stirred ladle, (2) slag-metal reactions, (3) separation (removal) of inclusion through the slag phase, and (4) effect of ladle lining (MgO-C) dissolution on slag and steel chemistry. The related parameters to simulate the inclusion evolution during the ladle refining process are as follows:

$$
\begin{gathered}
r_{M}=2800 \quad\left(\mathrm{~kg} \mathrm{~s}^{-1}\right) \quad(\text { for medium Ar flow rate }) \\
k_{m}\left(k_{S T} \text { in original study }\right)=0.002 \quad\left(\mathrm{~m} \mathrm{~s}^{-1}\right) \\
k_{S}\left(k_{S L} \text { in original study }\right)=0.001 \quad\left(\mathrm{~m} \mathrm{~s}^{-1}\right)
\end{gathered}
$$

$$
\begin{gathered}
k_{\mathrm{MgO}-\mathrm{C}(\text { steel_lining })}=0.0005 \quad\left(\mathrm{~kg} \mathrm{~m}^{-2} \mathrm{~s}^{-1}\right) \\
k_{\mathrm{MgO}-\mathrm{C}(\text { slag_lining })}=0.001 \quad\left(\mathrm{~kg} \mathrm{~m}^{-2} \mathrm{~s}^{-1}\right) \\
T=1650-\frac{0.144 \mathrm{t}}{60}-8.689 \sqrt{\frac{t}{60}} \quad(\operatorname{degC})
\end{gathered}
$$

where $r_{M}$ is the mass recirculation rate; $k_{m}$ and $k_{s}$ are the mass transfer coefficient of metal and slag phases, respectively; and $k_{\mathrm{MgO}-\mathrm{C}(\text { steel_lining) }}$ and $k_{\mathrm{MgO}-\mathrm{C} \text { (slag_lining) }}$ are the refractory dissolution rate in the steel and slag lining area, respectively. As schematically shown in Figure $26,{ }^{[325]}$ the vertical half section of the steel bath was assumed to consist of a series of four closed tanks (including an upward flowing plume area) and the top slag was modeled using two tanks. Also, it was assumed that the composition and temperature are homogeneous in each tank and the steel-inclusion reaction reaches local equilibrium. They considered the different separation rates for several inclusion groups based on the HT-CSLM investigations. Thus, the separation rates (percentage) of MA spinel and liquid inclusions in one calculation step (5 seconds) were assumed to be $0.03 \mathrm{pct}$ $\left(=0.006 \mathrm{pct} \mathrm{s}^{-1}\right)$ and $0.05 \mathrm{pct}\left(=0.01 \mathrm{pct} \mathrm{s}^{-1}\right)$, respectively. The separation rate of $\mathrm{Al}_{2} \mathrm{O}_{3}$ and $\mathrm{Al}_{2} \mathrm{O}_{3}$-rich $\mathrm{Ca}$-aluminate inclusions was assumed to be 20 pct per step $\left(=4\right.$ pct s$\left.^{-1}\right)$ during the initial 10 minutes, after which it was assumed to be 5 pet per step $\left(=1\right.$ pct s$\left.^{-1}\right)$. 

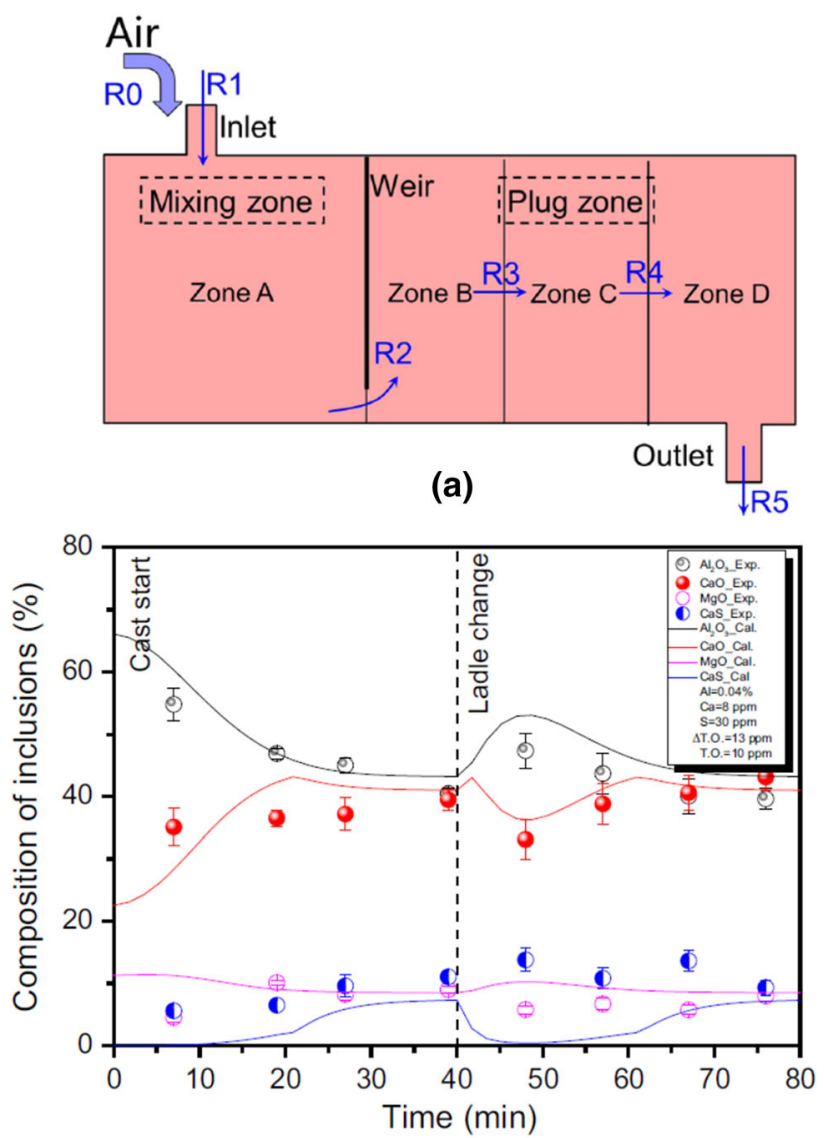

(b)

Fig. 27-(a) Schematic diagram of reaction zones in tundish and $(b)$ comparison of the predicted and experimental results of inclusion compositions in Ca-treated Al-killed steels in zone D. Reprinted from Ref. [99].

However, even though they mentioned the recirculation rate of the metal and slag phase separately, it is uncertain whether they used the same value (Eq. [33]) to calculate the mixing rate in the metal and slag phase. Moreover, the mass transfer coefficient of the slag phase is half the level of the metal phase mass transfer coefficient, which seems to be rather exaggerated compared to other researchers' considerations (Eqs. [4] and [5], [7] and [8], and [10] and [11]). Consequently, although they considered slag-metal, refractory-slag, refractory-metal, and metal-inclusion reactions as elementary reaction steps, including the inclusion removal rates, there are several fitting parameters to be optimized in specific industrial operation conditions.

\section{KINETIC MODEL FOR INCLUSION EVOLUTION IN CC TUNDISH BY CONSIDERING REOXIDATION PHENOMENA}

The EERZ model was also employed to simulate the inclusion evolution behavior in tundish including reoxidation phenomena due to atmosphere or reducible oxide in tundish slag. Ren et al. ${ }^{[99]}$ predicted the inclusion composition in Ca-treated Al-killed steel in

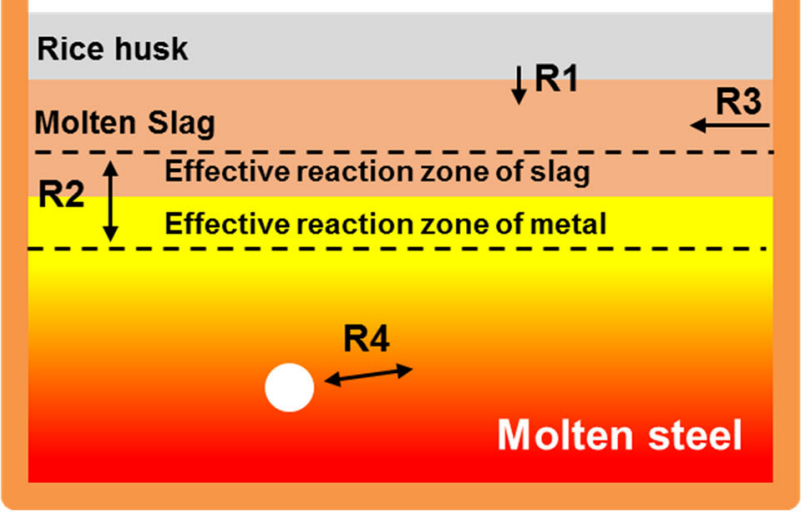

(a)

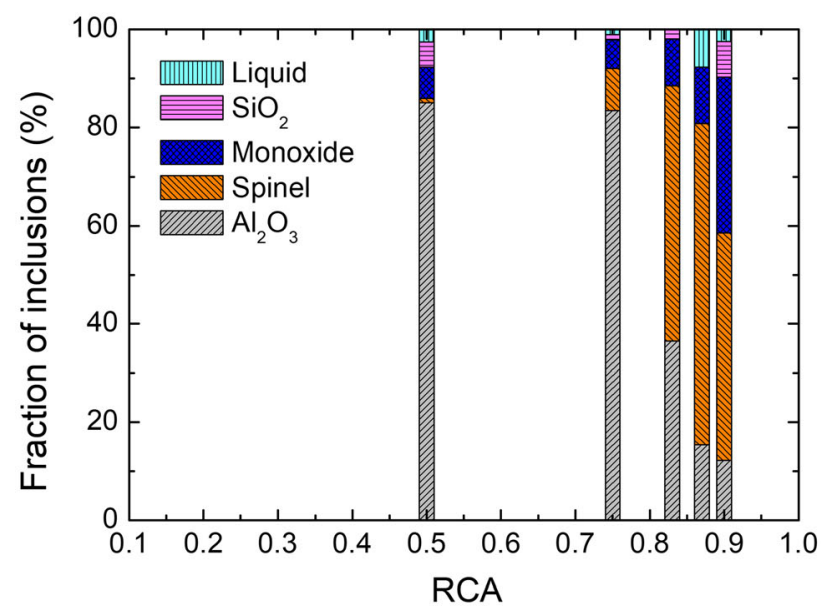

(b)

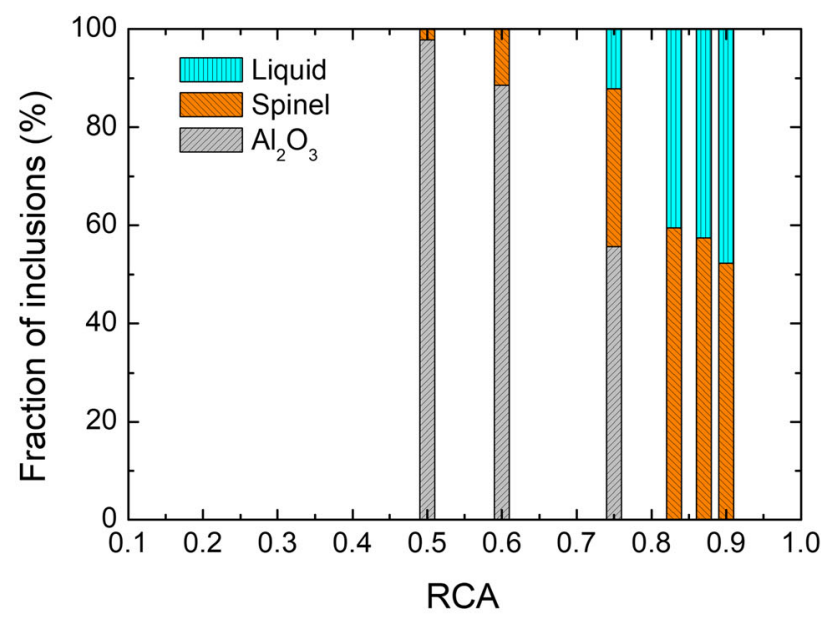

(c)

Fig. 28-(a) Schematic of the dissolution of RHA (R1), the slag-metal reaction ( $\mathrm{R} 2)$, the refractory $(\mathrm{MgO})$-slag reaction ( $\mathrm{R} 3)$, and the inclusion-steel reaction (R4) in the model system employed; (b) the experimental and (c) the calculated changes to the relative fraction of the inclusions in molten steel at $5 \mathrm{~min}$ as a function of RCA. Reprinted from Refs. [330] and [332].

tundish ( 25 ton) by considering the reoxidation by the air at an initial teeming stage (cast start) and ladle (115 ton) change period based on several assumptions: (1) the 


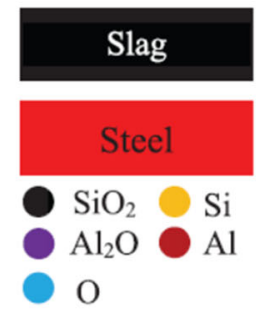

(1) Before contact

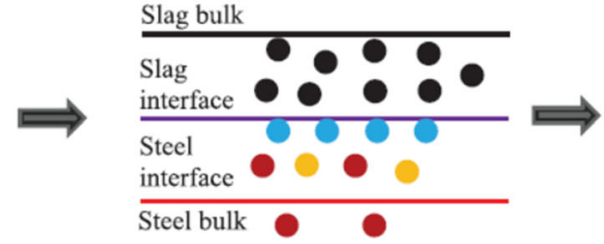

(2) Immediate release of $\mathrm{O}$ and $\mathrm{Si}$ from $\mathrm{SiO}_{2}$ decomposition at the interface after a contact has been established. Due to the $\mathrm{SiO}_{2}$ decomposition, its concentration at the interface decreases. The $\mathrm{O}$ and $\mathrm{Si}$ amounts in the steel interface increase.

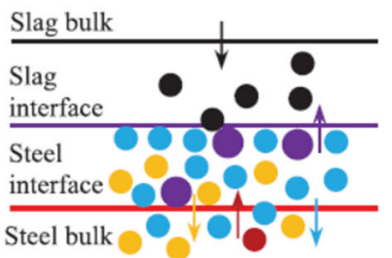

(6) The supply of $\mathrm{SiO}_{2}$ from slag becomes slow and its mass transfer is reduced by the blockage of the formed alumina at interface. The $\mathrm{O}$ desorption and $\mathrm{O}$ reaction with $\mathrm{Al}$ decrease the free $\mathrm{O}$ in steel. Thus, oxygen content at interface decreases.

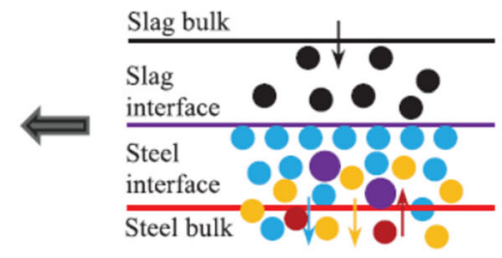

(5) Supply of $\mathrm{SiO}_{2}$ from bulk is high, while aluminum reaction with oxygen also becomes strong. A peak value of the $\mathrm{O}$ content at the interface is observed.

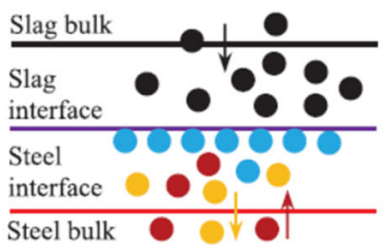

(3) $\mathrm{SiO}_{2}$ diffuses from slag bulk to the slag interface layer, and Si diffuse into the steel bulk. Oxygen tends to stay in the interfacial region. Al reaction with $\mathrm{O}$ did not happen or the reaction is very weak.

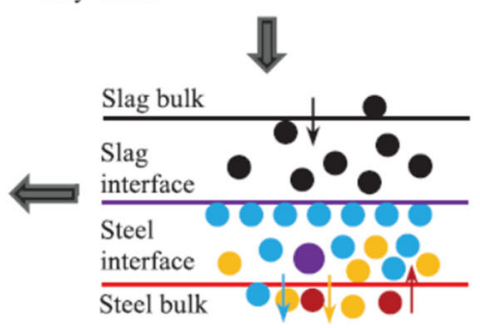

(4) Oxygen content is increasing in the steel sub-interface. Aluminum reaction increases and alumina product formed. Oxygen desorption from the steel sub-interface to the bulk occurs.

Fig. 29-Microscopic view of the mechanism illustrations of the dynamic behavior at the steel-slag interface under the effect of chemical reactions. Reprinted with permission from Ref. [336].

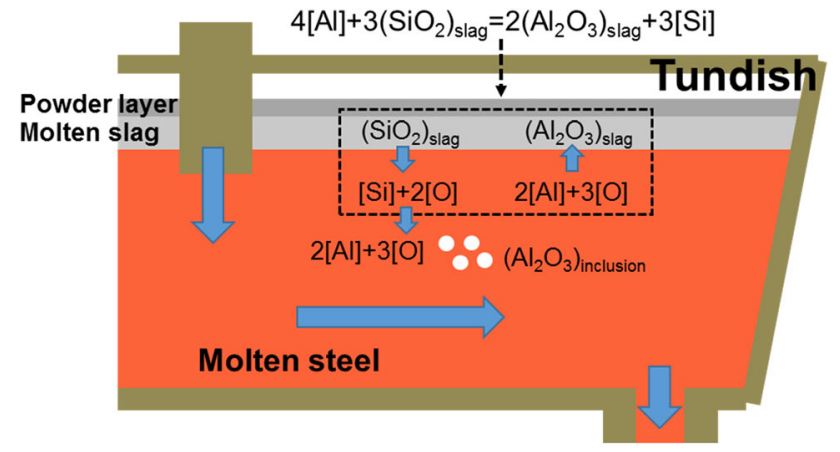

Fig. 30-Macroscopic view of the scheme for the reoxidation phenomena originated from the slag-metal interfacial reactions in tundish. Reprinted from Ref. [332].

compositions of steel and inclusions in each reaction zone are homogenous; (2) the steel/inclusion reaction is assumed to reach equilibrium; (3) the temperature can be maintained at a certain fixed temperature; (4) the removal of inclusions to the slag, the slag/steel reaction, and the influence of refractory are not considered; and (5) the effect of the dead zone on the steel/inclusion reaction is ignored. The schematic diagram of reaction zones in tundish and the comparison of the predicted and experimental results of inclusion compositions in Ca-treated Al-killed steels in zone $\mathrm{D}$ are shown in Figure 27. ${ }^{[99]}$ An abrupt increase in $\mathrm{Al}_{2} \mathrm{O}_{3}$ content in the inclusions at the cast start and ladle change period corresponded strongly with the well-known reoxidation phenomena originated from air.
Alternatively, the influence of reoxidation due to slag-metal reaction (including the dissolution of $\mathrm{SiO}_{2}$-rich rice hush ash (RHA) into the liquid slag pool) on the inclusion evolution in Al-killed steel in tundish was simulated by HURG. ${ }^{[330]}$ It was assumed that the $\mathrm{SiO}_{2}$ in the RHA layer could be rapidly dissolved into the molten slag layer (R1 in Figure 28(a)) from the fundamental study of Feichtinger et al. ${ }^{[331]}$ for silica dissolution kinetics in the $\mathrm{CaO}-\mathrm{SiO}_{2}-\mathrm{Al}_{2} \mathrm{O}_{3}$ slag. Therefore, it was assumed that RHA is completely dissolved into molten slag layer before calculating the oxidation-reduction reactions at the slag/metal interface (R2). ${ }^{[330-332]}$

The effect of the mixing ratio of calcium aluminate flux (CA-flux) to [rice husk ash (RHA) + CA-flux] (= RCA) on the mass fraction (population) of oxide inclusions in molten steel at an early stage of the reaction (e.g., 5 minutes) is shown in Figures 28(b) and (c). ${ }^{[330]}$ In the simulation, the effective reaction zone depth of the metal and slag phase was chosen as follows (for $\mathrm{MgO}$ dissolution rate, Eq. [20] was used):

$$
\begin{gathered}
d_{M}=2.0 \times 10^{-4} \quad\left(\mathrm{~m} \mathrm{~s}^{-1}\right) \\
d_{S}=3.5 \times 10^{-5} \quad\left(\mathrm{~m} \mathrm{~s}^{-1}\right)
\end{gathered}
$$

In Figures 28(b) and (c), it is interesting that the calculations reveal a similar tendency for inclusion evolution as a function of RCA as that obtained from the experiment. The relative fraction of $\mathrm{Al}_{2} \mathrm{O}_{3}$-rich inclusions dramatically decreased and that of spinel-type 
inclusions was evaluated when the RCA was over 0.8 . The spinel-type inclusions were formed from the reaction between $\mathrm{Al}_{2} \mathrm{O}_{3}$ inclusions and magnesium that originated from the slag phase, as given in Eqs. [21] and [23].

A similar trial for the inclusion evolution during the reoxidation of $\mathrm{Al}-\mathrm{Ti}$ - containing steel by the $\mathrm{CaO}$ $\mathrm{SiO}_{2}-\mathrm{Al}_{2} \mathrm{O}_{3}-\mathrm{MgO}$ slag was performed by Ren et al. ${ }^{[333]}$ They employed $k_{m}$ as given in Eq. [10] and took Eq. [11a] for $k_{s}$. The validity of the model was proved by comparing the modeling results to the experimental data measured by Park et al., ${ }^{[334]}$ from which the floatation rate of inclusion was also deduced to $0.05 \mathrm{pct} \mathrm{s}^{-1}$. It was found that the inclusion amounts formed due to reoxidation by slag-metal reactions were not significantly affected by changing the $\mathrm{CaO} / \mathrm{Al}_{2} \mathrm{O}_{3}$ ratio, while they were significantly reduced by increasing the $\mathrm{CaO} /$ $\mathrm{SiO}_{2}$ ratio of the slag. ${ }^{[333]}$ This is mainly because of a decrease in $\mathrm{SiO}_{2}$ activity in the latter, resulting in a decrease of driving force of the reactions given in Eqs. [41] through [44]. ${ }^{[333]}$

$$
\begin{gathered}
k_{m}=1.0 \times 10^{-5} \quad\left(\mathrm{~m} \mathrm{~s}^{-1}\right) \\
\left(\mathrm{SiO}_{2}\right)_{\text {slag }}=[\mathrm{Si}]+2[\mathrm{O}] \\
4[\mathrm{Al}]+3\left(\mathrm{SiO}_{2}\right)_{\text {slag }}=2\left(\mathrm{Al}_{2} \mathrm{O}_{3}\right)_{\text {slag }}+3[\mathrm{Si}] \\
4[\mathrm{Al}]+3\left(\mathrm{TiO}_{2}\right)_{\text {slag }}=2\left(\mathrm{Al}_{2} \mathrm{O}_{3}\right)_{\text {slag }}+3[\mathrm{Ti}] \\
{[\mathrm{Ti}]+\left(\mathrm{SiO}_{2}\right)_{\text {slag }}=\left(\mathrm{TiO}_{2}\right)_{\text {slag }}+[\mathrm{Si}]}
\end{gathered}
$$

Specifically, the decomposition of $\mathrm{SiO}_{2}$ into silicon and oxygen at the slag-steel interface, i.e., Eq. [41], increases the oxygen content in molten steel, resulting in the formation of $\mathrm{Al}_{2} \mathrm{O}_{3}$ inclusions in Al-killed steel. ${ }^{[330-334]} \mathrm{Ni}$ et al. ${ }^{[335,336]}$ recently developed a novel kinetic model to describe the dynamic slag-steel interfacial phenomena by adopting the slag-steel interfacial tension and interfacial oxygen content. The following steps were considered: (1) the $\mathrm{SiO}_{2}$ decomposition and $\mathrm{O}$ adsorption at the slag-steel interface, (2) the reaction between $\mathrm{Al}$ and $\mathrm{O}$, (3) the oxygen desorption at the interface, (4) the $\mathrm{Al}_{2} \mathrm{O}_{3}$ dissolution at the interface, (5) the effect of $\mathrm{Al}_{2} \mathrm{O}_{3}$ accumulation on $\mathrm{SiO}_{2}$ mass transfer, and (6) the mass transfer of the elements in steel and slag phases. The microscopic view of the illustration of the dynamic reaction mechanism at the steel-slag interface is shown in Figure 29. ${ }^{[336]}$

The interfacial kinetic model based on a dynamic interfacial tension variation developed by $\mathrm{Ni}$ et al. can be successfully applied to explain the reoxidation phenomena originating from $\mathrm{SiO}_{2}$-rich flux or use of rice husk ash as an insulation powder in a CC tundish, as reported by Kim et al..$^{[330,332]}$ and Feichtinger et al. ${ }^{331]}$ The macroscopic view of the schematic diagram for the reoxidation phenomena originating from the slag-metal interfacial reaction in tundish is shown in Figure 30. ${ }^{[330]}$ Because the reoxidation of molten steel generally provides the formation of alumina macroinclusions or clusters, which results in a clogging of SEN during the CC process, ${ }^{[39,330-332,337-340]}$ the control of the physicochemical properties of the ladle and tundish slag in view of viscosity, refractory corrosion, etc. ${ }^{[341-362]}$ as well as the simulation of related phenomena, should be further investigated to produce ultrahigh clean steels with less adverse operational problems.

\section{CONCLUSIONS}

The kinetic modeling for the nucleation, size growth, and compositional evolution of inclusions in steel was extensively reviewed in four sections. In Section II, the following topics were covered: Section II-A - the nucleation and initial growth of inclusion in molten steel during deoxidation; Sections II-B and II-C- the collision growth, motion, removal, and entrapment of inclusion in the molten steel in $\mathrm{CC}$ tundish and strand; and Section II-D - the prediction of inclusion composition in $\mathrm{CC}$ products. The modeling work tends to combine the nucleation theory, the population balance equation, the thermodynamic aspects for the precipitation or generation of inclusions in the steel varied with temperature, and the 3-D fluid flow in the metallurgical vessels. The purpose of the kinetic study is to predict the number density with the size, composition, and spatial distribution of inclusions in the molten steel or solid steel products. In Section III, the development of the thermodynamic model and relevant databases was reviewed. The systematic approach to the thermodynamic database for inclusion engineering was initiated by the IRSID, ArcelorMittal in the 1990s. They developed an in-house software, CEQCSI, for the calculation of slag-metal reactions be employing a cell model and GCA model. Recently, the FACT database, which is based on the associate model, modified quasi-chemical model, and compound energy formalism, was successfully used to calculate the phase equilibria of the multicomponent steel and slag in conjunction with various kinds of inclusions such as oxides, sulfides, and nitrides. In Section IV, the several kinetic models to estimate the compositional evolution of the inclusions were reviewed: Section IV-A - the CR model, Section IV-B - the reaction zone model, and Section IV-C - the TSR model. The flow dynamics in terms of stirring energy were needed to deduce the mass transfer coefficient of the elements in liquid steel. Not only by combining the slag phase mass transfer coefficient, which has generally been assumed to be $1 / 10$ of the metal phase mass transfer coefficient, but also by numerically solving the several nonlinear flux balance equations, the composition of inclusions can be predicted well by the CR model in a specific operation condition with some fitting parameters such as floatation, entrapment, agglomeration, and removal rate of inclusions. The (effective equilibrium) reaction zone model, which was initiated by Asai et al. to predict the slag-metal reaction characteristics, was extended to 
predict the inclusion composition using FACTSAGE macroprocessing functions. A determination of the volume (or equivalent mass) of metal and slag equilibrating in a short time period is critical to represent the actual processes and is strongly dependent on the mass transfer coefficient in metal and slag phases determined by different authors under different operating (or experimental) conditions. In Section V, the EERZ model was applied to predict the effect of reoxidation on the inclusion evolution in $\mathrm{CC}$ tundish. The harmful reoxidation products, i.e., alumina macroinclusions or clusters in Al-killed steel, can be formed by the interfacial reaction between molten steel and $\mathrm{SiO}_{2}$-rich slag. The interfacial kinetic model based on dynamic interfacial tension and oxygen adsorption/desorption at the slag-steel interface can be successfully applied to explain the reoxidation phenomena due to reactive slag.

\section{ACKNOWLEDGMENTS}

This work was partly supported by the Korea Evaluation Institute of Industrial Technology (KEIT, with Grant No. 20009956), funded by the Ministry of Trade, Industry \& Energy (MOTIE), Korea.

\section{REFERENCES}

1. L. Zhang, W. Pluschkell, and B.G. Thomas: 85th Steelmaking Conf. Proc., ISS, Warrendale, PA, 2002, pp. 463-76.

2. L. Zhang: Atlas of Non-Metallic Inclusions in Steels (I), Metallurgical Industry Press, Beijing, 2019.

3. L. Zhang: Atlas of Non-Metallic Inclusions in Steels (II), Metallurgical Industry Press, Beijing, 2019.

4. R. Kiessling: Proc. 2nd Int. Conf. on Clean Steel, Balatonfured, Hungary, The Metals Society, London, 1981, pp. 1-9.

5. L. Zhang and B.G. Thomas: Metall. Mater. Trans. B, 2006, vol. 37B, pp. 733-61.

6. L. Zhang: Steel Res. Int., 2006, vol. 77, pp. 258-69.

7. L. Zhang and B.G. Thomas: ISIJ Int., 2003, vol. 43, pp. 271-91.

8. J.H. Park and H. Todoroki: ISIJ Int., 2010, vol. 50, pp. 1333-46.

9. J.H. Park and Y. Kang: Steel Res. Int., 2017, vol. 88, art. no. 1700130.

10. R. Kiessling and N. Lange: Non-Metallic Inclusions in Steel: Part I: Inclusions Belongings to the Pseudo-Ternary System $\mathrm{MnO}$ $\mathrm{SiO}_{2}-\mathrm{Al}_{2} \mathrm{O}_{3}$ and Related Systems, The Metals Society, London, 1964.

11. R. Kiessling and N. Lange: Non-Metallic Inclusions in Steel: Part II: Inclusions Belongings to the Systems $\mathrm{MgO}-\mathrm{SiO}_{2}-\mathrm{Al}_{2} \mathrm{O}_{3}$, $\mathrm{CaO}-\mathrm{SiO}_{2}-\mathrm{Al}_{2} \mathrm{O}_{3}$ and Related Oxide Systems. Sulphide Inclusions, The Metals Society, London, 1966.

12. R. Kiessling: Non-Metallic Inclusions in Steel: Part III: The Origin and Bahavior of Inclusions and Their Influence on the Properties of Steels, The Metals Society, London, 1968.

13. R. Kiessling: Non-Metallic Inclusions in Steel: Part IV: Supplement to Parts I-III Including Literature Survey 1968-1976, The Metals Society, London, 1978.

14. R. Kiessling: Non-Metallic Inclusions in Steel: Part V, The Metals Society, London, 1989.

15. L. Zhang: Non-Metallic Inclusions in Steels: Fundamentals, Metallurgical Industry Press, Beijing, 2019 (in Chinese).

16. L. Zhang: Non-Metallic Inclusions in Steels: Industrial Practice, Metallurgical Industry Press, Beijing, 2019 (in Chinese).

17. S. Wang, L. Zhang, and J. Duan: Non-Metallic Inclusions and Element Segregation in Bearing Steels, Metallurgical Industry Press, Beijing, 2017 (in Chinese).

18. T.R. Allmand: J. Iron Steel Inst., 1958, vol. 190, pp. 359-72.
19. R.I.L. Guthrie: in On the Detection, Behavior and Control of Inclusions in Liquid Metals in Foundry Process - Their Chemistry and Physics, Katz and Landefeld, eds., Plenum Press, New York, NY, 1988, pp. 447-66.

20. E. Stampa and M. Cipparrone: Wire J. Int., 1987, vol. 20, pp. 4455.

21. Y. Nuri and K. Umezawa: Tetsu-to-Hagané, 1989, vol. 75, pp. $1897-1904$.

22. H.V. Atkinson and G. Shi: Progr. Mater. Sci., 2003, vol. 48, pp. 457-520

23. K. Okohira, N. Sato, and H. Mori: Trans. Iron Steel Inst. Jpn., 1974, vol. 14, pp. 103-09.

24. Y. Yoshida and Y. Funahashi: Trans. Iron Steel Inst. Jpn., 1976, vol. 16 , pp. $628-36$.

25. K.E. Burke: Metallography, 1975, vol. 8, pp. 473-88.

26. Y. Liu, L. Zhang, H. Duan, Y. Zhang, Y. Luo, and A.N. Conejo: Metall. Mater. Trans. A, 2016, vol. 47A, pp. 3015-25.

27. N. Aritomi and K. Gunji: Trans. Iron Steel Inst. Jpn., 1979, vol. 19 , pp. 152-61.

28. Z. Chen, J. Liu, and J. Zeng: Iron \& Steel (China), 1983, vol. 18, pp. $43-49$.

29. G.M. Weston and R.C. Andrew: ESR Steel Deoxidation and Slag Practice - Influence on Inclusion Morphology, 1984.

30. K. Oikawa, H. Ohtani, K. Ishida, and T. Nishizawa: ISIJ Int., 1995, vol. 35, pp. 402-08.

31. M. Imagumbai and H. Kajioka: ISIJ Int., 1996, vol. 36, pp. 1022-29.

32. M. Wang, Y. Bao, H. Cui, H. Wu, and W. Wu: ISIJ Int., 2010, vol. 50, pp. 1606-11.

33. S. He, G. Chen, Y. Guo, B. Shen, and Q. Wang: Metall. Mater. Trans. B, 2015, vol. 46B, pp. 585-94.

34. X. Zhang, L. Zhang, W. Yang, Y. Wang, Y. Liu, and Y. Dong: Metall. Mater. Trans. B, 2017, vol. 48B, pp. 701-12.

35. X. Zhang, L. Zhang, W. Yang, Y. Wang, Y. Ren, and Y. Dong: Metall. Res. Technol., 2017, vol. 114, art. no. 113.

36. J.H. Park, D.J. Kim, and D.J. Min: Metall. Mater. Trans. A, 2012, vol. 43A, pp. 2316-24.

37. H. Doostmohammadi, A. Karasev, and P.G. Jönsson: Steel Res. Int., 2010, vol. 81, pp. 398-406.

38. Y. Bi, A. Karasev, and P.G. Jönsson: Steel Res. Int., 2014, vol. 85 , pp. 659-69.

39. D. Janis, A. Karasev, R. Inoue, and P.G. Jönsson: Steel Res. Int., 2015, vol. 86, pp. 1271-78.

40. E.T. Turkdogan: J. Iron Steel Inst., 1966, vol. 204, pp. 914-19.

41. M.L. Turpin and J.F. Elliott: J. Iron Steel Inst., 1966, vol. 204, pp. $217-25$

42. T. Ohashi, H. Fujii, Y. Nuri, and K. Asano: Trans. Iron Steel Inst. Jpn., 1977, vol. 17, pp. 262-70.

43. K. Tsumuraya, M.S. Watanabe, and S.K. Ikeda: Trans. Iron Steel Inst. Jpn., 1988, vol. 28, pp. 869-75.

44. K. Wasai and K. Mukai: Metall. Mater. Trans. B, 1999, vol. 30B, pp. $1065-74$.

45. J.H. Shim, Y.J. Oh, and Y.W. Suh: Acta Mater., 2001, vol. 4, pp. 2115-22.

46. W. Khalifa, F.H. Samuel, and J.E. Gruzleski: Metall. Mater. Trans. A, 2004, vol. 35A, pp. 3233-50.

47. J. Zhang and H.G. Lee: ISIJ Int., 2004, vol. 44, pp. 1629-38.

48. H. Lei, K. Nakajima, and J.C. He: ISIJ Int., 2010, vol. 50, pp. $1735-45$.

49. G. Wang, Y. Xiao, C. Zhao, J. Li, and D. Shang: Metall. Mater. Trans. B, 2018, vol. 49B, pp. 282-90.

50. G.C. Wang, Q. Wang, S.L. Li, X.G. Ai, and D.P. Li: Acta Metall. Sinica, 2015, vol. 28, pp. 272-80.

51. N. Zong, Y. Liu, and P. He: RSC Adv., 2015, vol. 5, pp. 4838248390.

52. L. Zhang, S. Taniguchi, and K. Cai: Metall. Mater. Trans. B, 2000, vol. 31B, pp. 253-66.

53. L. Zhang and W. Pluschkell: Ironmak. Steelmak., 2003, vol. 30, pp. 106-10.

54. H. Duan, Y. Ren, B.G. Thomas, and L. Zhang: Metall. Mater. Trans. B, 2019, vol. 50B, pp. 36-41.

55. H. Duan, Y. Ren, and L. Zhang: Chem. Eng. Sci., 2019, vol. 196, pp. 14-24.

56. H. Yin, H. Shibata, T. Emi, and M. Suzuki: ISIJ Int., 1997, vol. 37 , pp. 936-45. 
57. P.G. Saffman and J.S. Turner: J. Fluid Mech., 1956, vol. 1, pp. $16-30$

58. U. Lindborg and K. Torssell: Trans. ASME, 1968, vol. 242, pp. 94-102.

59. S. Linder: Scand. J. Metall., 1974, vol. 3, pp. 137-50.

60. J. Abrahamson: Chem. Eng. Sci., 1975, vol. 30, pp. 1371-79.

61. J.J.E. Williams and R.I. Crane: Int. J. Multiphase Flow, 1983, vol. 9, pp. 421-35.

62. S. Taniguchi and A. Kikuchi: Tetsu-to-Hagané, 1992, vol. 78, pp. 527-35.

63. W. Fix, H. Jacobi, and K. Wünnenberg: Steel Res., 1993, vol. 64, pp. 71-76.

64. A.S. Koziol and H.G. Leighton: J. Atmos. Sci., 1996, vol. 53, pp. 1910-20.

65. F.E. Kruis and K.A. Kusters: J. Aerosol Sci., 1996, vol. 27, pp. S263-64.

66. K.C. Hu and R. Mei: 7th Int. Symp. on Gas-Solid Flows - ASME Fluids Engineering Conf., Vancouver, BC, Canada, 1997, paper no. FEDSM97-3608.

67. F.E. Kruis and K.A. Kusters: Chem. Eng. Commun., 1997, vol. 158, pp. 201-30.

68. L.P. Wang, A.S. Wexler, and Y. Zhou: Phys. Fluids, 1998, vol. 10, pp. 266-76.

69. R. Mei and K.C. Hu: J. Fluid Mech., 1999, vol. 391, pp. 67-89.

70. Z. Dodin and T. Elperin: Phys. Fluids, 2002, vol. 14, pp. 2921-24.

71. H. Suito and R. Inoue: ISIJ Int., 1996, vol. 36, pp. 528-36.

72. H. Itoh, M. Hino, and S. Ban-ya: Metall. Mater. Trans. B, 1997, vol. 28B, pp. $953-56$

73. S. Kobayashi: ISIJ Int., 1999, vol. 39, pp. 664-70.

74. L. Holappa, M. Hamalainen, M. Liukkonen, and M. Lind: Ironmak. Steelmak., 2003, vol. 30, pp. 111-15.

75. W. Cha, D. Kim, Y. Lee, and J. Pak: ISIJ Int., 2004, vol. 44, pp. 1134-39.

76. J.H. Park and D.S. Kim: Metall. Mater. Trans. B, 2005, vol. 36B, pp. 495-502.

77. J.H. Park and Y.B. Kang: Metall. Mater. Trans. B, 2006, vol. 37B, pp. 791-98.

78. J.H. Park: Metall. Mater. Trans. B, 2007, vol. 38B, pp. 657-63.

79. S.K. Choudhary and A. Ghosh: ISIJ Int., 2008, vol. 48, pp. 1552 59.

80. J.H. Park, S.B. Lee, and H.R. Gaye: Metall. Mater. Trans. B, 2008, vol. 39B, pp. 853-61.

81. J.H. Park: Mater. Sci. Eng. A, 2008, vol. 472, pp. 43-51.

82. W.V. Bielefeldt and A.C.F. Vilela: Steel Res. Int., 2010, vol. 81, pp. 1064-69.

83. J.H. Park: Calphad, 2011, vol. 35, pp. 455-62.

84. Y. Ren, L. Zhang, W. Yang, and H. Duan: Metall. Mater. Trans. $B, 2014$, vol. 45B, pp. 2057-71.

85. J.S. Park and J.H. Park: Metall. Mater. Trans. B, 2014, vol. 45B, pp. 953-60.

86. S.K. Kwon, Y.M. Kong, and J.H. Park: Met. Mater. Int., 2014, vol. 20, pp. 959-66.

87. W.V. Bielefeldt and A.C.F. Vilela: Steel Res. Int., 2015, vol. 86, pp. $375-85$.

88. S.K. Kwon, J.S. Park, and J.H. Park: ISIJ Int., 2015, vol. 55, pp. $2589-96$

89. Y. Guo, S. He, G. Chen, and Q. Wang: Metall. Mater. Trans. B, 2016, vol. 47B, pp. 2549-57.

90. J.S. Park and J.H. Park: Metall. Mater. Trans. B, 2016, vol. 47B, pp. $3225-30$.

91. Y. Ren and L. Zhang: ISIJ Int., 2017, vol. 57, pp. 68-75.

92. J.H. Shin and J.H. Park: ISIJ Int., 2018, vol. 58, pp. 88-97.

93. J.H. Shin and J.H. Park: Metall. Mater. Trans. B, 2018, vol. 49B, pp. 311-24.

94. J.H. Shin and J.H. Park: J. Iron Steel Res. Int., 2018, vol. 25, pp. $157-63$.

95. J. Wang, W. Li, Y. Ren, and L. Zhang: Steel Res. Int., 2019, vol. 90 , art. no. 201800600.

96. C. Shi and J.H. Park: Metall. Mater. Trans. B, 2019, vol. 50B, pp. 1139-47.

97. Y. Zhang, Y. Ren, and L. Zhang: Metall. Res. Technol., 2017, vol. 114 , art. no. 308 .

98. F. Huang, L. Zhang, Y. Zhang, and Y. Ren: Metall. Mater. Trans. B, 2017, vol. 48B, pp. 2195-2206.
99. Y. Ren, L. Zhang, H. Ling, Y. Wang, D. Pan, Q. Ren, and X. Wang: Metall. Mater. Trans. B, 2017, vol. 48B, pp. 1433-38.

100. Y. Ren and L. Zhang: Ironmak. Steelmak., 2018, vol. 45, pp. 585 91.

101. W. Yamada, T. Matsumiya, and A. Ito: Proc. 6th Int. Iron Steel Congr., ISIJ, Tokyo, 1990, pp. 618-25.

102. C. Liu, M. Yagi, X. Gao, S. Kim, F. Huang, S. Ueda, and S. Kitamura: Metall. Mater. Trans. B, 2018, vol. 49B, pp. 113-22.

103. V.A. Kravchenko, V.M. Kirsanov, M.I. Staroseletskij, N.G. Miroshnichenko, A.G. Petrichenko, I.G. Uzlov, and L.A. Moiseeva: Metallurgicheskaya i Gornorudnaya Promyshlennost' (Russia), 2000, vol. 1, pp. 26-30.

104. S.K. Choudhary and A. Ghosh: ISIJ Int., 2009, vol. 49, pp. 181927.

105. H. Shibata, T. Tanaka, K. Kimura, and S. Kitamura: Ironmak. Steelmak., 2010, vol. 37, pp. 522-28.

106. H. Shibata, K. Kimura, T. Tanaka, and S. Kitamura: ISIJ Int., 2011, vol. 51, pp. 1944-50.

107. A. Harada, N. Maruoka, H. Shibata, and S. Kitamula: ISIJ Int., 2013, vol. 53, pp. 2110-17.

108. A. Harada, N. Maruoka, H. Shibata, and S. Kitamula: ISIJ Int., 2013, vol. 53, pp. 2118-25.

109. A. Harada, N. Maruoka, H. Shibata, M. Zeze, N. Asahara, F. Huang, and S. Kitamula: ISIJ Int., 2014, vol. 54, pp. 2569-77.

110. J.Y. Choi, S.K. Kim, Y.B. Kang, and H.G. Lee: Steel Res. Int., 2015, vol. 86, pp. 284-92.

111. J.H. Shin and J.H. Park: Metall. Mater. Trans. B, 2020, vol. 51B, pp. 1211-24.

112. J.H. Shin and J.H. Park: Metall. Mater. Trans. B, 2017, vol. 48B, pp. 2820-25.

113. J.H. Shin, Y. Chung, and J.H. Park: Metall. Mater. Trans. B, 2017, vol. 48B, pp. 46-59.

114. L. Zhang and S. Taniguchi: Int. Mater. Rev., 2000, vol. 45, pp. 59-82.

115. L. Zhang, J. Aoki, and B.G. Thomas: Metall. Mater. Trans. B, 2006, vol. 37B, pp. 361-79.

116. H. Duan, Y. Ren, and L. Zhang: Metall. Mater. Trans. B, 2019, vol. 50B, pp. 16-21.

117. H. Duan, Y. Ren, and L. Zhang: Steel Res. Int., 2019, vol. 90, art. no. 1800576.

118. H. Duan, P.R. Scheller, Y. Ren, and L. Zhang: JOM, 2019, vol. 71, pp. 69-77.

119. W. Pan, K. Uemura, and S. Koyama: Tetsu-to-Hagané, 1992, vol. 78, pp. 87-94.

120. S. Yokoya, S. Takagi, H. Souma, M. Iguchi, Y. Asako, and S. Hara: ISIJ Int., 1998, vol. 38, pp. 1086-92.

121. Y. Miki: Kawasaki Steel Techn. Rep., 2001.

122. L. Zhang and S. Taniguchi: Ironmak. Steelmak., 2002, vol. 29, pp. 326-36.

123. J. Kumar, N.N. Tripathi, and S. Du: Steel Grips, 2003, vol. 1, pp. 133-39.

124. Y. Kwon, J. Zhang, and H.G. Lee: ISIJ Int., 2006, vol. 46, pp. $257-66$.

125. L. Zhang, Q. Ren, H. Duan, Y. Ren, W. Chen, G. Cheng, W. Yang, and S. Sridhar: Min. Process. Extr. Metall., 2020, vol. 129, pp. 184-206.

126. K. Shirabe and J. Szekely: Trans. Iron Steel Inst. Jpn., 1983, vol. 23 , pp. $465-74$.

127. O.J. Ilegbusi and J. Szekely: in Mathematical Modeling of Materials Processing Operations, J. Szekely et al., eds., TMS, Warrendale, PA, 1987, pp. 409-29.

128. Q. Wang, S. Li, Y. Li, L. Zhang, and X. Wang: Proc. EPD Congr., TMS 2013: Annual Meeting \& Exhibition, 2013, pp. $135-42$.

129. Y. Li, L. Zhang, and Y. Ren: Proc. EPD Symp. on Pyrometallurgy in Honor of David G.C. Robertson, TMS 2014: Annual Meeting \& Exhibition, 2014, pp. 659-66.

130. H. Duan, Y. Ren, and L. Zhang: Metall. Mater. Trans. B, 2019, vol. 50B, pp. $1476-89$

131. M. Sano and K. Mori: Trans. Iron Steel Inst. Jpn., 1983, vol. 23, pp. 169-75.

132. M. Mabuchi: Tetsu-to-Hagané, 1986, vol. 72, p. S1074.

133. T. Robertson, P. Moore, and J.F. Hawkins: Ironmak. Steelmak., 1986, vol. 13, pp. 195-203. 
134. S.K. Choudhary and D. Mazumdar: Steel Res. Int., 1995, vol. 66, pp. 199-205.

135. Q. Yuan, B.G. Thomas, and S.P. Vanka: Metall. Mater. Trans. $B, 2004$, vol. 35B, pp. 685-702.

136. Y. He and Y. Sahai: Metall. Trans. B, 1987, vol. 18B, pp. 81-92.

137. A. Aguilar-Corona, R.D. Morales, M. Diaz-Cruz, J. Palafox-Ramos, and H. Rodriguez-Hernandez: Steel Res. Int., 2002, vol. 73, pp. 438-44.

138. P.K. Jha and S.K. Dash: ISIJ Int., 2002, vol. 42, pp. 670-72.

139. H.J. Odenthal, R. Bolling, and H. Pfeifer: Steel Res. Int., 2003, vol. 74, pp. 44-55.

140. Q. Yuan, B.G. Thomas, and S.P. Vanka: Metall. Mater. Trans. $B$, 2004, vol. 35B, pp. 703-14.

141. C. Pfeiler, B.G. Thomas, M. Wu, A. Ludwig, and A. Kharicha: Steel Res. Int., 2008, vol. 79, pp. 599-607.

142. W. Chen, Y. Ren, and L. Zhang: JOM, 2018, vol. 70, pp. 2968 79 .

143. L. Zhang and Y. Wang: JOM, 2012, vol. 64, pp. 1063-74.

144. Q. Ren, Y. Zhang, L. Zhang, J. Wang, Y. Chu, Y. Wang, and Y. Ren: J. Mater. Res. Technol., 2020, vol. 9, pp. 5648-65.

145. I. Takahashi, T. Sakae, and T. Yoshida: Tetsu-to-Hagané, 1967, vol. 53 , pp. $350-52$.

146. Y. Ren, C. Pistorius, and L. Zhang: Metall. Mater. Trans. B, 2017, vol. 48B, pp. 2281-92.

147. W. Yang, C. Guo, C. Li, and L. Zhang: Metall. Mater. Trans. B, 2017, vol. 48B, pp. 2267-73.

148. G. Cheng, W. Li, X. Zhang, and L. Zhang: Metals, 2019, vol. 9, art. no. 642

149. Y. Chu, W. Li, Y. Ren, and L. Zhang: Metall. Mater. Trans. B, 2019, vol. 50B, pp. 2047-62.

150. M. Li, H. Matsuura, and F. Tsukihashi: Metall. Mater. Trans. B, 2017, vol. 48B, pp. 1-9.

151. Q. Wang, X. Zou, H. Matsuura, and C. Wang: Metall. Mater. Trans. B, 2018, vol. 49B, pp. 18-22.

152. T.J. Baker and J.A. Charles: Effect of Second-Phase Particles on the Mechanical Properties of Steel, The Iron and Steel Institute, Scarborough, 1971, pp. 88-94.

153. A.D. Wilson: Metallography, 1979, vol. 12, pp. 233-55.

154. S. Kimura, I. Hoshikawa, N. Ibaraki, S. Hattori, and T. Choda: Tetsu-to-Hagané, 2002, vol. 88, pp. 755-62.

155. W. Yang, C. Guo, L. Zhang, H. Ling, and C. Li: Metall. Mater. Trans. B, 2017, vol. 48B, pp. 2717-30.

156. L. Zhang, C. Guo, W. Yang, Y. Ren, and H. Ling: Metall. Mater. Trans. B, 2018, vol. 49B, pp. 803-11.

157. Q. Ren, W. Yang, L. Cheng, L. Zhang, and A.N. Conejo: Metall. Mater. Trans. B, 2020, vol. 51B, pp. 200-12.

158. D.C. Hilty and V.T. Popp: Electric Furnace Conf. Proc., 1969, pp. $52-66$.

159. T. Ototani: Calcium Clean Steel, Springer, New York, 1986.

160. K. Larsen and R.J. Fruehan: Iron Steelmaker (ISS Trans.), 1991, vol. 12 , pp. $125-32$.

161. E. Wong and S. Ritza: Iron Steelmaker (ISS Trans.), 1999, vol. 26, pp. 23-27.

162. J.M.A. Geldenhuis and P.C. Pistorius: Ironmak. Steelmak., 2000, vol. 27, pp. 442-49.

163. J.H. Park, D.S. Kim, and S.B. Lee: Metall. Mater. Trans. B, 2005, vol. 36B, pp. 67-73.

164. N. Verma, P.C. Pistorius, R.J. Fruehan, M. Potter, M. Lind, and S. Story: Metall. Mater. Trans. B, 2011, vol. 42B, pp. 720-29.

165. N. Verma, P.C. Pistorius, R.J. Fruehan, M. Potter, M. Lind, and S. Story: Metall. Mater. Trans. B, 2011, vol. 42B, pp. 711-19.

166. W. Yang, L. Zhang, X. Wang, Y. Ren, X. Liu, and Q. Shan: ISIJ Int., 2013, vol. 53, pp. 1401-10.

167. Y. Ren, L. Zhang, and S. Li: ISIJ Int., 2014, vol. 54, pp. 2772-79.

168. G. Yang and X. Wang: ISIJ Int., 2015, vol. 55, pp. 126-33.

169. D. Zhao, H. Li, C. Bao, and J. Yang: ISIJ Int., 2015, vol. 55, pp. 2115-24.

170. Y. Liu and L. Zhang: Metall. Mater. Trans. B, 2018, vol. 49B, pp. 1624-31

171. Y. Liu, L. Zhang, Y. Zhang, H. Duan, Y. Ren, and W. Yang: Metall. Mater. Trans. B, 2018, vol. 49B, pp. 610-26.

172. L. Zhang, Y. Liu, Y. Zhang, W. Yang, and W. Chen: Metall. Mater. Trans. B, 2018, vol. 49B, pp. 1841-59.

173. M. Li, Y. Liu, and L. Zhang: Metall. Res. Technol., 2019, vol. 116 , art. no. 206
174. D. Brooksbank and K.W. Andrews: J. Iron Steel Inst., 1972, vol. 210, pp. 246-55.

175. M.D. Modzhuk, M.B. Roshchin, and N.N. Potapov: Weld. Prod. (English Translation of Svarochnoe Proizvodstvo), 1986, vol. 33, pp. $41-43$.

176. S.K. Dhua, A. Ray, S.K. Sen, M.S. Prasad, K.B. Mishra, and S. Jha: J. Mater. Eng. Perform., 2000, vol. 9, pp. 700-09.

177. D. Zhou, J. Fu, X. Chen, and J. Li: J. Univ. Sci. Technol. Beijing. Mineral Metall. Mater. (English Ed.), 2001, vol. 8, pp. 25-27.

178. A. Sawahata, H. Tanigawa, and M. Enomoto: J. Jpn. Inst. Met., 2008, vol. 72, pp. 176-80.

179. S. Liu, Q. Huang, C. Li, and B. Huang: Fus. Eng. Des., 2009, vol. 84, pp. 1214-18

180. N. Choi, K.R. Lim, Y.S. Na, U. Glatzel, and J.H. Park: J. Alloys Compd., 2018, vol. 763, pp. 546-57.

181. M.H. Lee and J.H. Park: Metall. Mater. Trans. B, 2018, vol. 49B, pp. 877-93.

182. Q. Ren, L. Zhang, and W. Yang: Steel Res. Int., 2018, vol. 89, art. no. 201800047

183. M.H. Lee, R. Kim, and J.H. Park: Sci. Rep., 2019, vol. 9, art. no. 6369.

184. D.E. Jodi, N. Park, and J.H. Park: Mater. Charact., 2019, vol. 157 , art. no. 109888 .

185. D.E. Jodi, J.H. Park, and N. Park: Mater. Lett., 2020, vol. 258, art. no. 126772.

186. D.E. Jodi, J.H. Park, B. Straumal, and N. Park: Mater. Lett., 2020, vol. 258, art. no. 126806.

187. D.E. Jodi, N. Choi, J.H. Park, and N. Park: Metall. Mater. Trans. A, 2020, vol. 51A, pp. 3228-37.

188. L. Xu, J. Yang, J.H. Park, and H. Ono: Metals, 2020, vol. 10, art. no. 162.

189. L. Holappa and A.S. Helle: J. Mater. Process. Technol., 1995, vol. 53, pp. 177-86.

190. Y. Furuya, H. Hirukawa, T. Kimura, and M. Hayaishi: Metall. Mater. Trans. A, 2007, vol. 38A, pp. 1722-30.

191. Y. Murakami and M. Endo: Int. J. Fatigue, 1994, vol. 16, pp. $163-82$

192. S.H. Jeon, S.T. Kim, I.S. Lee, J.H. Park, K.T. Kim, J.S. Kim, and Y.S. Park: Mater. Trans., 2011, vol. 52, pp. 416-22.

193. S.H. Jeon, S.T. Kim, I.S. Lee, J.H. Park, K.T. Kim, and Y.S. Park: Corros. Sci., 2011, vol. 53, pp. 1408-16.

194. H.K.D.H. Bhadeshia: Progr. Mater. Sci., 2012, vol. 57, pp. 268 435.

195. J.S. Park, C. Lee, and J.H. Park: Metall. Mater. Trans. B, 2012, vol. 43B, pp. 1550-64.

196. D.S. Sarma, A. Karasev, and P.G. Jönsson: ISIJ Int., 2009, vol. 49, pp. 1063-74.

197. G. Wrannglen: Corr. Sci., 1969, vol. 9, pp. 585-602.

198. S.S. Babu, S.A. David, J.M. Vitek, K. Mundra, and T. Debroy: Mater. Sci. Technol., 1995, vol. 11, pp. 186-99.

199. S.X. Li: Int. Mater. Rev., 2012, vol. 57, pp. 92-114.

200. H.B. Xue and Y.F. Cheng: Corr. Sci., 2012, vol. 53, pp. 12011208.

201. Y. Kang, J. Jang, J.H. Park, and C. Lee: Met. Mater. Int., 2014, vol. 20, pp. 119-27.

202. D. Kim, K. Han, B. Lee, J.H. Park, and C. Lee: Metall. Mater. Trans. A, 2014, vol. 45A, pp. 2046-54.

203. Y. Kang, K. Han, J.H. Park, and C. Lee: Metall. Mater. Trans. A, 2014, vol. 45A, pp. 4753-57.

204. Y. Kang, K. Han, J.H. Park, and C. Lee: Metall. Mater. Trans. A, 2015, vol. 46A, pp. 3581-91.

205. M. Enomoto: Met. Mater. Int., 1998, vol. 4, pp. 115-23.

206. K. Wasai and K. Mukai: ISIJ Int., 2002, vol. 42, pp. 467-73.

207. T. Nakaoka, S. Taniguchi, K. Matsumoto, and S.T. Johansen: ISIJ Int., 2001, vol. 41, pp. 1103-11.

208. H. Ling, F. Li, L. Zhang, and A.N. Conejo: Metall. Mater. Trans. B, 2016, vol. 47B, pp. 1950-61.

209. Y. Jin, Z. Liu, and R. Takata: ISIJ Int., 2010, vol. 50, pp. 371-79.

210. O.J. Illegbusi and J. Szekely: ISIJ Int., 1989, vol. 29, pp. 1031-39.

211. A.K. Sinha and Y. Sahai: ISIJ Int., 1993, vol. 33, pp. 556-66.

212. H. Tozawa, Y. Kato, K. Sorimachi, and T. Nakanishi: ISIJ Int., 1999, vol. 39, pp. 426-34.

213. Y. Miki and B.G. Thomas: Metall. Mater. Trans. B, 1999, vol. 30B, pp. 639-54. 
214. Y. Miki, B.G. Thomas, A. Denissov, and Y. Shimada: Iron Steelmaker, 1997, vol. 24, pp. 31-38.

215. H. Ling, L. Zhang, and H. Li: Metall. Mater. Trans. B, 2016, vol. 47B, pp. 2991-3012.

216. K. Nogi and K. Ogino: Can. Metall. Q., 1983, vol. 22, pp. 19-28.

217. A.W. Cramb and I. Jimbo: Iron Steelmaker (ISS Trans.), 1990, vol. 11, pp. 67-79.

218. A.W. Cramb and I. Jimbo: Steel Res., 1989, vol. 60, pp. 157-65.

219. N. Zouvelou, X. Mantzouris, and P. Nikolopoulos: J. Adhes. Adhes., 2007, vol. 27, pp. 380-86.

220. T. Yoshioka, K. Nakahata, T. Kawamura, and Y. Ohba: ISIJ Int., 2016, vol. 56, pp. 1973-81.

221. M. Yao, M. Ichimiya, M. Tamiya, K. Suzuki, K. Sugiyama, and R. Mesaki: Trans. Iron Steel Inst. Jpn., 1984, vol. 24, pp. 211-15.

222. M. Yao, M. Ichimiya, S. Kiyohara, K. Suzuki, K. Sugiyama, and R. Mesaki: 68th Steelmaking Conf. Proc., ISS-AIME, Warrendale, PA, 1985, pp. 27-33.

223. L.J. Heaslip, I.D. Sommerville, A. McLean, L. Swartz, and W.G. Wilson: Iron Steelmaker, 1987, vol. 14, pp. 49-64.

224. K. Takatani, K. Nakai, N. Kasai, T. Watanabe, and H. Nakajima: ISIJ Int., 1989, vol. 29, pp. 1063-68.

225. N. Bessho, R. Yoda, and H. Yamasaki: Proc. 6th Int. Iron and Steel Congr., ISIJ, Tokyo, 1990, pp. 340-47.

226. I. Sawada, H. Tanaka, and I. Takigawa: Proc. 6th Int. Iron and Steel Congr., ISIJ, Tokyo, 1990, pp. 334-39.

227. K. Takantani, K. Nakai, N. Kasai, T. Watanabe, and H. Nakajima: Proc. 6th Int. Iron and Steel Congr., ISIJ, Tokyo, 1990, pp. 430-37.

228. H. Tozawa, H. Kitaoka, K. Sorimachi, H. Ishizuka, and M Ohnishi: Proc. 6th Int. Iron and Steel Congr., ISIJ, Tokyo, 1990, pp. 438-45.

229. N. Bessho, R. Yoda, H. Yamasaki, T. Fujii, T. Nozaki, and S. Takatori: Iron Steelmaker, 1991, vol. 18, pp. 39-44.

230. D. Gupta, S. Subramaniam, and A.K. Lahiri: Steel Res., 1991, vol. 62 , pp. 496-500.

231. B.G. Thomas and F.M. Najjar: Appl. Math. Model., 1991, vol. 15 , pp. $226-43$

232. A. Imamura, A. Kusano, and N. Moritama: Tetsu-to-Hagané, 1992, vol. 78, pp. 101-106.

233. A. Idogawa, M. Sugizawa, S. Takeuchi, K. Sorimachi, and T. Fujii: Mater. Sci. Eng. A, 1993, vol. 173, pp. 293-97.

234. I. Sawada, Y. Kishida, K. Okazawa, and H. Tanaka: Tetsu-to-Hagané, 1993, vol. 79, pp. 160-66.

235. T. Teshima, J. Kubota, M. Suzuki, K. Ozawa, T. Masaoka, and S. Miyahara: Tetsu-to-Hagané, 1993, vol. 79, pp. 576-82.

236. S. Yokoya, Y. Asako, S. Hara, and J. Szekely: ISIJ Int., 1994, vol. 34 , pp. 883-88.

237. S. Yokoya, R. Westoff, Y. Asako, S. Hara, and J. Szekely: ISIJ Int., 1994, vol. 34, pp. 889-95.

238. M.R. Aboutalebi, M. Hasan, and R.I.L. Guthrie: Metall. Mater Trans. B, 1995, vol. 26B, pp. 731-44.

239. P. Gardin, J. Galpin, M. Regnier, and J. Radot: IEEE Trans. Magn., 1995, vol. 31, pp. 2088-91.

240. Y. Ho and W. Hwang: ISIJ Int., 1996, vol. 36, pp. 1030-35.

241. T. Ishii, S.S. Sazhin, and M. Makhlouf: Ironmak. Steelmak., 1996, vol. 23, pp. 267-72.

242. R. McDavid and B.G. Thomas: Metall. Mater. Trans. B, 1996 vol. 27B, pp. 672-85.

243. D. Gupta, S. Chakraborty, and A.K. Lahiri: ISIJ Int., 1997, vol. 37 , pp. $654-58$

244. X.K. Lan, J.M. Khodadadi, and F. Shen: Metall. Mater. Trans. B, 1997, vol. 28B, pp. 321-32.

245. X. Huang and B.G. Thomas: Can. Metall. Q., 1998, vol. 37, pp. 197-212.

246. D. Xu, W.K. Jones, and J.W. Evans: Proc. Metals and Advanced Materials: Modeling, Deisgn and Properties, TMS, Warrendale, PA, 1998, pp. 3-14.

247. H. Yang, L. Zhao, X. Zhang, K. Deng, W. Li, and Y. Gan: Metall. Mater. Trans. B, 1998, vol. 29B, pp. 1345-56.

248. S. Yokoya, S. Takagi, M. Iguchi, Y. Asako, R. Bestoff, and S. Hara: ISIJ Int., 1998, vol. 38, pp. 827-33.

249. J. Anagnostopoulos and G. Bergeles: Metall. Mater. Trans. B, 1999, vol. 30B, pp. 1095-1105.

250. M. Hanao, M. Kawamoto, H. Mizukami, and K. Hanazaki: Steelmaking Conf. Proc., ISS, Warrendale, PA, 1999, pp. 63-70.
251. L.J. Heaslip and J. Schade: Iron Steelmaker, 1999, vol. 26, pp. 33-41.

252. C. Fan and W. Hwang: ISIJ Int., 2000, vol. 40, pp. 1105-14.

253. D.S. Kim, W.S. Kim, and K.H. Cho: ISIJ Int., 2000, vol. 40, pp. $670-76$

254. B. Li, T. Okane, and T. Umeda: Metall. Mater. Trans. B, 2000, vol. 31B, pp. 1491-1503.

255. H. Mizukami, M. Hanao, S. Hiraki, M. Kawamoto, T. Watanabe, A. Hayashi, and M. Iguchi: Tetsu-to-Hagané, 2000, vol. 86, pp. $265-70$

256. R.D. Morales, J. Barreto, S. Lopez-Ramirez, J. Palafox-Ramos, and M. Diaz-Cruz: Model. Simul. Mater. Sci. Eng., 2000, vol. 8, pp. $781-801$.

257. S. Yokoya, S. Takagi, M. Iguchi, K. Marukawa, and S. Hara: ISIJ Int., 2000, vol. 40, pp. 578-83.

258. H. Bai and B.G. Thomas: Metall. Mater. Trans. B, 2001, vol. 32B, pp. 702-22.

259. K. Takatani and Y. Tanizawa: ISIJ Int., 2001, vol. 41, pp. 1252 61.

260. B.G. Thomas and L. Zhang: ISIJ Int., 2001, vol. 41, pp. 1181-93.

261. S. Yokoya, S. Takagi, M. Iguchi, K. Marukawa, and S. Hara: ISIJ Int., 2001, vol. 41, pp. S47-S51.

262. Y. Miki and S. Takeuchi: ISIJ Int., 2003, vol. 43, pp. 1548-55.

263. R. Sanchez-Perez, R.D. Morales, M. Diaz-Cruz, O. Olivares-Xometl, and J. Palafox-Ramos: ISIJ Int., 2003, vol. 43, pp. 637-46.

264. Q. Yuan, B. Zhao, S.P. Vanka, and B.G. Thomas: Steel Res. Int., 2005, vol. 76, pp. 33-43.

265. K. Jin, B.G. Thomas, and X. Ruan: Metall. Mater. Trans. B, 2016, vol. 47B, pp. 548-65.

266. M. Javurek, P. Gittler, R. Rössler, B. Kaufmann, and H. Prelinger: Steel Res. Int., 2005, vol. 76, pp. 64-70.

267. G.F. Bolling and J.A. Cisse: J. Cryst. Growth, 1971, vol. 10, pp. $55-66$.

268. M. Yemmou, M.A.A. Azouni, and P. Casses: J. Cryst. Growth, 1993, vol. 128, pp. 1130-36

269. K. Mukai and W. Lin: Tetsu-to-Hagané, 1994, vol. 80, pp. 533 38.

270. Z. Wang, K. Mukai, and I.J. Lee: ISIJ Int., 1999, vol. 39, pp. 553-62.

271. G. Kaptay and K.K. Kelemen: ISIJ Int., 2001, vol. 41, pp. 305 07.

272. G. Kaptay: Metall. Mater. Trans. A, 2002, vol. 33A, pp. 1869-73.

273. M. Imagumbai: ISIJ Int., 1994, vol. 34, pp. 896-905.

274. M. Wintz, M. Bobadilla, and H. Gaye: ISIJ Int., 1995, vol. 35, pp. $715-26$

275. M. Suzuki, R. Yamaguchi, K. Murakami, and M. Nakada: ISIJ Int., 2001, vol. 41, pp. 247-56.

276. Z. Liu, J. Wei, and K. Cai: ISIJ Int., 2002, vol. 42, pp. 958-63.

277. D. Shangguan, S. Ahuja, and D.M. Stefanescu: Metall. Mater. Trans. A, 1992, vol. 23A, pp. 669-80.

278. D. Shangguan and D.M. Stefanescu: Metall. Mater. Trans. B, 1991, vol. 22B, pp. 385-89.

279. D.M. Stefanescu and A.V. Catalina: ISIJ Int., 1998, vol. 38, pp. 503-05.

280. D.M. Stefanescu, F.R. Juretzko, B.K. Dhindaw, A. Catalina, S. Sen, and P.A. Curreri: Metall. Mater. Trans. A, 1998, vol. 29A, pp. $1697-1706$.

281. M. Yamazaki, Y. Natsume, H. Harada, and K. Ohsasa: ISIJ Int., 2006, vol. 46, pp. 903-908.

282. S.M. Lee, S.J. Kim, Y.B. Kang, and H.G. Lee: ISIJ Int., 2012 , vol. 52 , pp. $1730-39$.

283. W. Chen, L. Zhang, Q. Wang, X. Cai, and X. Zhang: Metall. Mater. Trans. B, 2020, vol. 51B, pp. 0000-00.

284. C. Gatellier, H. Gaye, J. Lehmann, J.N. Pontoire, and P.V. Riboud: Steel Res., 1993, vol. 64, pp. 87-92.

285. H. Gaye, J. Lehmann, P. Rocabois, and F. Ruby-Meyer: Steel Res., 2001, vol. 72, pp. 446-51.

286. H. Gaye, J. Lehmann, P. Rocabois, and F. Ruby-Meyer: High Temp. Mater. Process., 2001, vol. 20, pp. 285-92.

287. J. Lehmann: Rev. Metall. Paris, 2008, vol. 105, pp. 539-50.

288. I.H. Jung, S.A. Decterov, and A.D. Pelton: ISIJ Int., 2004, vol. 44, pp. 527-36.

289. Y.B. Kang, H.S. Kim, J. Zhang, and H.G. Lee: J. Phys. Chem. Solids, 2005, vol. 66, pp. 219-25. 
290. S.A. Decterov, Y.B. Kang, and I.H. Jung: J. Phase Equilib. Diffus., 2009, vol. 30, pp. 443-61.

291. I.H. Jung, Y.B. Kang, S.A. Decterov, and A.D. Pelton: Metall. Mater. Trans. B, 2004, vol. 35B, pp. 259-68.

292. Y.B. Kang and H.G. Lee: ISIJ Int., 2004, vol. 44, pp. 1006-15.

293. I.H. Jung, G. Eriksson, P. Wu, and A.D. Pelton: ISIJ Int., 2009, vol. 49, pp. 1290-97.

294. E. Roos, A. Karasev, and P.G. Jönsson: Steel Res. Int., 2014, vol. 85 , pp. $1410-17$.

295. V. Thapliyal, A. Kumar, D. Robertson, and J. Smith: ISIJ Int., 2015, vol. 55, pp. 190-99.

296. I.H. Jung: Calphad, 2010, vol. 34, pp. 332-62.

297. D.G.C. Robertson, S. Ohguchi, B. Deo, and A. Willis: Ironmak. Steelmak., 1984, vol. 11, pp. 262-73.

298. G. Okuyama, K. Yamaguchi, S. Takeuchi, and K. Sorimachi: ISIJ Int., 2000, vol. 40, pp. 121-28.

299. K.J. Graham and G.A. Irons: Iron Steel Technol., 2009, vol. 6, pp. 164-73.

300. K.J. Graham and G.A. Irons: Proc. Int. Symp. on Highly Innovative Novel Operations "Future Steelmaking Metallurgy," Iron and Steel Institute of Japan, Tokyo, 2010, pp. 65-74.

301. A. Galindo, G.A. Irons, S. Sun, and K.S. Coley: Proc. Challenges and Transformative Solutions to Sustainable Steelmaking and Casting for Environment-Friendly Metallurgical Innovation, Iron and Steel Institute of Japan, Tokyo, 2015, pp. 22-31.

302. Y. Tabatabaei, K.S. Coley, G.A. Irons, and S. Sun: Metall. Mater. Trans. B, 2018, vol. 49B, pp. 375-87.

303. Y. Tabatabaei, K.S. Coley, G.A. Irons, and S. Sun: Metall. Mater. Trans. B, 2018, vol. 49B, pp. 2022-37.

304. Y. Tabatabaei, K.S. Coley, G.A. Irons, and S. Sun: Metall. Mater. Trans. B, 2018, vol. 49B, pp. 2744-56.

305. D. Lu, G.A. Irons, and W. Lu: Ironmak. Steelmak., 1994, vol. 21, pp. $362-72$.

306. A. Harada, A. Matsui, S. Nabeshima, N. Kikuchi, and Y. Miki: ISIJ Int., 2017, vol. 57, pp. 1546-52.

307. D.J. Sosinsky and I.D. Sommerville: Metall. Trans. B, 1986, vol. 17B, pp. 331-37.

308. S. Kitamura, T. Kitamura, K. Shibata, Y. Mizukami, S. Mukawa, and J. Nagakawa: ISIJ Int., 1991, vol. 31, pp. 1322-28.

309. A. Harada, G. Miyano, N. Maruoka, H. Shibata, and S. Kitamura: ISIJ Int., 2014, vol. 54, pp. 2230-38.

310. C. Liu, F. Huang, J. Suo, and X. Wang: Metall. Mater. Trans. B, 2016, vol. 47B, pp. 989-98.

311. S. Asai and J. Szekely: Metall. Trans., 1974, vol. 5, pp. 651-57.

312. J. Szekely and S. Asai: Metall. Trans., 1974, vol. 5, pp. 1573-80.

313. Y. Hsieh, Y. Watanabe, S. Asai, and I. Muchi: Tetsu-to-Hagané, 1983, vol. 69, pp. 596-603.

314. R. Ding, B. Blanpain, P.T. Jones, and P. Wollants: Metall. Mater. Trans. B, 2000, vol. 31B, pp. 197-206.

315. M.A. Van Ende, Y.M. Kim, M.K. Cho, J. Choi, and I.H. Jung: Metall. Mater. Trans. B, 2011, vol. 42B, pp. 477-89.

316. M.A. Van Ende and I.H. Jung: ISIJ Int., 2014, vol. 54, pp. 489 95.

317. M.A. Van Ende and I.H. Jung: Metall. Mater. Trans. B, 2017, vol. 48B, pp. 28-36.

318. S.P.T. Piva, D. Kumar, and P.C. Pistorius: Metall. Mater. Trans. $B, 2017$, vol. 48B, pp. 37-45.

319. D. Kumar and P.C. Pistorius: Metall. Mater. Trans. B, 2019, vol. 50B, pp. 181-91.

320. K. Beskow, J. Jia, C.H.P. Lupis, and S. Du: Ironmak. Steelmak., 2002, vol. 29, pp. 427-35.

321. N.N. Tripathi, M. Nzotta, A. Sandberg, and S. Du: Ironmak. Steelmak., 2004, vol. 31, pp. 235-40.

322. K. Beskow and S. Du: Ironmak. Steelmak., 2004, vol. 31, pp. $393-400$.

323. S. Riaz, K.C. Mills, and K. Bain: Ironmak. Steelmak., 2002, vol. 29 , pp. 107-13.

324. G.J. Hassall, K.G. Bain, N. Jones, and M.O. Warman: Ironmak. Steelmak., 2002, vol. 29, pp. 383-89.
325. Q. Shu, O. Volkova, and P.R. Scheller: Proc. Int. Symp. on Highly Innovative Novel Operations "Future Steelmaking Metallurgy," Iron and Steel Institute of Japan, Tokyo, 2010, pp. 106-15.

326. P.R. Scheller and Q. Shu: Steel Res. Int., 2014, vol. 85, pp. 131016.

327. O. Levenspiel: Chemical Reaction Engineering, Wiley, New York, NY, 1972.

328. J. Pietzka, E. Steinmetz, and H. Wilhelmi: Steel Res., 1987, vol. 12 , pp. $538-46$.

329. G.G.K. Murthy: ISIJ Int., 1989, vol. 29, pp. 49-57.

330. T.S. Kim, L. Holappa, and J.H. Park: Ironmak. Steelmak., 2020, vol. 47, pp. 84-92.

331. S. Feichtinger, S.K. Michelic, Y.B. Kang, and C. Bernhard: $J$. Am. Ceram. Soc., 2014, vol. 97, pp. 316-25.

332. T.S. Kim, Y. Chung, L. Holappa, and J.H. Park: Metall. Mater. Trans. B, 2017, vol. 48B, pp. 1736-47.

333. Y. Ren, L. Zhang, and Y. Zhang: J. Iron Steel Res. Int., 2018, vol. 25 , pp. 146-56.

334. D.C. Park, I.H. Jung, P.C.H. Rhee, and H.G. Lee: ISIJ Int., 2004, vol. 44, pp. 1669-78.

335. P. Ni, T. Tanaka, M. Suzuki, M. Nakamoto, and P.G. Jönsson: ISIJ Int., 2018, vol. 58, pp. 1979-88.

336. P. Ni, T. Tanaka, M. Suzuki, M. Nakamoto, and P.G. Jönsson: ISIJ Int., 2019, vol. 59, pp. 737-48.

337. C. Xuan, A. Karasev, P.G. Jönsson, and K. Nakajima: Steel Res. Int., 2017, vol. 88, art. no. 1600090 .

338. N. Kojola, S. Ekerot, M. Andersson, and P.G. Jönsson: Ironmak. Steelmak., 2011, vol. 38, pp. 1-11.

339. W. Tiekink, R. Boom, A. Overbosch, R. Kooter, and S. Sridhar: Ironmak. Steelmak., 2010, vol. 37, pp. 488-95.

340. M.A. Van Ende, M. Guo, B. Blanpain, and P. Wollants: Front. Mater. Sci., 2011, vol. 5, pp. 69-76.

341. G. Urbain: Steel Res., 1987, vol. 58, pp. 111-16.

342. K. Mukai: ISIJ Int., 1992, vol. 32, pp. 19-25.

343. K.C. Mills: ISIJ Int., 1993, vol. 33, pp. 148-55.

344. W.E. Lee and S. Zhang: Int. Mater. Rev., 1999, vol. 44, pp. 77104.

345. S. Zhang and W.E. Lee: Int. Mater. Rev., 2000, vol. 45, pp. 4158.

346. S. Wright, L. Zhang, S. Sun, and S. Jahanshahi: Metall. Mater. Trans. B, 2000, vol. 31B, pp. 97-104.

347. S. Sukenaga, N. Saito, K. Kawakami, and K. Nakashima: ISIJ Int., 2006, vol. 46, pp. 352-58.

348. J.H. Park: J. Am. Ceram. Soc., 2006, vol. 89, pp. 608-15.

349. J.H. Park: Calphad, 2007, vol. 31, pp. 149-54.

350. J. Liu, M. Guo, P.T. Jones, F. Verhaeghe, B. Blanpain, and P. Wollants: J. Eur. Ceram. Soc., 2007, vol. 27, pp. 1961-72.

351. J.H. Park: Calphad, 2007, vol. 31, pp. 428-37.

352. A. Shankar, M. Gornerup, A.K. Lahiri, and S. Seetharaman: Metall. Mater. Trans. B, 2007, vol. 38B, pp. 911-15.

353. J.H. Park and D.J. Min: ISIJ Int., 2007, vol. 47, pp. 1368-69.

354. J.H. Park, I.H. Jung, and S.B. Lee: Met. Mater. Int., 2009, vol. 15 , pp. $677-81$.

355. J.H. Park: Met. Mater. Int., 2010, vol. 16, pp. 987-92.

356. H. Kim, W.H. Kim, I. Sohn, and D.J. Min: Steel Res. Int., 2010, vol. 81, pp. 261-64.

357. J.H. Park, M.O. Suk, I.H. Jung, M. Guo, and B. Blanpain: Steel Res. Int., 2010, vol. 81, pp. 860-68.

358. H. Kim and I. Sohn: ISIJ Int., 2011, vol. 51, pp. 1-8.

359. Y.B. Kang and J.H. Park: Metall. Mater. Trans. B, 2011, vol. 42B, pp. 1211-17.

360. I. Sohn and D.J. Min: Steel Res. Int., 2012, vol. 83, pp. 611-30. 361. J.H. Park: J. Non-Cryst. Solids, 2012, vol. 358, pp. 3096-3102.

362. J.H. Park: Met. Mater. Int., 2013, vol. 19, pp. 577-84.

Publisher's Note Springer Nature remains neutral with regard to jurisdictional claims in published maps and institutional affiliations. 